EFEITOS DO USO CONTÍNUO DE HERBICIDAS SOBRE FUNGOS MICORRÍZICOS VESÍCULO-ARBUSCULARES EM CITROS, E NA ATIVIDADE MICROBIANA DO SOLO

\title{
ADELINO PEUSSARI
}

Engenheiro Agrônomo

Orientador: Prof. Dr. RICARDO VICTÓRIA FILHO

Tese apresentada à Escola Superior de Agricultura "Luiz de Queiroz", da Universidade de Sāo Paulo, para obtençāo do título de Doutor em Agronomia, Área de Concentraçāo: Solos e Nutriçāo de Plantas.

PIRACICABA

Estado de Sāo Paulo - Brasil

Abril - 1992 
Ficha catalográfica preparada pela seção de Livros da Divisão.de Biblioteca e Documentação - PCAP/USP

Pelissari, Adelino

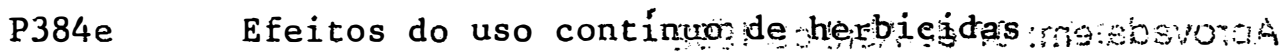
sobre fungos micorrízicos vesículo-arbusculares em citros, e na atividade microbiana do solo. P象 racicaba, 1992.

$147 \mathrm{p}$.

$\therefore$ Tese - ESALQ

B... Bibliografiags

1. Herbicida em laranja - Efeito xesidualj2. La ranja - Planta daninha - Controle 3. Micorriza - E

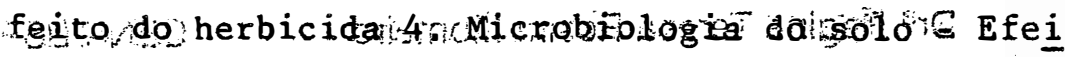
to do herbicida 5. Planta daninha - Controle I. Es cola Superior de Agricultura Luiz de Queiroz, Pirá cicaba 
Ofereço

A DEUS

Por ter-me usado como sua ferramenta.

Aos meus pais, meus primeiros MESTRES Orlando e Maria Lourdes Minha Homenagem

A minha esposa Isilda Aos meus filhos Alan, Mônica, Carla e Leticia.

DEDICO. 


\section{AGRADECIMENTOS}

Desejo expressar os meus sinceros agradécimentos a todos os que direta ou indiretamente colaboraram na realização do presente estudo, e em especial, às seguintes pessoas e instituiçōes:

Ao Curso de Pós-Graduaçāo em Agronomia - Área de Concentraçāo: Solos e Nutriçāo de Plantas, da Escola Superior de Agricultura "Luiz de Queiroz" da Universidade de São Paulo, pelo acolhimento possibilitando a realização do presente trabalho;

Ao Professor Doutor Ricardo Victória Filho, pelo estímulo, amizade, confiança, dedicaçāo e valorosa orientaçāo, minha eterna gratidāo;

Aos Pesquisadores Paulo Marcos da Silva, Roberto Bonetti e Rosángela Navarro do CENA - Centro de Energia Nuclear na Agricultura - Laboratório de Microbiologia do Solo, pela amizade e inestimável ajuda na realização da pesquisa;

Aos Professores Dr. Paulo Leonel Libardi do Departamento de Física e meteorologia e Dr. Durval Dourado Neto do Departamento de Agricultura pela amizade, colaboração e apoio;

Ao Professor Paulo Afonso Bracarense Costa do Departamento de Estatística da UFPR, pela amizade, dedicação e auxílios valiosos prestados;

A Professora Maria de Lourdes Pelissari Negreiros, pela colaboração e valioso auxílio na correçāo da linguagem;

Ao Professor Anibal de Moraes do Departamento de Fitotecnia e Fitossanitarismo pelas sugestōes oportunas; 
Ao Professor Edilberto Possamai do Departamento de Fitotecnia e Fitossanitarismo, pela amizade, e auxílios valiosos prestados;

A Coordenaçāo de Aperfeiçoamento de Péssoal de Nivel Superior - CAPES, pela concessão de Bolsa de Estudo;

A Fazenda Sete Lagoas Agrícola S.A., pelas facilidades concedidas à conduçāo do ensaio de campo;

Aos funcionários do Setor de Horticultura na pessoa do Sr. Luiz Ferrari, pelo auxilio na coleta dos dados;

Ao Dr. Roberto Abia Fernandez, pela amizade e agradecida colaboraçāo;

Aos amigos de Piracicaba nas pessoas dos Senhores Lino Di Piero, Murilo Melo, Miguel C. Carvalho, Paulo R. C. Castro e Luiz Campassi Junior, a minha eterna amizade e gratidāo;

Ao Professor Miguel António Loyola da Rocha, do Departamento de Fitotecnia e Fitossanitarismo da UFPR pelo incentivo e ajuda incondicional;

Aos companheiros mais próximos de curso Robinson Osipe; Austrelino Silveira Filho; Jorge Luiz Sales; Márcio Bastos Gomide; Eduardo Bernardo Luchese e Elmar Luiz Floss pela amizade e alegria da nossa convivência. 
ÍNDICE

LISTA DE FIGURAS .......................... viii

LISTA DE TABELAS ............................... ix

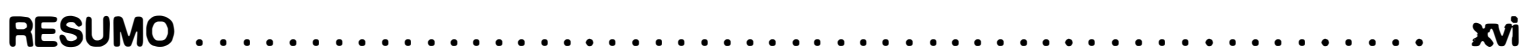

SUMMARY ............................. xvii

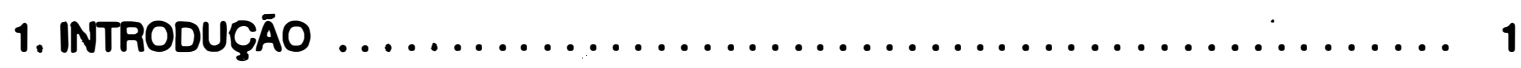

2. REVISĀO DE LITERATURA .......................... 3

2.1. Biologia das plantas daninhas $\ldots \ldots \ldots \ldots \ldots \ldots \ldots \ldots \ldots$

2.2. Matocompetiçāo ................................ 6

2.3. Medidas de controle vs fungos micorrizicos vesículos-arbusculares . . . . 6

2.4. Efeito dos herbicidas no desenvolvimento das plantas de citros . . . . . . 10

2.5. Importância dos fungos MVA nas plantas . . . . . . . . . . . . . . . . 14

2.6. Fatores que influenciam as micorrizas . . . . . . . . . . . . . . 21

2.6.1. Disponibilidade de nutrientes .................... 21

2.6.2. pH do solo . . . . . . . . . . . . . . . . . . . . . . . . . . . . . 24

2.6.3. Características físicas do solo . . . . . . . . . . . . . . . . . . . . . 26

2.6.4. Luz e Temperatura . . . . . . . . . . . . . . . . . . . . 27

2.6.5. Matéria orgânica ... . . . . . . . . . . . . . . . . . . . 28

2.6.6. Microbiota e Fauna . . . . . . . . . . . . . . . . . . . . . 29

2.6.7. Flutuação sazonal $\ldots \ldots \ldots \ldots \ldots \ldots \ldots \ldots \ldots \ldots \ldots \ldots \ldots$

2.7. Efeito dos herbicidas sobre os fungos MVA. . . . . . . . . . . . . . . 33

2.8. Efeito dos microrganismos sobre os herbicidas aplicados ao solo. . . . . . 36

2.9. Efeitos dos herbicidas sobre os microrganismos do solo . . . . . . . . . 41

2.9.1 Efeitos sobre bactérias, fungos e actinomicetos . . . . . . . . . . . . . 41

2.9.2. Efeitos na amonificaçāo e nitrificaçāo . . . . . . . . . . . . . . . . 47

2.9.3. Efeitos na denitrificaçāo ... . . . . . . . . . . . . . . . . . 49

2.9.4. Efeitos nos fixadores de nitrogênio . . . . . . . . . . . . . . . 50

2.9.5. Efeitos nas algas do solo . . . . . . . . . . . . . . . . . . . . 52

2.10. Efeito dos herbicidas na evoluçāo do $\mathrm{CO}_{2}$ do Solo . . . . . . . . . . . . . 53

3. MATERIAL E MÉTODOS ........................... 56

3.1. Local do Experimento e Características Edafo-climáticas . . . . . . . . . . 56

3.2. Cultivar ................................ 57

3.3. Herbicidas utilizados $\ldots \ldots \ldots \ldots \ldots \ldots \ldots \ldots \ldots \ldots$

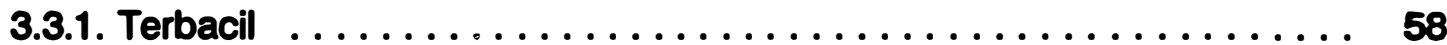

3.3.2. Simazine . . . . . . . . . . . . . . . . . . . . . . . . . . . 59

3.3.3. Dichlobenil . . . . . . . . . . . . . . . . . . . . . . . 60

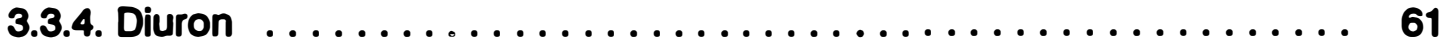

3.3.5. Bromacil ................................. 61 
3.3.6. Bromacil + Diuron $\ldots \ldots \ldots \ldots \ldots \ldots \ldots \ldots \ldots \ldots \ldots \ldots \ldots \ldots 6$

3.4. Delineamento experimental ...................... 63

3.5. Instalaçāo e condução dos experimentos de campo e laboratório ..... 64

3.5.1. Aplicação dos herbicidas ..................... 64

3.5.2. Coletas de amostras . . . . . . . . . . . . . . . . . . . . 64

3.5.3. Preparo das amostras $\ldots \ldots \ldots \ldots \ldots \ldots \ldots \ldots \ldots \ldots \ldots 6 . \ldots \ldots$

3.6. Metodologia Analítica ........................ 66

3.6.1. Atividade da microflora heterotrófica do solo ............. 66

3.6.2. Colonizaçāo micorrizica MVA .................... 67

3.6.3. Quantificação da população de esporos MVA. . . . . . . . . . . 68

3.6.4. Teores de Fósforo. . . . . . . . . . . . . . . . . . . . 69

3.7. Metodologia Estatística ....................... 69

4. RESULTADOS E DISCUSSÃO $\ldots \ldots \ldots \ldots \ldots \ldots \ldots \ldots \ldots \ldots \ldots$

4.1. Teores de fósforo ........................ 72

4.2. Colonizaçāo micorrízica MVA .................... 75

4.3. Quantificação da população de esporos MVA ............. 84

4.4. Atividade da microflora heterotrófica do solo ............... 88

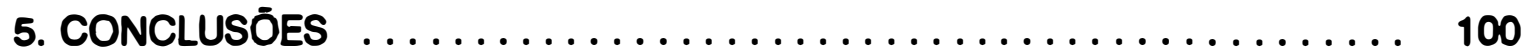

6. REFERÊNCIAS BIBLIOGRÁFICAS .................... 102

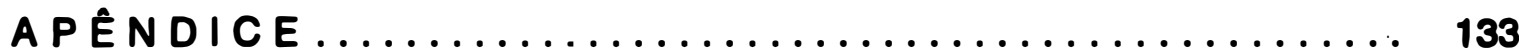




\section{LISTA DE FIGURAS}

Figura 1. Frasco radiorespirométrico

Figura 2. Diagrama de Venn ilustrativo na diferenciaçāo dos resultados ao nivel de $5 \%$ de significancia entre os tratamentos, para colonizaçāo micorrízica

Figura 3. Balanço hídrico mensal da Faz. Sete Lagoas - Conchal - SP 


\section{LISTA DE TABELAS}

Pág.

Tabela 1. Características químicas e fisicas do solo Latossol Vermelho Amarelo - Faz. Sete Lagoas - Conchal SP, 1977 e 1990.

Tabela 2. Tratamentos utilizados com as respectivas doses de ingrediente ativo (i.a.) e do produto comercial (p.c.) - Faz. Sete Lagoas - Conchal - SP, 1990.

Tabela 3. Épocas amostradas, material coletado e respectivas variáveis estudadas - Faz. Sete Lagoas - Conchal - SP, 1990.

Tabela 4. Teores de fósforo, em ppm, encontrados nos diferentes tratamentos para os tempos (1) e (2) Fazenda Sete Lagoas - Conchal - SP, 1990.

Tabela 5. Quadro da análise de variância para os teores de fósforo, média geral e coeficientes de variaçăo.

Tabela 6. Resultados da percentagem da colonização micorrizica MVA, por 10 seguimentos de raízes coradas com comprimento de $1 \mathrm{~cm}$, colocadas sobre lâminas, atribuindo-se notas de 0 (zero) a 100 (cem) - Fazenda Sete Lagoas - Conchal - SP, 1990.

Tabela 7. Teste de TUKEY para as média de tratamentos, sem considerar o tempo para colonização micorrizica VA. 
Tabela 8. Teste de TUKEY para as média de tratamento dentro do tempo 1 (antes da aplicaçāo), para colonizaçāo micorrízica VA.

Tabela 9. Teste de TUKEY para as média de tratamento dentro do tempo 2 (60 dias da aplicação), para colonizaçāo micorrizica VA.

Tabela 10. Teste de TUKEY para as média de tratamento dentro do tempo 3 (120 dias após aplicaçāo), para colonizaçāo micorrízica VA.

Tabela 11. Teste de TUKEY para médias de tempo, sem considerar os tratamentos para colonização micorrízica VA.

Tabela 12. Grupos de respostas pelo teste de TUKEY a 5\%, considerando-se 0 tempo dentro de cada tratamento para a colonização micorrízica VA.

Tabela 13. Resultado do número de esporos MVA, na regiāo de desenvolvimento das raízes de citros por $50 \mathrm{ml}$ de solo.

Tabela 14. Teste de TUKEY para médias de tempo, sem considerar os tratamentos, para número de esporos micorrízicos VA.

Tabela 15. Comparaçāo de médias dos tratamentos nos tempos estudados, para número de esporos MVA. 
Tabela 16. Atividade microbiana heterotrófica do solo, medida através da radiorespirometria; pela evoluçāo de $\mathrm{CO}_{2}$ liberado pelo consumo de $\mu \mathrm{mol}$ glicose por grama de solo fresco por hora - Fazenda Sete Lagoas - Conchal - SP, 1990.

Tabela 17. Teste de TUKEY para médias de tratamentos dentro do tempo 1 (antes da aplicaçāo), para atividade da microflora heterotrófica do solo.

Tabela 18. Teste de TUKEY para médias de tratamentos dentro do tempo 3 (30 dias após aplicaçāo), para atividade da microflora heterotrófica do solo.

Tabela 19. Teste de TUKEY para médias de tratamentos dentro do tempo 5 (120 dias após aplicaçāo), para atividade da microflora heterotrófica do solo.

Tabela 20. Teste de TUKEY para médias de tratamentos dentro do tempo 2 (2 dias após aplicaçāo), para atividade da microfiora heterotrófica do solo.

Tabela 21. Teste de TUKEY para médias de tratamentos dentro do tempo 4 (60 dias após aplicaçāo), para atividade da microflora heterotrófica do solo.

Tabela 22. Teste de TUKEY para médias de tempo sem considerar os tratamentos para atividade da microflora heterotrófica do solo.

Tabela 23. Grupos de respostas pelo teste de TUKEY a 5\%, considerando-se o tempo dentro de cada tratamento para atividade da microflora heterotrófica do solo. 
Tabela 24. Quadro da análise de variância para colonização micorrízica VA, média geral e coeficientes de variação.

Tabela 25. Teste de TUKEY para médias de tempo dentro do tratamento 1 do fator tratamento para colonização micorrizica.

Tabela 26. Teste de TUKEY para médias de tempo dentro do tratamento 2 do fator tratamento para colonização micorrizica.

Tabela 27. Teste de TUKEY para médias de tempo dentro do tratamento 3 do fator tratamento para colonização micorrízica.

Tabela 28. Teste de TUKEY para médias de tempo dentro do tratamento 4 do fator tratamento para colonização micorrízica.

Tabela 29. Teste de TUKEY para médias de tempo dentro do tratamento 5 do fator tratamento para colonização micorrizica.

Tabela 30. Teste de TUKEY para médias de tempo dentro do tratamento 6 do fator tratamento para colonização micorrízica.

Tabela 31. Teste de TUKEY para médias de tempo dentro do tratamento 7 do fator tratamento para colonização micorrízica.

Tabela 32. Teste de TUKEY para médias de tempo dentro do tratamento 8 do fator tratamento para colonização micorrizica. 
Tabela 33. Quadro da análise de variância para número de esporos MVA, média geral e coeficientes de variação.

Tabela 34. Teste de TUKEY para médias de tempo dentro do tratamento 1 do fator tratamento para número de esporos MVA.

Tabela 35. Teste de TUKEY para médias de tempo dentro do tratamento 2 do fator tratamento para número de esporos MVA.

Tabela 36. Teste de TUKEY para médias de tempo dentro do tratamento 3 do fator tratamento para número de esporos MVA.

Tabela 37. Teste de TUKEY para médias de tempo dentro do tratamento 4 do fator tratamento para número de esporos MVA.

Tabela 38. Teste de TUKEY para médias de tempo dentro do tratamento 5 do fator tratamento para número de esporos MVA.

Tabela 39. Teste de TUKEY para médias de tempo dentro do tratamento 6 do fator tratamento para número de esporos MVA.

Tabela 40. Teste de TUKEY para médias de tempo dentro do tratamento 7 do fator tratamento para número de esporos MVA.

Tabela 41. Teste de TUKEY para médias de tempo dentro do tratamento 8 do fator tratamento para número de esporos MVA. 
Tabela 42. Quadro da análise de variância para atividade da microflora heterotrófica do solo, média geral e coeficientes de variação.

Tabela 43. Teste de TUKEY para médias de tempo dentro do tratamento 1 do fator tratamento para atividade da microflora heterotrófica do solo.

Tabela 44. Teste de TUKEY para médias de tempo dentro do tratamento 2 do fator tratamento para atividade da microflora heterotrófica do solo.

Tabela 45. Teste de TUKEY para médias de tempo dentro do tratamento 3 do fator tratamento para atividade da microflora heterotrófica do solo.

Tabela 46. Teste de TUKEY para médias de tempo dentro do tratamento 4 do fator tratamento para atividade da microflora heterotrófica do solo.

Tabela 47. Teste de TUKEY para médias de tempo dentro do tratamento 5 do fator tratamento para atividade da microflora heterotrófica do solo.

Tabela 48. Teste de TUKEY para médias de tempo dentro do tratamento 6 do fator tratamento para atividade da microflora heterotrófica do solo.

Tabela 49. Teste de TUKEY para médias de tempo dentro do tratamento 7 do fator tratamento para atividade da microflora heterotrófica do solo.

Tabela 50. Teste de TUKEY para médias de tempo dentro do tratamento 8 do fator tratamento para atividade da microflora heterotrófica do solo. 
Tabela 51. Dados climáticos e balanço hídrico mensal, segundo THORNTHWAITE \& MATHER (1955), da Faz. Sete lagoas - Conchal-SP, Ano: 10/89 - 9/90 (CAD: 167,4 mm). 


\title{
EFEITOS DO USO CONTINUO DE HERBICIDAS SOBRE FUNGOS MICORRIZZICOS VESÍCULO-ARBUSCULARES EM CITROS, E NA ATIVIDADE MICROBIANA DO SOLO
}

\author{
Autor: ADELINO PELISSARI \\ Orientador: PROF. DR. RICARDO VICTORIA FILHO
}

RESUMO

A micorriza vesículo-arbuscular (MVA) exerce influência marcante sobre a nutrição e desenvolvimento das plantas de citros. A atividade microbiana heterotrófica do solo, por sua vez, é responsável pelas transformaçōes do material orgánico depositado sobre a superficie do solo ou incorporado ao mesmo, em diferentes fraçōes que compōem a matéria orgânica.

Considerando-se a importância que assumem os herbicidas na citricultura brasileira, avaliou-se neste trabalho o impacto provocado sobre a colonizaçāo micorrízica das raízes de citros, populaçāo de esporos na regiāo de desenvolvimento dessas raizes e na atividade microbiana heterotrófica do solo pelos herbicidas terbacil, simazine, dichlobenil, diuron, bromacil e bromacil + diuron.

Essas avaliaçōes foram feitas após 13 anos de aplicaçōes ininterruptas, com uma aplicação anual desses produtos, em pré-emergéncia, sempre no mesmo local.

0 experimento foi conduzido num delineamento de blocos casualizados com três repetiçōes, em Latossol Vermelho Amarelo no município de Conchal, SP, em laranjeira da cultivar Pera Citrus sinensis (L.) Osbeck, enxertados sobre limão "Cravo" Citrus limonia Osbeck.

Os resultados obtidos permitiram concluir que: a) após 13 anos, de aplicação anual desses herbicidas, 0 impacto provocado na colonização das raízes e na população de esporos do solo foi semelhante ao da capina manual; b) o efeito da capina manual na atividade microbiana heterotrófica do solo, foi superior ao apresentado pelos herbicidas, no entanto, nas condiçōes desse estudo, nāo ultrapassou o período de $\mathbf{3 0}$ dias; c) aplicaçōes de NPK em ótimas condiçōes de umidade, seguida de estiagem nos meses subsequentes, causaram a reduçāo da colonizaçāo das raízes, bem como propiciaram o aumento do número de esporos do solo; d) os herbicidas desse estudo atuaram como agentes moderadores ou estabilizadores da atividade microbiana heterotrófica do solo, apresentando niveis de evoluçāo de $\mathrm{CO}_{\mathbf{z}}$ semelhantes durante o período de estudo. 


\title{
EFFECT OF REPEATED FIELD APPLICATIONS OF HERBICIDES UNDER MYCORRHIZAL FUNGI VAM AND SOIL MICROBIAL ACTIVITY IN CITRUS ORCHARD
}

\author{
Author: ADELINO PELISSARI \\ Advisor: PROF. DR. RICARDO VICTÓRIA FILHO
}

\section{SUMMARY}

The vesicular-arbuscular mycorrhizes (VAM) plays an important role over citrus plant nutrition and development. The soil heterotrophical microbial activity, by itself, is responsible for transformations of vegetable material present on the soil surface or incorporated to it, resulting in different fractions that forms the organic matter.

Considering the importance of the herbicides are assuming in the Brazilian citriculture, this study evaluated the impact over mycorrhyzal colonization of citrus roots, spores population in the development region of it's roots and in the soil heterotrophical microbian activity caused by the herbicides terbacil, simazina, dechlobenil, diuron, bromacil e bromacil + diuron.

These evaluations were done after 13 years of continuos service with one annual application of these molecules in pre-emergence, always at the same area.

The experiment was conducted with three replications in a randomized complete blocks, in a Red Yellow Latossol in Conchal country, SP, cultivated with Pear orange cultivar, implanted over "Cravo" lemon.

The results obtained permitted to conclude: a) after 13 years, with one annual application of those herbicides, the impact installed in the root colonizations and soil spores population were similar to the manual clean out treatment; b) the effect os the manual clean out over the heterotrophical microbian activity of the soil were much superior to that presented by the herbicides, however, in the conditions of this study, did not extended over $\mathbf{3 0}$ days; c) NPK application in optimum humidity conditions followed by drying in the following months caused a reduction of root colonizations, as well as propitiated an increase in the spores number in the soil; d) the herbicides used in this study acted as moderated agents or stabilizers of soil heterotrophical microbian activity, presenting similar levels of $\mathrm{CO}_{\mathbf{2}}$ evolution during the period studied. 


\section{INTRODUÇÃO}

No Brasil, mais propriamente no Estado de São Paulo, a citricultura ocupa um lugar importante na obtençāo de divisas económicas.

Dentre os produtos de origem agricola que o país exporta, o suco concentrado de laranja e a própria fruta "in natura", ocasionaram na década passada, uma grande corrida para este setor da produção. Isto, devido aos bons preços recebidos pelos citricultores nas safras de 88/89 e 89/90 (NEVES, 1990).

Dada às boas cotaçōes do suco de laranja brasileiro no mercado internacional e o ótimo preço da fruta no mercado interno, a citricultura ocupou na safra 88/89 o primeiro lugar no valor bruto da produção do Estado de São Paulo, superando produtos como a cana-de-açúcar, o café e a carne bovina (NEVES, 1989).

O conceito de cultura rentável tem sido o resposável pela expansão dos pomares de laranja na regiāo centro-sul do país, sem contudo obedecer a um critério de crescimento planejado. Embora, diversos cientistas da área de economia agrícola têm alertado para o problema, as conseqũências deverão repercutir nos anos noventa, com perspectivas de superprodução, pelo menos durante a primeira metade desta década.

Diante de tal quadro, qual seria a alternativa? Este conceito de economia rentável, no entanto, deve ser embasado e suportado, pela pesquisa cientíica favorecendo a competência técnica no uso eficiente dos fatores de produção, e buscar no rendimento da cultura o suporte necessário à competitividade com os outros países produtores.

A utilização de herbicidas, constitui uma tecnologiausual nos pomares altamente tecnificados, como método de controle de plantas daninhas, evitando a 
matocompetição com a cultura da laranja, não permitindo a redução da produçāo. Entretanto, esta prática exige um conhecimento suficiente seu comportamento no solo e na planta, para que nāo ocorram desequilíbrios ambientais (NICTÓRIA FILHO, 1983). Neste sentido, poucos são os trabalhos realizados que procuram estudar os efeitos desses agroquímicos, a longo prazo, aplicados na agricultura.

Através da microbiologia do solo, são possíveis avaliaçōes que proporcionam uma melhor compreensāo dos efeitos desses herbicidas sobre fungos e bactérias benéficos à agricultura, que vivem em simbiose com as culturas ou atuam na transformação do material orgânico depositado no solo (ALEXANDER, 1977; MACLAREN, 1978; SKUJINS, 1978 e ATLAS \& BARTHA, 1981).

O presente trabalho tem por objetivo quantificar, através de variáveis microbiológicas, como: colonizaçāo de raízes por fungos MVA, número de esporos MVA na regiāo de desenvolvimento radicial do citros e atividade da microflora heterotrófica do solo, o efeito do uso contínuo de herbicidas residuais, aplicados na condução de pomares citricos a longo prazo num mesmo local. 


\section{REVISÃO DE LITERATURA}

A partir de 1962, verificou-se uma vigorosa expansāo na citricultura brasileira e em especial no Estado de São Paulo, (VICTÓRIA FILHO 1983), por ter início na mesma época, a fase de industrializaçāo da fruta de laranja e a produçāo do suco concentrado congelado.

Esta prática industrial, somada à perspectiva de bons lucros, fez do Brasil o maior produtor de frutas cítricas da América do Sul e o segundo produtor mundial (CAMPOS, 1976).

Do entusiasmo verificado na última década, à previsāo de tempos ruins para a década de 90, os pesquisadores das instituiçōes: Instituto Agronómico de Campinas, Instituto Biológico de Sāo Paulo, Escola Superior de Agricultura "Luiz de Queiroz" - USP, Faculdade de Ciências Agrárias e Veterinárias- UNESP - Jaboticabal, Faculdade de Ciências Agronómicas - UNESP - Botucatu e Estaçāo Experimental de Citricultura de Bebedouro, que trabalham em citricultura, reunidos em 18 de outubro de 1990, na Estaçāo Experimental Sylvio Moreira - Cordeirópolis - SP, analisaram as necessidades que tem essa atividade agrícola, para manter a grande importância que representa na economia brasileira.

Dessa reuniāo, elaborou-se um documento na forma de manifesto público, amplamente divulgado, o qual reune os pontos importantes a serem enfrentados tanto pelo governo, como pelo produtor e indústria, como segue:

a) Crescente necessidade de novas tecnologias para atender a grande expansāo do setor citrícola. 
b) Aumento de problemas limitantes à citricultura e o náo crescimento correspondente da ação de pesquisa.

c) Necessidade de medidas de salvaguarda da citricultura face aos graves problemas fitossanitários existentes ou potenciais.

d) Número insuficiente de pesquisadores atuando nas áreas citrícolas e falta de formação de novos pesquisadores ou equipes.

e) Necessidade imperativa de geração de conhecimentos e materiais locais, antecipando soluçóes e não adaptando tecnologia importada.

f) Escassez de recursos orçamentários alocados à pesquisa citrícolas decorrente de apoio insuficiente do governo e da iniciativa privada.

A situaçāo acima agrava-se, uma vez que, a pesquisa não pode parar, ao contrário precisa ser intensificada para se evitar possivel colapso do setor agroindustrial citrícola a médio prazo (MANIFESTO DOS PESQUISADORES EM CTRICULTURA DO ESTADO DE SĀO PAULO, 1990).'

Existem muitos pontos básicos que necessitam de respostas de trabalhos científicos, conduzidos em nossas condiçōes em relaçāo à competição, cultivo do solo, aplicaçāo de herbicidas, absorção, translocaçāo, mecanismo e modo de açāo, locais de acúmulo dentro da planta, seus efeitos sobre os microrganismos do solo, degradaçāo da mólécula original e de seus metabólitos, além dos resíduos no solo e no fruto colhido.

No Brasil há, portanto, necessidade de maior número de pesquisas na área de manejo do mato em citricultura (VICTÓRIA FILHO, 1983).

\subsection{Biologia das plantas daninhas}

Um dos pontos básicos para a utilizaçāo adequada de qualquer método de controle de plantas daninhas, é o conhecimento das mesmas com informaçōes sobre

'Manifesto dos pesquisadores em citricultura do Estado de São Paulo, Estação Experimental Sylvio Moreira, Cordeirópolis, SP, 1990. 
a biologia, época de ocorrência e danos produzidos às plantas de citros (VICTÓRIA FILHO, 1983).

A identificaçāo das plantas daninhas no campo constitui-se numa tarefa difícil, requerendo-se do técnico um bom conhecimento prático de identificação das plantas daninhas, quando elas se encontram ainda no estágio juvenil ou de plântula, isto é, antes que a competição da planta daninha com a cultura tenha se iniciado.

A identificação das principais plantas daninhas e o período de sua máxima capacidade competitiva, constituem estudos de importância fundamental para um posterior emprego racional do controle do mato (DURIGAN, 1982).

Para as nossas condiçōes, já existem alguns trabalhos relatando as principais plantas daninhas que ocorrem em pomares cítricos, onde a família Gramineae é tida como a mais importante, seguida das famílias Compositae, Malvaceae e Euphorbiaceae (RODRIGUEZ, 1969).

Num estudo mais detalhado por DONADIO et alii (1976), para identificação das principais espécies infestantes de pomares das três maiores regiōes produtoras de cítricos do Estado de São Paulo, a saber; Limeira, Bebedouro e Pariquera-Açu em três épocas: primavera-verāo (outubro a dezembro), outono (março a abril) e Inverno (julho,agosto) constatou-se que em regiōes de clima semelhante há diferenças na flora infestante, acentuando-se quando muda o clima. Verificou-se nas regiōes de Limeira e Bebedouro, a semelhança na ocorrência de algumas espécies de mato, ao passo que em Pariquera-Açu apareceram espécies que nāo foram encontradas nas outras regiōes.

Neste trabalho, observou-se também, que as diferenças maiores entre as espécies foram notadas nas entre-linhas e sob as copas das plantas cítricas. Para Bebedouro e Limeira, o período do outono foi de grande infestaçāo de mato e consequente competiçāo. Por outro lado, Pariquera-Açu requer atençāo no controle das plantas daninhas 0 ano todo.

Entre as comunidades de plantas daninhas das regiōes estudadas, algumas populaçōes de infestantes se caracterizaram por serem mais típicas em cada regiāo, como se observou para o capim carrapicho Cenchrus echinatus $L$ e poaia-branca Richardia brasilienses Gomez em Bebedouro; mentrasto Ageratum conyzoides L e 
vernonia Vemonia scorpioides Lam. Pers. em Pariquera-Açu e a nabiça Raphanus raphanistrum L em Limeira.

\subsection{Matocompetiçăo}

As plantas daninhas interferem com as culturas por água, luz e nutrientes.

Os prejuizos causados pelas plantas daninhas às culturas agricolas tropicais, situam-se ao redor de 30 a $50 \%$ evidenciando-se que uma populaçāo natural de plantas daninhas, se considerada isoladamente, pode causar prejuizos acima de $80 \%$ chegando a anular completamente a produçāo (IAPAR, 1976).

Trabalhos brasileiros que tratam de competiçāo das plantas daninhas em diversas culturas, permitem a elaboração de tabelas sobre as épocas em que ocorrem essa competiçāo, ou seja, sobre o período de competiçāo (BLANCO, 1982).

A cultura da laranja, pode apresentar perdas por interferência com as plantas daninhas em $40 \%$ no número de frutos, sendo este período de dezembro a março ou de agosto a novembro, período em que a cultura deve estar livre da interferéncia do mato (BLANCO, 1982). Todavia, próximo das plantas cultivadas o controle das plantas daninhas deve ser feito durante todo o ano (VICTÓRIA FILHO, 1983).

\subsection{Medidas de controle vs fungos micorrizicos vesiculos-arbusculares}

Os métodos de controle de plantas daninhas empregados na citricultura são os mais diversos.

A meta primária de qualquer sistema de manejo de plantas daninhas é a manutenção de um ambiente o mais inóspito possivel ao mato através do emprego especifico ou combinado de métodos biológicos, culturais, mecânicos e químicos, os quais devem frequentemente ser revistos e, se necessário, reformulados por se tratar de um processo extremamente dinâmico (PTELLI, 1982).

Segundo o mesmo autor, na atualidade, a integração das medidas de controle se intensificam entre os produtores, onde procura-se utilizar um conjunto de medidas que integradas apresentam grande efeito sobre a espécie ou as espécies daninhas, 
cujo controle é desejado naquele momento. Esclarecendo, que este processo envolve todo um contexto em termos de planejamento global de utilizaçāo da área e da integraçáo desta com outras áreas, dentro da propriedade agrícola ou mesmo da região na qual se insere, visando um equilibrio com outras medidas de manejo de solos e demais práticas agrícolas e uma compatibilização ambiental e económica.

Aproveitando da experiéncia de vários autores que trabalham no controle de plantas daninhas, DURIGAN (1982), propóe uma opçāo para o controle integrado do mato em pomares de citros:

a) aplicação de um herbicida ao solo, com efeito residual e que seja seletivo às plantas de interesse económico, em uma faixa de 1 a 2 metros de largura ao lado de cada fileira de plantas;

b) plantio de leguminosas, nas entre linhas, no inicio das chuvas, náo permitindo o desenvolvimento das plantas daninhas. Tais leguminosas poderão se constituir em refúgio de pragas e de predadores de pragas de citros; ou então,

c) manter o espaço preenchido pelas plantas daninhas entre as faixas tratadas com herbicidas residuais sempre ceifado, no caso de não serem plantadas leguminosas, durante o periodo das águas;

d) destruir mecánica ou quimicamente toda leguminosa ou plantas daninhas que ocorrem nas entre linhas, no final das águas e inicio da seca.

Uma série de consideraçóes acerca do controle das plantas daninhas em fruticultura são apresentadas por diversos pesquisadores a respeito da necessidade de um maior número de trabalhos científicos na elucidaçāo de um conjunto de problemas, sobre os efeitos que os diferentes métodos de controle exercem sobre o ambiente $e$ nos processos fisiológicos da planta cultivada (SILVA \& ROMAM, 1978; FORSTER, 1979).

Dentre as relaçōes harmónicas que existem na natureza, uma que deve ser melhor entendida, é a simbiose entre as raízes dos citros e os fungos micorrizicos vesículo-arbusculares. 
Os efeitos das micorrizas no crescimento e sobrevivência das plantas estāo amplamente documentados, destacando-se a melhor nutrição principalmente de fósforo, que é provocada pela simbiose planta-fungo MVA, resultando no melhor desenvolvimento dos vegetais (GERDEMANN, 1968; MOSSE, 1973; TINKER, 1975; SIQUEIRA \& FRANCO, 1988 e CARDOSO, 1990).

A intensidade de cultivo, práticas de adubação e calagem, monocultura, rotação de culturas, controle da erosão do solo e uso de defensivos agricolas, são fatores de grande importância para a ecologia das micorrizas.

As araçōes pouco profundas $e$ as adubaçóes mais leves favorecem o estabelecimento das micorrizas, enquanto as adubaçóes pesadas, monocultura com culturas anuais e o uso indiscriminado de defensivos, principalmente os fungicidas sistémicos e fertilizantes, reduzem a incidência de micorrizas (SIQUEIRA \& FRANCO, 1988).

Citam os referidos autores que as preocupaçōes crescentes com a qualidade do meio ambiente, a elevação nos custos dos insumos e a necessidade de se aumentar a produçāo de alimentos, fibras e madeira, têm despertado grande interesse dos cientistas, agricultores e setores do mercado de tecnologia, pelos fungos micorrizicos. Isso estimulou um grande volume de pesquisas, que, nas últimas três décadas, evidenciaram a natureza e magnitude desses efeitos, bem como as potencialidades para a exploração das micorrizas nos sistemas de produção, desde aqueles de subsisténcia, até os mais tecnificados do mundo.

Entretanto, o cultivo do solo com o objetivo de controlar as plantas daninhas através de capina manual, capina com traçāo animal ou tratorizada se constitui no método de controle mais utilizado entre os citricultores (IAPAR, 1976). Estes métodos ainda que eficientes para o controle das plantas daninhas são responsáveis por grandes prejuizos, tanto nas plantas de citros, por provocar ferimentos nos caules e cortes nos sistemas radiculares superficiais, constituindo-se em locais para a entrada de microrganismos patogénicos, como pela desestruturação dos agregados do solo favorecendo a erosão e a sua degradaçáo.

Tanto que, atribui-se a degradaçāo do solo principalmente em climas tropicais ao cultivo, que somada às altas temperaturas e umidade favorecem a atividade 
microbiana o que resulta numa alta degradaçāo da matéria orgânica, bem como num declínio da sua estrutura (MARTEL \& PAUL, 1970).

Pouco se sabe, no entanto, sobre a influência do manejo do solo, na simbiose entre as raizes das plantas de citros com os fungos MVA.

Em solos cultivados com enxadas rotativas, o número de esporos tende a diminuir quando comparados com solos arados superficialmente ou até mesmo aqueles nāo cultivados (KRUCKELMANN, 1975).

KUCEY \& PAUL (1983), verificaram que o cultivo do solo altera os parámetros abióticos, que por sua vez afetam os componentes bióticos, tornando-se desta maneira fácil de compreender, segundo os autores, que toda prática que reduz a densidade e - potencial das raízes do hospedeiro, também, reduz o número de esporos encontrados no solo.

A utilização de herbicidas para o controle das plantas daninhas, é uma prática bastante difundida em diversas regiōes citrícolas do mundo, como os Estados Unidos da América do Norte tratando de cerca de 50\% de sua área total, (LANGE et alii, 1975), sendo que na califórnia, cerca de $75 \%$ da área de citros irrigada é tratada com herbicidas (KASASIAN, 1971).

Os trabalhos que discutem os efeitos dos herbicidas sobre a associação simbiótica MVA com plantas de citros sāo reduzidos. O controle de plantas daninhas com herbicidas é citado como a provável causa da auséncia de Gigaspora margarita nos pomares da Califórnia. Entretanto, este fato nāo se verifica na Flórida, atribuindo-se a presença do fungo neste Estado, em parte, as plantas daninhas as quais sāo comuns em seus pomares, o que nāo ocorre nos pomares da califórnia (NEMEC et alii, 1981).

No Brasil, a utilizaçāo de herbicidas está condicionada às grandes empresas citrícolas e algumas melhores tecnificadas NICTÓRIA FILHO, 1983). A área tratada nāo atinge mais que 5-10\% da área plantada (PRATES, 1980 e CAETANO, 1980).

Nas condiçōes do Estado de Sāo Paulo, nāo se detectou diferenças significativas entre o tratamento controle e os tratamentos com herbicidas, para número de esporos por grama de solo e índice de colonizaçāo por fungo MVA em raizes de citros (SANTOS, 1989). 


\subsection{Efelto dos herbicidas no desenvolvimento das plantas de citros}

Os herbicidas contribuem sobremaneira para a manutençāo da produção agricola, liberando a cultura da interferência das plantas daninhas.

A açāo desses herbicidas, não limita-se tão somente ao objetivo imediato de matar ou nāo permitir a germinaçāo de uma determinada espécie de planta daninha. Tem-se relatado o efeito dos mesmos no desenvolvimento das culturas.

Esses efeitos são apresentados por muitos pesquisadores através de avaliaçōes visuais de fitotoxicidade, não permitindo assim uma análise mais pormenorizada dos mesmos.

Poucos sāo os trabalhos na literatura que tratam com profundidade os efeitos de aplicaçōes anuais repetidas no desenvolvimento das plantas de citros (VICTÓRIA FILHO, 1983).

Estudos básicos para se verificar os efeitos fisiologicos dos herbicidas nas plantas de citros, têm sido conduzidos. Assim, GOREM \& MONSELISE (1966), em Israel, verificaram o efeito da simazine e atrazine nas doses de 0,90; 1,34 e 1,79 $\mathrm{Kg}$ i.a./ha em mistura com amitrole a 2,69; 3,58 e 4,48 $\mathrm{kg}$ i.a./ha, em plantas de laranja "Shamouti", com um ano após plantio, tendo como porta-enxertos laranja "Doce" e laranja "Azeda". Nos solos pesados os sintomas de fitotoxicidade com atrazine apareceram cerca de 6 meses após um periodo quente e seco. As folhas tornaram-se bronzeadas e secas, o crescimento paralizou, o peso seco, a clorofila e a atividade da catalase das folhas diminuiram, e a atividade da peroxidase aumentou, quando comparado com a testemunha. No entanto, a simazine, ao contrário, aumentou o crescimento, nitrogénio total e proteico, e a clorofila nas folhas. Nāo afetou a peroxidase, catalase e Ácido ascórbico, porém, diminuiu levemente o peso seco.

Também, o fluometuron, em Israel, aplicado em doses de até $80 \mathrm{~kg}$ i.a./ha em plantas adultas de laranja "Pera", e de 16 kg i.a./ha em plantas jovens de laranja "Azeda", nāo teve influência na fotossíntese, respiraçāo, peso seco e conteúdo de clorofila nas folhas. Os dados de laboratório mostraram que os citros podem ser considerados resistentes ao fluometuron, e que a falta de translocação das raízes para 
a parte aérea, assim como a demetilaçāo, sāo as causas da seletividade (GOREN, 1969).

No Brasil, dentre os trabalhos realizados com o objetivo de se verificar o efeito dos herbicidas no desenvolvimento das plantas de citros, está o conduzido por VICTÓRIA FILHO (1983). Nesse trabalho, com dois experimentos conduzidos a longo prazo, um em Jaboticabal-SP, utilizando-se plantas do cultivar Natal, e o outro em Conchal-SP com plantas do cultivar Pera, ambos cultivares enxertados sobre limão "Cravo", foram realizadas amostragens em doze épocas, por um período de 6 anos, sempre nos meses de março e outubro.

O experimento de Jaboticabal recebeu uma aplicação anual de herbicida sendo a primeira realizada quando o pomar já apresentava um certo desenvolvimento, isto é, com cerca de 4 anos após o plantio no campo. Os herbicidas utilizados neste experimento em $\mathrm{kg}$ i.a./ha foram: fluometuron 4,2; simazine 4,8; atrazine 4,8; bromacil 3,2; bromacil + diuron (Krovar I) 4,8; bromacil + diuron (Krovar II) 4,8; terbacil 3,2; oxadiazon 1,5; dichlobenil 3,0 e 6,0 kg i.a./ha.

O experimento de Conchal, recebeu também uma aplicação anual de herbicida, sendo que a primeira foi realizada estando o pomar com 2 anos de plantio no campo. Os herbicidas utilizados neste experimento em kg i.a./ha foram: terbacil 3,2; simazine 4,0; ametrine + secbumetone 4,5; dichlobenil 5,0; diuron 3,2; bromacil 3,2; bromacil+diuron 3,2; paraquat 0,6; glifosate 1,61 e MSMA 1,77 kg i.a./ha.

Para o experimento de Jaboticabal, observou 0 autor que 0 diâmetro perpendicular do caule, diâmetro paralelo do caule e altura de plantas não apresentou diferença estatística entre os tratamentos, bem como não se observou efeitos fitotóxicos a não ser alguma clorose foliar nos últimos anos em alguns tratamentos, porém, de difícil identificaçāo, uma vez que também ocorreram em algumas parcelas da testemunha.

Semelhança se verificou na Califórnia, EUA, com doses altas desses herbicidas residuais em citros, sendo considerado difícil de ser distinguido de anormalidades devido a outras causas como: problemas de nutriçāo, doenças e problemas de água e solo (JORDAN et alii, 1969). 
No experimento conduzido em Conchal, notou-se com relaçāo ao diâmetro perpendicular do caule, diâmetro perpendicular da copa e diâmetro paralelo da copa, que nāo houve diferença estatística entre os diferentes tratamentos utilizados.

Por outro lado, o parâmetro diâmetro paralelo do caule, apresentou valores para o teste de $\mathrm{F}$ significativos ao nivel de $5 \%$, na $9^{a}$ e $11^{a}$ mediçóes; todavia, quando se aplicou o teste de TUKEY, nāo foi notado diferença entre os tratamentos, devido estas diferenças terem provavelmente ocorrido muito próximos dos valores de significáncia. Ainda, a altura de plantas mostrou diferença entre os tratamentos na $4^{a}$ época quando o tratamento com simazine e apresentou-se com menor valor, e bromacil + diuron com maior valor. A explicaçāo dada para este fato, segundo o autor foi que nos anos de 1977 e 1978, pelos dados de controle das plantas daninhas, verificou-se que 0 tratamento com simazine nāo apresentou um controle satisfatório das plantas daninhas, principalmente de gramíneas, naqueles anos, o que pode ter contribuido para um menor desenvolvimento daquelas plantas. Contudo, nos anos seguintes nāo se verificou diferenças estatísticas entre os tratamentos, muito embora o tratamento com simazine tenha permanecido com altura menor que os demais tratamentos.

Durante todo o transcorrer do ensaio de Conchal, nāo se verificou efeitos fitotóxicos visuais às plantas de citros.

Concordando com os resultados obtidos em Conchal, na ttália, tem-se observado que os herbicidas diuron, simazine, paraquat, diquat, bromacil e terbacil nāo apresentaram resíduos a ponto de afetar o crescimento ou mesmo de apresentar sintomas de fitotoxicidade às plantas de citros (TORRISI, 1969).

Trabalhos realizados em Cuba, por PEREZ (1976), com os herbicidas fluometuron, monuron, simazine e bromacil, e em Araras-SP por CRUZ et alii (1978), com secbumetone, ametrine + atrazine, secbumetone + ametrine, terbutilazine + terbumetone, bromacil, terbacil e simazine + ametrine num experimento conduzido por 4 anos, nāo se verificou influência no desenvolvimento e produçāo das plantas de citros.

Também, bons resultados tanto no crescimento da planta como na produçāo de citros, se observou na Flórida, EUA, e na Espanha. Atribuindo-se a estes bons resultados, um melhor controle das plantas daninhas e uma menor injúria às raizes da 
cultura pelo uso de determinados herbicidas quando comparados ao sistema convencional de controle do mato (MILELLA \& DEIDDA, 1973; RYAN, 1969). Por outro lado, em Cuba, PEREZ (1976) quando se aplicou atrazine na dose de 4,8 $\mathrm{kg}$ do i.a./ha por trés vezes ao ano, em um pomar de laranja "Valéncia", apresentou efeito depressivo no diâmetro do tronco, cerca de $18 \%$ menor que a testemunha.

Com relação aos sintomas visuais de fitotoxicidade, diversos pesquisadores nāo encontraram efeitos em plantas de citros nas mais diversas condiçōes ecológicas como é o caso de RODRIGUEZ (1960), com diuron; MOREIRA e DONADIO (1968 e 1969), com diuron, fluometuron e simazine; VIEIRA et alii (1973) com bromacil + diuron, diuron e simazine; PRATES et alii (1980) com MSMA e glifosate; GREGORY e ROESSING (1964), com bromacil e diuron; DONADIO of alii (1971), com terbacil e paraquat; ORTUÑo et alii (1973), com simazine, fluometuron, bromacil e bromacil + diuron; FONTES et alii (1979), com bromacil + diuron e diuron e POMPEU et alii (1980), com diuron, MSMA e bromacil + diuron.

Em paises onde o controle das plantas daninhas com herbicidas é mais frequente, pequenas sāo as influências no desenvolvimento e produtividade das plantas de citros pelos principais herbicidas aplicados nesta cultura (JORDAN et alii, 1969; RYAN, 1969; GOREN \& MONSELISE, 1969 e TORRISI, 1969. Ainda, há citaçāo onde se mostra vantagens em termos de produçāo para o controle químico, atribuindo-se ao melhor controle das plantas daninhas, quando comparado com os diversos tipos de manejo do solo (HERBOLDT, 1969).

Quanto aos fatores da seletividade dos principais herbicidas residuais utilizados na citricultura, estes estāo relacionados tanto ao posicionamento dos herbicidas no solo, bem como à tolerância fisiológica das plantas de citros aos herbicidas (JORDAN et alii, 1969).

Ainda, tem-se atribuido à rápida degradação dos herbicidas no solo, a provável auséncia de fitotoxicidade para as plantas de citros, mesmo em aplicaçōes repetidas (TUCKER \& PHILLIPS, 1969; PARRA et alii, 1973 e TUCKER, 1978). 
2.5. Importância dos fungos MVA nas plantas

As associaçōes entre raizes e determinados fungos do solo, denominadas micorrizas, ocorrem na maioria das espécies vegetais superiores.

O termo micorrizas foi inicialmente proposto pelo botánico alemão Albert Bernard Frank, em 1885, originando-se do grego, onde "mico" significa fungo e "riza", raizes (SIQUEIRA \& FRANCO, 1988).

Essas associaçōes envolvem fungos simbiotróficos, sem estágio patogênico, que vivem e, se alimentam em simbioses, tornando essas associaçōes mutualisticas, podendo ser agrupadas com base na anatomia das raizes colonizadas em ectomicorrizas, ectendomicorrizas e endomicorrizas.

Os agrupamentos micorrizicos se identificam por serem: a) as ectomicorrizas caracterizadas pelas penetraçōes intercelular do micélio fúngico, formaçāo da rede de Hartig, no interior do córtex, e do manto, que se desenvolve ao redor dos segmentos das raízes colonizadas. Além destas características anatômicas, são ainda evidentes as modificações morfológicas nas mesmas raízes. b) as ectendomicorrizas geralmente sāo ectomicorrizas com penetração intracelular, havendo diferenças anatômicas em funçāo da planta hospedeira, em sub-grupos das Pinaceales, e das Ericales do gênero Arbustos e Monotropa. c) as endomicorrizas caracterizadas pela penetraçāo inter e intracelular, ausência de manto e de modificaçōes morfológicas nas raízes. São de ocorrência muito generalizada e se subdividem em Ericóides, Orquidóides e VesicularArbusculares (LOPES et alif, 1983 e SIQUEIRA \& FRANCO, 1988).

Do ponto de vista ecológico e sob consideraçōes práticas, as ectomicorrizas e endomicorrizas MVA sāo as mais importantes. Apresentam as ectomicorrizas baixa diversidade de espécies para plantas hospedeiras, com cerca de 2.000 espécies, predominando nas Gimnospermas, e de ocorrência em poucas espécies de Angiospermas. Apresentam alta diversidade para os fungos simbiontes, sendo conhecidas em torno de 5.000 espécies (SIQUEIRA \& FRANCO, 1988).

Os mesmos autores apresentam ainda, uma lista parcial de famílias e gêneros de angiospermas e gimnospermas que formam ectomicorrizas. 
Dentre as endomicorrizas destacam-se as do tipo Vesículo-arbusculares (MVA) que sāo aquelas formadas por fungos da familia Endogonoceae (Subdivisāo Zigomicotina) e a maioria das espécies vegetais superiores (MOSSE, 1981). As MVA ocorrem em $97 \%$ das plantas vasculares, pelo menos 300.000 espécies, sendo conhecidas em torno de 140 espécies de fungos. No Brasil, os principais gêneros encontrados sāo Glomus, Acaulospora, Scutellospora, Glgaspora, Entrophospora e Sclerocystls (SIQUEIRA \& FRANCO, 1988).

As MVA sāo de distribuiçāo generalizada, no entanto, as famílias das Crucíferae, Chenopodiaceae, Cyperaceae, e famílias de plantas caracterizadas como plantas que formam ectomicorrizas, entre elas as Pinaceae, Betulaceae e Fagaceae nāo formam esta simbiose (GERDEMANN, 1975).

SIQUEIRA \& FRANCO (1988) comentam que ao contrário das ectomicorrizas, nas MVA nāo se verificam modificaçōes anatômicas resultantes da invasāo das raízes pelo fungo, nāo sendo assim reconhecidas sem ajuda de aparelho ocular. E que as raizes de algumas plantas como cebola, milho e outras representantes da família Liliaceae, tornam-se amareladas quando micorrizadas. Ainda, observaçōes microscópicas têm mostrado que os fungos penetram nas células corticais das raizes sem causar danos, o que os diferencia dos fungos patogénicos, fato também verificado nos outros tipos de micorrizas com penetração intracelular.

Citando que levantamentos realizados em várias regiōes do mundo mostram que as MVA sāo bem mais abundantes que as ectomicorrizas, apresentando-se nos trópicos, cerca de 10 vezes mais ocorréncia, estando presente na maioria das espécies vegetais. São encontrados em $\mathbf{9 7 \%}$ das Fanerogamas, incluindo quase todas as espécies de interesse agronômico, pastoril e várias florestais, além de serem importantes para a composição florística e a estabilidade dos ecossistemas naturais.

A fisiologia das micorrizas para esses autores, sāo de que o tipo e intensidade de micorrizas encontradas nas raízes, bem como o seu funcionamento, sāo determinados pelos genomas do fungo e da planta, modelados pelo ambiente, que $e$ representado pelo solo e clima. A penetração e o crescimento do fungo nas raízes, resultam em modificaçōes na fisiologia, bioquímica e nutriçāo da planta hospedeira, exercendo enorme efeito sobre seu comportamento. Estabelecida a simbiose, ambos 
organismos sāo beneficiados. As hifas externas do fungo funcionam como extensōes do sistema de absorçāo do hospedeiro, transportando nutrientes de zonas dentro e fora do alcance das raízes absorventes para as células corticais. Dentre os nutrientes, 0 fósforo é o mais importante do ponto de vista nutricional para o hospedeiro. 0 processo de absorçāo do fósforo pelas hifas é ativo, pois a concentraçāo iônica deste elemento no solo é usualmente menor que 1ppm, e as hífas contém 3.000 ppm. Após absorvido, o fósforo é convertido em grånulos de polifosfato nos vacúolos e transportado, pela corrente citoplasmática, até as vesículas onde pode ser armazenado temporariamente, ou ir diretamente para os arbúsculos, onde é hidrolizado pelas fosfatases, em fosfatos inorgânicos que é transferido à célula vegetal, passando pela interface fungo-planta denominada matriz. O fosfato inorgânico transferido para a planta é transportado até o xilema e translocado para outras partes, principalmente para as folhas, onde desempenham papel de grande importância no controle da colonizaçāo radicular em benefício da associaçāo. Simultaneamente e em sentido contrário, ocorre a transferência de carbohidratos oriundos da fotossintese, que atingem as raizes, via floema, na forma de sacarose. Nas raizes, a sacarose é hidrolizada pela invertase e os monómeros glicose e frutose, ou seus derivados, sāo transferidos para o fungo, via arbúsculos. Arbúsculos sāo estruturas semelhantes a haustórios, ou ainda hifas enoveladas, os chamados "pelotōes", ou "tortil" (LOPES et alfi,1983). Estas estruturas atuam diretamente nos processos de transferéncia de nutrientes absorvido do solo pelo fungo e de fotossintatos da planta entre os simbiontes (COX et alfi,1975). Os arbúsculos podem ser formados 2 a 3 dias após o estabelecimento da simbiose, permanecendo por um período aproximado de 1 a 3 semanas até serem degenerados (MOSSE, 1981).

As glicose e frutose sāo entāo metabolizadas para fornecerem energia ao sistema e sustentar o crescimento e a esporulaçāo do fungo.

Portanto, a transferéncia de fotossintatos da planta para o fungo, e de nutrientes minerais absorvidos pelas hifas no solo, para a planta, representam as bases do funcionamento e dos efeitos desta simbiose.

Deve-se considerar ainda a idade e a fase de desenvolvimento da planta. Em geral, a taxa de colonizaçāo micorrizica e o número de esporos no solo são maiores 
depois do período de máximo desenvolvimento das raízes, (HAYMAN, 1970), o que, provavelmente ocorre a partir do florescimento da planta, (SAIF \& KHAN, 1975).

Os efeitos benéficos da simbiose MVA podem resultar de um ou mais mecanismos destacando-se: a) aumento na absorção e melhor conservaçāo de nutrientes; b) aumento na nodulaçāo e fixaçāo do $\mathrm{N}_{2}$ atmosférico; c) alteração na relaçāo planta-patógeno; d) alteraçāo na relaçāo água-solo-planta; e) aumento na produçāo de fitohormónios; f) modificaçōes anatómicas e fisiológicas do hospedeiro; g) melhor adaptabilidade de planta às condiçōes adversas. Estes mecanismos geralmente, apresentam certa interdependência, o que dificulta sobremaneira sua caracterizaçāo e individualizaçāo (FERNANDES, 1987; ANTUNES, 1987; BALOTA, 1989 e FONTANEZZI, 1989).

Fatores de manejo do solo como a aplicação de fertilizantes e/ou corretivos ao solo provocam uma modificaçāo nas suas condiçōes físicas, químicas e biológicas e com isto os fungos MVA indígenas podem nāo se adaptar às novas condiçōes, resultando em reduçāo na colonizaçāo das raízes (MOSSE, 1981).

É sabido que os principais fertilizantes que afetam o desenvolvimento micorrizico sāo os nitrogenados e fosfotados (HAYMAM, 1970). Com a aplicaçāo de $45 \mathrm{Kg} / \mathrm{ha}$ de fósforo, KUCEY \& PAUL (1983) verificaram que a colonizaçāo das raízes de fava Vicia faba caiu de $47 \%$ para $15 \%$ e o número de esporo foi reduzido à $50 \%$.

Os fungos MVA respondem diferentemente quanto à adiçāo de fertilizantes fosfatado no solo (FERNANDES, 1987).

Também, o modo e a época de aplicação dos fertilizantes fosfatados, podem ter importância marcante sobre a simbiose MVA. Os efeitos da aplicaçāo de fertilizantes fosfatados sobre a porcentagem de colonizaçāo têm sido maior no primeiro ano e estes efeitos declinam no segundo ano, por causa da seletividade de desenvolvimento da simbiose (SPARLING \& TINKER, 1978). Entretanto, a aplicação parcelada destes fertilizantes fosfatados, diminui sua ação detrimental sobre a simbiose (CHILVERS \& DAFT, 1981).

Em solos com nivel médio de fósforo SYLVIA \& SCHENCK (1983), verificaram que a aplicaçāo de superfosfato aumentou a eficiência de esporulaçāo de Gigaspora margarita e Gigaspora heterogama, e diminuiu, significativamente, a eficiência de 
esporulaçāo de Glomus etunlcatum e Glomus macrocarpum. Este aumento na eficiência de esporulação após a aplicaçāo de superfosfato foi considerada pelos autores como sendo devido a uma melhora real na eficiência de produçāo de esporos ou ao aumento no comprimento das raizes, sobre as quais os esporos podem desenvolver-se.

Outro aspecto que deve-se considerar, é o efeito da monocultura sobre o desenvolvimento da simbiose MVA, por ser muito variável de espécie para espécie. Contudo, alguns tipos de monocultura podem diminuir a populaçāo fúngica (SCHENCK \& KINLOCK, 1980).

Por outro lado, tem-se observado que após 16 anos de monocultura com trigo, as parcelas apresentaram 35 vezes mais esporos que as com batata, sendo que este fato pode estar relacionado com a maior ou menor susceptibilidade do hospedeiro em formar simbiose MVA (KRUCKELMANN, 1975).

Também, algumas espécies de plantas citadas como não micorrizicas, como é o caso de Chenopodium album L., podem até apresentar colonização quando em presença de plantas de citros micorrizadas (HIRREL et alii, 1978).

Em citros os beneficios das associaçסes micorrizicas tornam-se evidentes principalmente em viveiros ou em situaçōes de replantio onde os fungos MVA de ocorrência natural sāo destruidos pela fumigaçāo do solo (KLEINSCHMIDT \& GERDEMANN, 1972 e MENGE et alii, 1975).

Nos Estados Unidos da América do Norte a prática de fumigaçāo do solo é muito difundida para eliminação de patógenos (MARTIN, 1948; MARTIN et alii, 1953 e 1963 e MENGE et alii, 1977). No entanto, tem-se verificado o aparecimento de plantas cítricas com crescimento limitado, vigor reduzido com sintomas de necrose e bronzeamento das folhas em sementeiras, viveiros, pomares e em casa de vegetaçāo quando cultivadas em solo previamente fumigado (MARTIN et alii, 1963; KLEINSCHMIDT \& GERDEMANN, 1972; SCHENCK \& TUCKER, 1974; TIMMER \& LEYDEN, 1976 e 1978). Tais sintomas, caracterizando deficiência de nutrientes e paralização do crescimento dessas plantas têm sido atribuido à morte dos fungos MVA por ocasiāo da fumigaçāo (GERDEMANN, 1968; HATTINGH \& GERDEMANN, 1975; 
MENGE \& JOHNSON, 1978 e MENGE et alil, 1977), e, nāo a uma Inadequada adubaçāo fosfatada do solo (TIMMER \& LEYDEN, 1978).

Assim, esses efeitos prejudiciais podem ser eliminados pela inoculaçāo dessas plantas com determinados fungos micorrizicos (KLEINSCHMIDT \& GERDEMANN, 1972 e SCHENCK \& TUCKER, 1974). A introduçāo desses fungos MVA em solos fumigados, segundo MENGE et alii (1975) passa a ser um fator indispensável para a obtenção de um desenvolvimento ótimo das plantas cítricas, tendo-se obtido aumentos da ordem de 20 a $2600 \%$ no crescimento dessas plantas Inoculadas (MENGE et alii, 1977).

Entretanto, além dos fungos MVA estimularem o crescimento do citros, a micorriza pode reduzir significativamente aplicaçōes de adubos fosfatados ao substrato (TIMMER \& LEYDEN, 1979; GRAHAM \& TIMMER, 1984 e CARDOSO et alii, 1986).

Assim, plantas cítricas micorrizadas podem atingir concentraçōes ótimas de fósforo com menores quantidades de fosfato adicionado (MENGE, 1983).

Ainda, se constatou que plantas cítricas nāo micorrizadas geralmente apresentam concentraçōes mais baixas de fósforo nos tecidos (KRIKUN \& LEVY, 1980 e ZAMBOLIM \& PINTO, 1985), com ocorrência de severa e freqũente deficiência de fósforo na ausência de fungos MVA (KLEINSCHMIDT \& GERDEMANN, 1972).

As espécies de fungos MVA diferem quanto à efetividade na promoçāo do desenvolvimento das plantas cítricas (EDRISS et alii, 1984 e FONTANEZZl et alii, 1987). Contudo, como ocorre para outras espécies vegetais, a magnitude das respostas à inoculaçāo com fungos MVA em citros, é funçāo dos seguintes fatores: a) disponibilidade de fósforo no solo (MENGE et alii, 1978; HAYMAN, 1982 e ANTUNES \& CARDOSO, 1987). b) Taxa de colonizaçāo micorrizicas nas raízes (McGRAW \& SCHENCK, 1981). c) Expansāo do micélio externo às raízes (GRAHAM et alii, 1982). d) e das espécies de citros e de fungos associados (MENGE et alii, 1977 e NEMEC, 1978; DANIELS \& MENGE, 1981; CALDEIRA et alii, 1983 e EDRISS et alii, 1984).

Estudos realizados com as espécies de fungos MVA Glomus clarum, Acaulospora morrowae isoladamente e a mistura entre as espécies de Glomus macrocarpum, Gigaspora margarita, Scutellospora heterogama, Glomus clarum e Acaulospora morrowae mostraram-se mais efetivos na promoçāo do desenvolvimento de limoeiro "Cravo" quando comparados com tratamentos inoculados com G. 
macrocarpum, G. margarita e S. heterogama, isoladamente (FONTANEZZl ot alii, 1987). Já, Gigaspora gilmorei e Glomus leptotichum têm se mostrado eficientes para o limāo "cravo", Citrus volkameriana e laranja "Caipira" (CARDOSO et alii, 1986).

Define-se dependência micorrízica, segundo GERDEMANN (1975), como o grau no qual a planta é dependente da condiçāo micorrízica para produzir o máximo crescimento ou produçáo a um dado nivel de fertilidade do solo. Assim, tem-se verificado que algumas espécies de citros sāo muito dependentes dos fungos MVA para a melhoria da eficiência de seus sistemas radiculares, sendo observado que esta dependéncia é mais pronunciada em condiçōes de menor disponibilidade de fósforo no substrato (GRAHAM, 1986).

A inoculaçāo de citros com fungos MVA, em casa-de-vegetaçāo, pode ser feita a partir de esporos dos fungos, micélio e raízes de plantas hospedeiras colonizadas ou solo contendo todos esses componentes colocados próximos às sementes ou em contato direto com as raizes de citros (KLEINSCHMIDT \& GERDEMANN, 1972; HATTINGH \& GERDEMANN, 1975 e MENGE ot alii, 1977). Ainda, inoculantes constituidos por mistura de esporos, micélio e raizes infectadas possui, geralménte, maior potencial de inoculaçāo do que esporos purificados ou material de raízes. Entretanto, esse tipo de inoculante tem dificultado a quantificação e a precisão dos resultados (MENGE \& TIMMER, 1982).

SIQUEIRA \& FRANCO (1988) citam que se considerar as condiçōes edafoclimáticas, as aptidōes agroflorestal e pastoril e a escassez de recursos financeiros e materiais destinados à agricultura, existe no Brasil um enorme potencial para o uso dos fungos micorrizicos. E que a aplicaçāo biotecnológica dos inoculantes ectomicorrizicos em larga escala, no setor de reflorestamento, seria facilitada se a tecnologia disponivel no exterior fosse adaptada às condiçōes climáticas e mercadológicas existentes no pais.

Por outro lado, o uso dos fungos MVA se expandiria se espécies ou isolados com elevada efetividade/eficiência simbiótica e competitividade fossem selecionados e se tecnologias viáveis economicamente para produção, armazenamento e aplicaçāo de inoculante, fossem desenvolvidas. 
Assim, a utilizaçāo desses fungos despertará maiores interesses quando a oferta ou o custo dos fertilizantes, especialmente dos fosfatados, tornarem-se limitantes.

\subsection{Fatores que influenciam as micorrizas}

As micorrizas são influenciadas por fatores inerentes à planta, ao fungo e edafoclimáticos, que atuando sobre os propágulos ou sobre as diferentes fases da simbiose, afetam a sua formaçāo e o seu funcionamento, bem como as relaçōes ecológicas ligadas a essas associaçōes.

Neste item sāo discutidos os fatores edafo-climáticos, que atuam tanto na formaçāo como no funcionamento e ocorrência da simbiose que sāo: disponibilidade de nutrientes, pH do solo, características físicas do solo, luz e temperatura, matéria orgånica, microbiota e fauna, e, flutuaçāo sazonal.

\subsubsection{Disponibilidade de nutrientes}

A micorrizaçāo é geralmente inibida em condiçōes de elevada fertilidade, sendo verificado por diversos pesquisadores, que nestas condiçőes a ocorréncia e intensidade da simbiose MVA são significativamente menores (GIANINAZZI-PEARSON et alii, 1980; JENSEN \& JAKOBSEN, 1980, MOSSE et alif, 1981 e SIQUEIRA \& FRANCO, 1988).

Dentre os nutrientes essenciais à planta, o fósforo e o nitrogênio são os que exercem efeitos mais acentuados na simbiose, sendo esses mais relatados nas MVA do que nas ectomicorrizas.

Inúmeros trabalhos têm mostrado que altos niveis de fósforo no solo diminuem a colonizaçāo micorrizica, bem como a respota do hospedeiro à simbiose (COOPER, 1975; SMITH, 1978 e KUCEY \& PAUL, 1983).

Dos efeitos do fósforo nas MVA, sabe-se que ele atua no estabelecimento e funcionamento da simbiose e na distribuiçāo e composiçāo das espécies. Tanto o fósforo quanto o nitrogênio nāo exercem efeitos fungistáticos ou fungicidas sobre os propágulos do fungo na rizosfera, pelo menos em concentraçōes próximas do ótimo requerido pela planta hospedeira (SIQUEIRA \& FRANCO, 1988). 
Para SANDERS (1975) os efeitos do fósforo sobre a colonização das raízes são indiretos via planta. Segundo SIQUEIRA \& FRANCO (1988), aumentando-se a disponibilidade deste elemento no solo, aumenta sua absorçáo pela planta e sua concentraçāo na parte aérea, onde ele atua nos processos fisiológicos e/ou metabólicos relacionados à fotossintese, crescimento, partição e distribuição de fotossintatos na planta, que atuam no estabelecimento e funcionamento da associação, agindo como um mecanismo de autoregulação da simbiose. Esse mecanismo, citam os autores, é diferente nos diferentes tipos de micorrizas, e até diferentes sistemas fungo-planta do mesmo tipo. Aplicaçōes de pequenas quantidades de fertilizantes podem favorecer o desenvolvimento de micorrizas, em solos com alto grau de deficiéncia, mas quantidades mais elevadas inibem a colonizaçāo, estando esses efeitos relacionados com o estado nutricional da planta. Plantas de soja com mais de $0,13 \%$ de fósforo e 2,2\% de nitrogénio na parte aérea, apresentam redução na colonização, e, para o milho verificou-se uma relação linear inversa entre o teor de fósforo na planta e a colonização das raízes.

O nível crítico de fósforo para o desenvolvimento da simbiose MVA é determinado pelo conteúdo de fósforo no solo e sua taxa de difusāo, bem como, da espécie vegetal que desenvolve sobre ele (COOPER, 1975).

Algumas espécies de fungos, no entanto, parecem adaptar-se bem a diferentes niveis de fósforo no solo. Assim por exemplo, Glomus intraradices e Glomus etunicatum ocorreram em solos com teores de fósforo disponivel variando entre 2,8 a 448 ppm (SCHENCK \& SMTH, 1981).

Efeitos benéficos foram observados em mudas de cafeeiros inoculados com Gigaspora margarita por COLOZZI-FILHO \& SIQUEIRA (1986), as quais apresentaram máximo desenvolvimento vegetativo e ín dice de colonizaçāo, quando desenvolvidos em substrato com nivel de fósforo disponivel de 24 ppm. Ainda, verificou-se que este efeito benéfico, foi ligeiramente diminuido em maiores niveis de fósforo disponivel, atingindo efeito negativo a partir de $\mathbf{8 0}$ ppm. Nas condiçōes daquele experimento os autores concluíram que, o máximo efeito benéfico para a simbiose e crescimento vegetativo, obtém-se com níveis de fósforo disponivel no substrato em torno de $50-60$ ppm. 
Por outro lado, o nitrogénio em alguns casos tem sido considerado até mais depressivo que o fósforo (HAYMAN, 1970). Com a forma $\mathrm{N}-\mathrm{NH}_{4}{ }^{+}$parecendo ser mais inibitória para a simbiose MVA do que a forma N-NO; (BROWN et alli, 1981). Porém, a influência da interaçāo nitrogénio x fósforo na simbiose MVA ainda nāo está bem esclarecida (FERNANDES, 1987). Contudo, sob condiçōes controladas, HAYS et alii (1982), observaram que aparentemente, existe pouco efeito do fósforo tanto do tecido foliar como do solo sobre a colonização micorrizica, quando esta já está limitada pela disponibilidade de nitrogénio.

A elevação na disponibilidade de nutrientes no solo, especialmente de fósforo, além de reduzir a colonização das raízes, pode diminuir a esporulação e a diversidade de espécies fúngicas (SIQUEIRA \& FRANCO, 1988). Citando ainda, que sobre a ocorrência de certas espécies de fungos MVA, com relação à infiuéncia do fósforo disponivel no solo, têm-se observado em solos do Estado de Minas Gerais que enquanto Acaulospora scrobiculata e Glomus etunicatum sāo favorecidas por altos niveis de fósforo no solo, as demais são reduzidas.

Existem poucas informaçōes acerca da influéncia de outros nutrientes sobre a simbiose MVA (FERNADES, 1987). Entretanto, ao contrário do que ocorre com os macronutrientes nitrogénio e fósforo, os micronutrientes $(\mathrm{Zn}, \mathrm{Cu}, \mathrm{Mn}$ e $\mathrm{Fe}$ ) e outros elementos, como o Al e metais pesados atuam diretamente sobre os propágulos, que apresentam elevada sensibilidade à toxicidade desses ions (SIQUEIRA \& FRANCO, 1988).

A adiçāo de sulfato de zinco aumentou a colonizaçāo micorrizica da soja por Glomus mosseae, diminuindo nas doses superiores a $45 \mathrm{mg}$ de zinco por quilo de solo (MCILVEEN \& COLE, 1978). Em solos que apresentaram toxicidade ao alumínio os esporos de MVA foram pouco frequentes e as árvores de macieira apresentaram baixa colonização micorrízica (TRAPPE et alii, 1973).

Esses efeitos diferenciados promovem modificaçōes na capacidade do solo em formar micorrizas e, se esta for muito reduzida, pode favorecer o aparecimento de distúrbios nutricionais e/ou doenças do sistema radicular, aumentando o requerimento de nutrientes pelas culturas, reduzindo sua toleråncia ao estresse hídrico e, conseqũentemente, sua sobrevivencia e produtividade (SIQUEIRA \& FRANCO, 1988). 


\subsection{2. pH do solo}

$\mathrm{O} \mathrm{pH}$ do solo influencia qualitativa e quantitativamente os fungos MVA, sendo alguns mais eficientes em pH baixo, outros em pH alto, enquanto outros são moderadamente eficientes em uma larga faixa de pH (POWELL, 1977).

Num estudo comparativo, em alguns solos da Austrália, sobre a distribuição e abundáncia do fungo MVA, ABBOT \& ROBSON (1977), verificaram que em solos com pH acima de 5,3 ocorreram somente esporos de Glomus e, em solos com pH abaixo de 4,6, apenas Acaulospora e naqueles com pH entre 4,6 a 5,3 ambos os gêneros. Contudo, esporos de Acaulospora, em outras localidades, ocorreram em pH menores que 5,4 , sugerindo que outras propriedades do solo relacionada com o pH influência sua ocorrência.

$O$ fato de fungos MVA serem observados em solos com pH que variam desde 2,7 (DAFT et alii, 1975), a 9,2 (BOWEN, 1980), é uma evidéncia de sua alta capacidade de adaptaçāo fisiológica. Tem-se verificado que populaçōes de Gigaspora e Acaulospora apresentam maiores índices de germinação de esporos, colonizaçāo radicular e ocorrência natural em pH mais baixo, enquanto populaçōes de Glomus apresentam niveis ótimos em pH mais alto, próximos ou superiores a 7,0 (SIQUEIRA et alii, 1986; LAMBAIS \& CARDOSO, 1988). Entretanto, a colonização de raízes mostrouse mais sensivel à variação do pH que à germinaçāo dos esporos (LAMBAIS \& CARDOSO, 1988), sendo que em relação a colonização (HAYMAN \& TAVARES, 1985), observaram diferentes espécies apresentando seus ótimos de desenvolvimento em relação ao pH.

Por estas observaçōes, sugere-se que o pH isoladamente nāo se constitui no único fator de controle da colonizaçāo das raízes em solos ácidos e, que outros fatores como Al, Mn e outros metais podem atuar como agentes fungistáticos (SIQUEIRA et alii, 1984).

Outros trabalhos, no entanto, nāo encontraram influência do pH sobre o desenvolvimento micorrízico em condiçōes naturais (READ et alii, 1976 e SPARLING \& TINKER, 1978). Tal fato, vem reforçar a hipótese de que o desenvolvimento micorrízico 
nāo é afetado tāo somente pelo pH do solo, mas também, por modificaçōes nas concentraçōes dos diversos íons do solo.

O mecanismo de açāo do pH sobre os fungos MVA e sua simbiose é pouco conhecido, mas acredita-se que esses efeitos possam resultar da açāo direta de lons $\mathrm{H}^{+}$, ou de mudanças nas propriedades químicas do solo, atuando sobre o fungo, a planta ou a simbiose (SIQUEIRA et alii, 1986).

Em condiçōes de campo é muito difícil de se avaliar o efeito do pH sobre o desenvolvimento da simbiose pois, várias propriedades do solo estāo correlacionadas com este parâmetro (FERNANDES, 1987).

Também, tem se verificado que algumas espécies de fungos apresentam distribuiçāo generalizada, como as espécies de Glomus Intraradices e Glomus etunicatum encontradas em solos ácidos e básicos de todo o estado da Fiórida - EUA (SCHENCK \& SMITH, 1981).

Em geral, a calagem dos solos minerais ácidos elimina os fatores fungistáticos e favorece o estabelecimento das MVA, especialmente daquelas formadas por espécies do género Glomus, que, com poucas exceçōes preferem solos com pH próximo do neutro a alcalino, ao contrário do que é observado para a maioria das espécies dos géneros Acaulospora, Gigaspora, Scutellospora e Entrophospora, que preferem pH na faixa ácida (SIQUEIRA \& FRANCO, 1988). Ainda, para os mesmos autores a calagem dos solos minerais ácidos nāo cultivados pode, pelo menos temporariamente, reduzir a formaçāo de micorrizas, pois a elevaçāo do pH pode ter efeitos adversos sobre a infectividade dos fungos nativos, naturalmente adaptadas às condiçōes ácidas.

Variaçōes no pH interferem no índice de ocorréncia das espécies e densidade de esporos na rizosfera do cafeeiro (FERNANDES, 1987). A elevaçāo do pH para próximo da neutralidade, nos canteiros de formaçāo de mudas de espécies florestais como o Pinus, constitui uma limitaçāo para o bom desenvolvimento do Pisolithus tinctorius e Cenococcum graniforme nas raizes. Também, existem fungos ectomicorrízicos como espécies dos gêneros Ahizopogon, Boletus e Tuber, que nāo toleram os solos ácidos (SIQUEIRA \& FRANCO, 1988).

Entretanto, citam que os efeitos do pH sobre as condiçóes químicas e biológicas do solo, como a solubilidade de certos elementos com açāo fungistática (Al, Mn) em 
condições ácidas, e o favorecimento de bactérias e actinomicetos antagonistas em pH neutro, que influenciam significativamente na formaçāo das micorrizas, precisam ser melhor avaliados nos solos tropicais.

\subsubsection{Caracteristicas fisicas do solo}

O nivel de umidade do solo, aeraçāo, inundaçāo e a textura influenciam as micorrizas. Solos com elevado teor de umidade ou sujeitos à inundaçāo, portanto com aeraçāo deficiente, sāo geralmente desprovidos de micorrizas, porque os fungos micorrizicos sāo aeróbicos obrigatórios (SIQUEIRA \& FRANCO, 1988).

Em plantas de Ipomoea carnea quando desenvolvidas temporariamente em solos alagados e barrentos, nāo se encontrou esporos, contudo, em plantas desenvolvidas em solos secos observou-se alta densidade de esporos (KHAN, 1971). Resultados semelhantes, RABATIN (1979) encontrou quando estudava colonizaçāo micorrizica em gramineas. Plantas estressadas hidricamente também apresentaram maior colonizaçāo em relação as que receberam adequado suprimento de água (NELSEN \& SAFIR, 1982).

Concordando, BOLGIANO et alii (1983), constataram um aumento na colonizaçāo com a reduçāo na umidade, para os mesmos niveis de fósforo. Contudo, plantas crescidas em ambiente com alta umidade no solo, podem apresentar-se micorrizadas, porém, com baixo índice de colonizaçāo (READ et alii, 1976).

Em regiōes com altos niveis de precipitaçāo, MOSSE \& BOWEN (1968) verificaram que a ocorrência de esporos pode diminuir, enquanto que a deficiência hídrica parece nāo influenciar acentuadamente a simbiose, sendo encontrado por SAITO et alii (1983), propágulos desses fungos em condiçōes extremamente secas. No entanto, o desenvolvimento de micorrizas é favorecido por condiçōes próximas à capacidade de campo (SIQUEIRA \& FRANCO, 1988).

A germinaçāo de esporos de Glomus epigaeum, foram doze vezes maior em solos com $50 \%$ de umidade do que a 10\% (DANIELS \& TRAPPE, 1980), tendo-se 0 número de esporos correlacionado negativamente com a umidade do solo e positivamente com o crescimento da planta (ANDERSON et alii, 1983). 
A alternância entre ciclos de umidade e secagem parece favorecer a esporulação dos fungos MVA, e os níveis elevados de umidade no solo favorecem o desenvolvimento de hiperparasitas de esporos micorrizicos, reduzindo a viabilidade dos mesmos como propágulos (SIQUEIRA \& FRANCO, 1988).

Outras condiçóes do solo, como a textura, determinam a distribuição espacial do número de esporos. Em solos argilosos, ALLEN \& ALLEN (1980), encontraram menor número de esporos, concordando com a sugestão de GRIFFIN (1972), de que em solos de textura fina, com pequenos poros, existe a possibilidade da produçāo de menor número de esporos. Assim, a variaçāo espacial pode ocorrer devido às características físico-químicas do solo, aliadas às características de algumas espécies de fungos MVA esporularem em grupos ou agregados ou mesmo dentro de raízes, o que possibilita a ocorrência de maior número de esporos em microsítios com menor textura e/ou próximo às raízes (WALKER et alii, 1982 e ANDERSON et alii, 1983).

A partir destas consideraçóes, para se avaliar populaçāo micorrizica associada a plantas perenes, é de extrema importância estudos para determinaçāo da área amostrada com melhor representatividade, uma vez que a populaçāo de esporos, como visto pode ser influenciada pelo estádio de desenvolvimento da planta hospedeira e pela distribuiçāo do seu sistema radicular.

\subsubsection{Luz e Temperatura}

A temperatura do solo é outro fator físico de grande importância para as micorrizas. Ela interfere na sobrevivência dos propágulos e no estabelecimento e funcionamento da simbiose, porém, tanto os fungos ectomicorrízicos, como os MVA, exibem elevada capacidade de ecoadaptação à temperatura (SIQUEIRA \& FRANCO, 1988).

Conhecimentos básicos dos efeitos da temperatura sobre a colonizaçāo da raiz, bem como a resposta da planta em crescimento e a esporulação dos fungos MVA, são de grande importância na perspectiva da aplicaçāo prática destes fungos na agricultura (BALOTA, 1989). 
Em condiçāo de casa-de-vegetaçāo, a luz e a temperatura podem afetar a colonizaçāo (HETRICK, 1985). Respostas diferentes sāo observadas para diferentes associaçōes de fungo/hospedeiro, em relaçāo às mudanças de luz e temperatura (FURLAN \& FORTIN, 1973 e HAYMAN, 1974). O efeito da temperatura sobre a comunidade fúngica MVA, pode ser considerado como efeito direto sobre o fungo micorrizico e indireto sobre a planta (KOSKE, 1987).

A intensidade da luz e dias longos, aumenta o nivel de colonizaçāo (JOHNSON et alii, 1982), onde se deduz que o menor desenvolvimento da colonizaçāo em condiçōes de baixa luminosidade, ocorre por ser a luz um fator limitante à fotossíntese (HAYMAN, 1974).

Esta hipótese por sua vez é reforçada por BETHLENFALVAY \& PACOVSKY (1982), em estudo realizado sob condiçōes controladas em soja, no qual observaram uma relaçāo positiva entre o aumento da luminosidade e da colonizaçāo micorrízica.

Foi também encontrado evidências sobre a influência da temperatura no estabelecimento e disseminaçāo da colonizaçāo, bem como na reprodução de esporos, sendo nas condiçōes de altas temperaturas os indices de colonizaçāo e de esporulaçāo maiores (FURLAN \& FORTIN, 1973 e HAYMAN, 1974). Algumas espécies possuem o seu máximo de colonizaçāo e de esporulaçāo em temperaturas diferentes, enquanto outras possuem numa mesma temperatura (SCHENCK \& SMITH, 1982).

\subsubsection{Matéria orgånica}

É de conhecimento geral que a matéria orgånica influencia a estrutura do solo, $\mathrm{pH}$, capacidade de retenção de água e nutrientes, os quais podem influenciar direta ou indiretamente a simbiose, MVA (GIANINZZI - PEARSON \& DIEM, 1982). A presença da simbiose MVA pode estar relacionada com o teor de matéria orgânica do solo (St. JOHN \& MACHADO, 1978). Tanto assim que o número máximo de esporos ocorreu em solos com 1-2\% de matéria orgânica, enquanto que em solos com menos de $0,5 \%$ de matéria orgånica apresentam poucos esporos (SHEIKH et alii, 1975).

Sob condiçōes de campo, abundante colonizaçāo com arbúsculos e hifas foi observado em algodoeiro adubado com esterco (JOHNSTON, 1949), enquanto que a 
adiçāo de palhas em solos cultivados aumentou o número de esporos (KRUCKELMANN, 1975).

Camadas húmicas de solos florestais podem apresentar pedaços de raízes micorrizadas, (St. JOHN \& COLEMAN, 1983), assim comó sementes mortas, (HIRREL ot alii, 1978) e sementes viáveis no solo, (TABER, 1982), podem conter pedaços de hifas e esporos.

Há relatos de que as hifas de fungos MVA podem exercer atividade saprofítica (WARNER, 1984). Com quanto, os estudos realizados até o momento dāo conta que o fungo é um simbionte obrigatório, multiplicando-se apenas na presença do hospedeiro (SIQUEIRA et alii, 1985).

\subsubsection{Microbiota e Fauna}

Certos componentes da microbiota do solo, como fungos, bactérias e actinomicetos, segundo SIQUEIRA \& FRANCO (1988), podem atuar como parasitas, antagonistas e comensalistas, em relaçāo aos fungos micorrizicos, citando que no primeiro caso, tem-se os hiperparasitas, como Rhizidiomycopsis, Phlyctochytrium, Anquillospora e Humicola, que parasitam esporos, tubo, germinativo e micélio, inviabilizando os propágulos dos fungos MVA no solo. Também, o fungo Stachyboings chartarum e actinomicetos do solo inibem a germinaçāo de esporos, sendo que os últimos produzem substâncias voláteis, com elevado poder fungistático. Ainda, determinadas bactérias favorecem a germinaçāo de esporos, e aquelas produtoras de enzimas pectolíticas favorecem o estabelecimento do fungo MVA nas raízes. Além dessas, relaçōes de potenciaçāo entre fungos MVA e rizóbio, bactérias solubilizadoras de fosfato ou Azotobacter parecem ocorrer. Por último, os fungos ectomicorrizicos parecem ter também relaçāo de potenciaçāo com as bactérias fixadoras de nitrogénio em vida livre, que se multiplicam abundantemente na micorrizosfera e podem, ocorrer até mesmo nos bandiocarpos.

Os fungos formadores de simbiose MVA, sāo considerados como componentes da microflora do solo, por se desenvolverem em condiçōes naturais na maioria das plantas (KHAN, 1971). Embora, se dê interaçōes antagonísticas com certos organismos 
do solo, é frequente a predaçāo da hifa por nematóides e microartropodes (St. JOHN \& COLEMANN, 1983). Também, patógenos de raízes e nematóides podem reduzir a colonizaçāo micorrízica, provavelmente devido a competição entre os dois organismos por espaço ativo e nutrientes (LOPES et alii, 1983).

A desinfecçāo do solo favorece o desenvolvimento dos fungos MVA, principalmente, por nāo haver a competiçāo destes com os fungos nativos do solo. Tanto que, em solos não desinfectado a esporulaçāo de Glomus macrocarpum e Gigaspora gigante é reduzida significativamente (ROSS, 1980).

A fauna do solo tem participação ativa sobre os fungos micorrizicos, atuando na dispersāo de propágulos e alimentando-se de hifas e corpos de frutificaçāo, através da micofagia (SIQUEIRA \& FRANCO, 1988). Nematóides micbfagos, como os do gênero Aphelencoides sp, e Colembolas podem alimentar-se do micélio externo destes fungos (MOSSE et alii, 1981). Assim, os roedores, nematóides micófagos, colémbolas e outros animais que atuam no solo sāo importantes componentes dos sistemas micorrizicos, especialmente nos ecossistemas naturais (SIQUEIRA \& FRANCO, 1988).

\subsubsection{Flutuação sazonal}

Existe muita dificuldade em se fazer comparaçōes dos diferentes trabalhos encontrados na literatura de estudo de sazonalidade para os fungos MVA, devido a diversidade de ambiente, como clima, solo, hospedeiro e espécies de fungos MVA encontrados. Entretanto, salienta-se a importáncia e a necessidade de estudos da influência da sazonalidade na variabilidade de propágulos e na produção de esporos (GOULD \& LIBERTA, 1981).

Inúmeras observaçōes de flutuaçōes sazonais de fungos MVA, têm sido feitas em vegetação nativa, (BONONI \& TRUFEM, 1983), em culturas anuais de interesse económico, (HAYMAN, 1970; SUTTON \& BARRON, 1972; BLACK \& TINKER, 1979; HETRICK \& BLOOM, 1983; TRUFEM \& BONONI, 1985 e BONONI et alii, 1988), em culturas perenes, (ROLDAN - FAJARDO et alii, 1982 e NAPPI \& JODICE, 1984), em plantas de dunas, (NICOLSON \& JOHNSTON, 1979; GIOVANNETII, 1985; SYLVIA, 1986 
e GEMMA \& KOSKE, 1988, em partagens com gramíneas, (SPARLING \& TINKER, 1975 e RABATIN, 1979), e em samambaias (IQBAL et alfi, 1981).

Trabalhos realizados em áreas de praderias e de trigo, em condiçóes de campo em clima temperado, HETRICK \& BLOOM (1983), detectaram grande influência da estaçāo climática na abundância de esporos de fungos MVA, com maior número de esporos durante o verāo. O mesmo foi observado em culturas de trigo, tomate, milho, morango, (SUTTON \& BARRON, 1972), e em plantas de dunas o aumento no número de esporos ocorreu de abril/maio a agosto, no verāo (SYLVIA, 1986), e o morangueiro apresentou alto número de esporos, permanecendo constante até o verão seguinte (SUTTON \& BARRON, 1972).

Em condiçōes de clima tropical, estudos realizados com plantas nativas do cerrado e em oito culturas de interesse económico em áreas de cerrado, mostraram que ocorreu maior número de esporos em época mais quente e úmida (primavera/verão), evidenciando qualitativa e quantitavamente a influência da sazonabilidade (BONONI \& TRUFEM, 1983 e TRUFEM \& BONONI, 1985). Contudo, 0, hospedeiro apresenta grande influência da sazonalbilidade no padrāo de esporulação, sendo observado diferenciaçāo de esporulaçāo para diferentes hospedeiros, indicando que as diferentes espécies de fungos com capacidades próprias de esporulação, são influenciados diferentemente por fatores tanto dos hospedeiros como dos, ambientes (SUTTON \& BARRON, 1972; BONONI \& TRUFEM, 1983 e SYLVIA, 1986).

Tem-se encontrado em inúmeros casos, um maior númeró, de esporos após o crescimento radicular, maturaçāo ou senescéncia do hospedeiro, podendo estar correlacionada a produção de esporos com o estádio de desenvolvimento do hospedeiro (HAYMAN, 1970; SUTTON \& BARRON, 1972; NICOLSON \& JOHNSTON, 1979; IQBAL et alii, 1981; GIOVANNETTI, 1985; SYLVIA, 1986; KOSKE, 1987; e BONONI et alii, 1988).

No entanto, existe grande dificuldade em distinguir o efeito da sazonalidade de outros efeitos, como estádio do desenvolvimento dạ planta na formação da associação micorrizica e, principalmente, na produçāo de esporos, (MOSSE, 1973 e IQBAL et alii, . 1981). A proporção de raizes micorrizadas e nāo micorrizadas em plantas anuais se mantém constante durante o florescimento e a formaçāo do fruto, quando fotossintatos 
sāo desviados para processos consumidores de energia, (ROLDAN - FAJARDO et alli, 1982)

Para plantas perenes, tem sido sugerido comportamentos distintos dos verificados em plantas anuais com os fungos MVA, (GEMMA \& KOSKE, 1988), sendo nas condiçōes de clima temperado o crescimento radicular mais ou menos contínuo, observando-se que poucos esporos são produzidos, apesar do alto nivel de colonizaçāo radicial, (BAYLIS, 1969). Isso indica que talvez nestas condiçōes nāo exista um estímulo para a produção de esporos, uma vez que o crescimento radicial não é intermitente, concordando com SPARLING \& TINKER (1975).

Ainda, trabalhos conduzidos pelos mesmos autores com gramineas em pastagens apresentaram baixa esporulação durante 0 ano todo, mesmo com nível de colonizaçāo radicial alto, sendo maior no verāo e em torno de $40 \%$ menor, no outono, inverno e primavera.

Em solos com deficiência de fósforo, a colonização de Glomus tuneis em gramineas, apresentou-se maior na primavera em áreas de baixa umidade, e no fim do verão ou estação de crescimento, nas áreas de alta umidade (RABATIN, 1979). Este fator, umidade, e sua influência na colonizaçāo foi estudado por diversos pesquisadores, dentre eles BOLGIANO et alii (1983), verificaram aumento da colonização com a redução da umidade, nas mesmas condiçōes de teores de fósforo.

$\mathrm{Na}$ cultura da macieira foi observado que o número de esporos decresceu e 0 indice de infecçāo aumentou do verāo para o outono, (NAPPI \& JODICE, 1984), e em árvores de amêndoas, ROLDAN - FAJARDO et alii (1982), constataram que a colonização aumentou durante o inverno e primavera até o verāo, quando começou a decrescer. Por outro lado, o número de esporos apresentou aumento crescente na primavera com pico no outono e decréscimo significativo no inverno. Contrário a estas observaçōes, GIOVANNETTI (1985), encontrou em plantas de dunas porcentagem constante de colonizaçāo micorrizica durante o outono, com pequeno aumento de janeiro a junho, porém, decrescendo durante o verāo.

Estudos realizados em condiçōes de clima tropical, SAIF (1986), constatou que o número de esporos em população de fungo MVA associado a espécies forrageiras, aumentou de abril a junho (outono), mantendo-se constante até novembro (meados da 
primavera), com maior colonizaçāo no ínicio da estaçāo chuvosa e menor na estaçāo seca.

Devido a diversidade de ambiente, fatores bióticos e abióticos, importância agronómica dos fungos MVA, fica claro a necessidade de estudos que aumente o conhecimento do comportamento destes fungos e suas inter-relaçōes no processo produtivo agrosilvipastoril.

\subsection{Efeito dos herbicidas sobre os fungos MVA.}

A capacidade das micorrizas em aumentar o crescimento e a sobrevivência das plantas com significativos ganhos na produçāo, tem despertado 0 interesse de pesquisadores, de áreas afins, em estudar a influência dos defensivos agrícolas sobre esta relação simbiótica.

Dentre os defensivos agrícolas, destacam-se os herbicidas aplicados tanto no solo (pré-emergentes), ou sobre as plantas (pós-emergentes), que para GREAVES \& MALKOMES (1980) os efeitos dos mesmos sobre a infecçāo micorrízica de plantas cultivadas e nas populaçōes destes fungos no solo devem ser estudados.

Esses fungos sendo benéficos às plantas, portanto, torna-se necessário desenvolver manejo adequado de práticas agricolas, no sentido de que estes organismos nāo sejam afetados. Sendo relatado por TZEAN \& HUANG (1980), que em várias localidades da China, verificou-se baixa taxa de infecçāo micorrizica em raizes de citros, devido a aplicaçōes pesadas de defensivos agrícolas. A açāo dos herbicidas sobre os fungos micorrizicos é variável e diferentes espécies variam em sua sensibilidade, podendo em alguns casos suas formaçōes serem estimuladas, porém, este mecanismo deve ser melhor estudado, no entanto, provavelmente o processo esteja relacionado com o efeito dos produtos químicos e organismos antagónicos sobre o fungo micorrizico (SPOKES et alii, 1981).

Aplicaçōes de simazine em doses normais, segundo SMITH \& FERRY (1979), nāo inibiu o desenvolvimento do fungo micorrizico em Pinus sylvestris e Pinus nigra e, algumas vezes, aumentou a formaçāo micorrizica. O mesmo verificou-se com 
plântulas envasadas. Para os autores a resposta à simazine é também influenciada tanto pelos fatores climáticos como pelo tipo de solo.

Estudos realizados com o herbicida cianazine por GARCIA - ROMERA et alii (1988), sobre a infecçāo micorrizica em Pisum sativum mostraram que o efeito depressivo do herbicida ocorreu, quando se aplicou alta dose $(0,1 \mathrm{mg} / \mathrm{ml})$, porém, os autores consideraram este efeito mais em virtude da influência do herbicida no metabolismo da planta, do que uma açāo direta sobre o fungo.

Trabalho conduzido por OCAMPO \& HAYMAN (1980), com o herbicida chlortoluron em cevada, na dose de $2 \mathrm{Kg}$.i.a/ha, nāo observaram efeito do produto no número de esporos e nem na porcentagem de infecçāo micorrízica.

Utilizando os herbicidas flampropisopropyl, metoxuron e trifluralin e estudando os seus efeitos sobre a germinaçāo de esporos endomicorrízicos, TOMMERUP \& BRIGS (1981), observaram que a germinação dos esporos e o crescimento da hifa de Acaulospora laevis, Glomus coledonius e Glomus monosporus nāo foram alterados por trifluralin em doses 10 vezes acima da normal. Concluiram os autores que se estes herbicidas forem aplicados nas doses que nāo interferem no crescimento das plantas hospedeiras entāo, provavelmente, nāo afetarāo nenhum dos estágios do ciclo de vida do fungo micorrízico.

Ainda, SMITH et alif (1981), estudando o efeito de alguns herbicidas aplicados nas doses de 0,5 a 32 vezes a dose recomendada, verificaram que o diallate em altas doses, diminuiu a intensidade de infecçāo de raízes de trigo por fungos micorrízicos. Entretanto, esses autores concluiram que em aplicaçōes com doses normais, provavelmente a formaçāo e funçāo da simbiose nāo serāo afetadas.

Também, o herbicida paraquat foi estudado por POPES \& HOLT (1981) na dose de $2 \mathrm{Kg} . \mathrm{i} . \mathrm{a} / \mathrm{ha}$ (5 vezes a dose usual), sendo verificado reduçāo significativa na infecçāo de plântulas de Fraxinus americana L. inoculados com Glomus fasciculatus, observando-se ainda, reduçāo do total de hifas micorrizícas e número de vesículas. $\mathrm{Na}$ dose de 0,5Kg.i.a/ha, verificou-se tendência a favorecer o desenvolvimento de hifas, porém, nāo foi significativamente diferente do controle inoculado.

Este mesmo herbicida, estudado por SYLVIA \& SCHENCK (1982), na dose de 69g.i.a/ha, aumentou o número de esporos de Glomus mosseae e Gigaspora 
margarita em 24\% em Paspalum notatum Flügge, cultivado em solo com pH 6,5, sob condiçōes de casa de vegetaçāo. Mas, Glomus clarum, em solo com pH 4,5, foi suprimido pelo paraquat.

Baixos niveis na formaçāo de micorrizas do tipo vesículo-arbuscular foram observados por SCHWAB et alii (1982), em plantas de Chenopodium quinona WILLD após aplicaçāo de simazine em doses sub-letais, no entanto, atribuem os autores aos baixos niveis de formação devido o aumento de exsudatos radiculares como açucares e aminoácidos, concordando com a hipótese de SIQUEIRA (1983).

NEMEC \& TUCKER (1983), estudando os efeitos dos herbicidas bromacil, diuron, simazine, trifluralin, paraquat e lactofen em citros sob condiçoes de casa de vegetaçāo, verificaram que tanto o fungo Glomus etunicatus quanto o crescimento da planta, foram afetados adversamente pelos herbicidas paraquat, lactofen e simazine. Ainda, os mesmos autores estudando, só que em experimentos realizados nas condiçōes de campo, a mistura comercial de bromacil + diuron por um período de onze anos e simazine + paraquat por cinco anos, observaram uma ligeira redução na infecçāo micorrízica apenas para o tratamento simazine + paraquat, sugerindo que este efeito esteja mais relacionado à ação do paraquat sobre o fungo.

Por outro lado, SANTOS (1989) estudando os efeitos dos herbicidas terbacil, simazine, ametrine + secbumetone, dichlobenil, diuron, bromacil, bromacil + diuron, paraquat, glifosato e MSMA num trabalho conduzido por onze anos, nas condições de campo, não detectou diferenças significativas entre o controle e os tratamentos com estes herbicidas, tanto para o número de esporos como infecçāo micorrízica, discordando, em parte, dos resultados encontrados pelos autores citados anteriormente, com relação à molécula de paraquat.

Ainda, NEMEC \& TUCKER (1983), procurando identificar os herbicidas que poderiam ser utilizados com eficiência para o controle de determinadas plantas daninhas em citros, sem que no entanto apresentassem efeito inibitório sobre os fungos micorrízicos do tipo vesicular-arbuscular, encontraram o alachlor, diphenamid, napropamide, dichlofop e atrazina.

Após também, uma criteriosa revisão realizada por TRAPPE et alii (1984), sobre as reações dos fungos endomicorrízicos e de suas formaçōes na presença de 
defensivos agrícolas, dentre várias conclusōes tiradas, citam que se torna difícil traçar um perfil ideal para este tipo de estudo, por existir uma grande diversidade de culturas, diferentes condiçōes climáticas e grande número de produtos defensivos utilizados. Assim, sugerem que os pesquisadores envolvidos com trabalhos relacionados aos fungos micorrizicos, deveriam atuar em conjunto com especialistas em química orgânica, defensivos agrícolas e fisiologia de planta para que juntos, encontrem fundamento que direcionem a atividade desses químicos de utilizaçāo agrícola na natureza.

2.8. Efeito dos microrganismos sobre os herbicidas aplicados ao solo.

$\mathrm{Na}$ aplicação de agroquímicos, mais propriamente os herbicidas, objetiva-se o controle do mato que interferindo com as diferentes culturas reduz a produçāo agropecuária.

Com o uso intensivo destes produtos, surge a preocupação do homem em estudar o comportamento e destino final dos defensivos no solo, onde existe uma comunidade microbiana atuando sobre os mesmos, além de outros fatores ambientais.

No passado, em funçāo do pouco conhecimento nas diferentes áreas da ciência, mais propriamente a microbiologia do solo, atribuia-se que toda a degradaçāo de produtos químicos no solo era originada por microrganismos.

Estudos básicos permitiram um melhor entendimento das complexas reaçōes que ali ocorrem. Com o passar do tempo, este conceito foi sendo mudado, pois fatores físicos e químicos do solo, condiçōes climáticas e práticas agrícolas interferem e modificam o comportamento destes químicos no solo.

Quando se aplica um herbicida à superficie do solo, sabe-se que um ou mais dos seguintes fatores podem ocorrer: perdas por volatilizaçāo; degradaçāo fotoquímica; degradaçāo química; degradaçāo por microrganismos; adsorçāo por colóides do solo, biologicamente ativos ou inativos; precipitaçāo ou quelaçāo como complexos nāo disponiveis; perdas por lixiviaçāo; absorçāo e degradaçāo por plantas resistentes (Von HERTWIG et alii, 1974 e SOUZA, 1982). 
Dentre os fatores citados, a degradaçāo de um defensivo pela açāo dos microrganismos do solo é a mais significativa.

O grau de intensidade com que um defensivo é ativado ou inativado, móvel ou imóvel, pouco persistente ou muito persistente, absorvido pela planta, adsorvido pelos colóides do solo dependerá basicamente do metabolismo dos microrganismos do solo. Desta forma, quando se estuda o comportamento de um defensivo no solo é imperativo que se leve em consideração a comunidade microbiana do solo..

Este aspecto é considerado por vários pesquisadores que confirmam a importância da decomposição microbiana dos defensivos no solo, afetando o comportamento e a degradaçāo dos mesmos de uma maneira muito intensa (ALEXANDER, 1965 e 1977; UPCHURCH, 1966 e KAUFMAN \& KEARNEY, 1976).

Os microrganismos do solo podem agir sobre os defensivos de diversas formas. Um mecanismo pode envolver degradaçāo com posterior destoxicaçāo e ou metabolizaçāo do defensivo, enquanto que outro mecanismo pode envolver a transformaçāo de uma molécula tóxica em produto que exerça alguma influência benéfica sobre plantas superiores, fauna do solo ou microrganismos (KAUFMAN \& KEARNEY, 1970).

As populaçōes microbianas do solo sāo influenciadas pelo teor de matéria orgânica, conteúdo de umidade, temperatura, $\mathrm{pH}, \mathrm{CTC}$, aeraçāo e outros inúmeros parâmetros do solo. Parâmetros esses ,também envolvidos nos processos físicos e químicos de degradaçāo dos herbicidas, o que muitas vezes dificultam na diferenciaçāo entre os processos que estejam atuando na degradaçāo do defensivo no solo, quer seja químico, físico ou biológico (KAUFMAN \& KEARNEY, 1976).

Para que ocorra uma rápida decomposiçāo dos herbicidas aplicados ao solo, alguns fatores devem dar condiçōes ótimas para um bom desenvolvimento da populaçāo microbiana do solo tais como: umidade do solo entre 50 a $100 \%$ da capacidade de campo, solo bem aerado, temperatura entre 27 a $32^{\circ} \mathrm{C}, \mathrm{pH}$ de 6,5 a 8,0 e altos teores de matéria orgânica (ALEXANDER, 1965 e 1977; Von HERTWIG et alii, 1974).

Ainda, segundo os mesmos autores a decomposiçāo microbiana dos herbicidas ocorre predominantemente na camada dos $30 \mathrm{~cm}$ superficiais do solo. 
Os efeitos da umidade do solo sobre os microrganismos e sua influência na degradaçāo de herbicidas foram observadas por OU (1984), realizando um trabalho onde constatou que a tensão de água no solo, ou o conteúdo de água e a temperatura do solo influenciaram a atividade microbiológica e, em contrapartida influenciando a taxa de degradação dos defensivos nos solos. Neste trabalho, encontrou também que a degradaçao microbiana do 2.4-D foi rápida quando o solo foi submetido a uma tensāo de umidade de 1/3 atm e lenta quando seco (15 atm).

A aplicação de um herbicida no solo resulta em um ajustamento da população microbiana no solo. Este ajustamento é conhecido como "fase lag", e se dá possivelmente, de uma a duas semanas após a aplicação, onde a concentração do herbicida nāo é afetada significativamente. Entretanto, dependendo das características físico-químicas do solo e do herbicida uma pequena quantidade do mesmo é removida através da adsorçāo pelos colóides do solo, (ALEXANDER, 1965 e KAUFMAN \& KEARNEY, 1976).

A extensão da "fase lag" é influenciada principalmente pela natureza química do herbicida, mas pode também ser influenciada por outros fatores como concentração do produto e tipo de solo. Durante esta fase, há um pequeno ou quase nulo crescimento dos microrganismos, porém, chegando-se ao final da mesma, os microrganismos começam a crescer em número, e se proliferam em abundância. Portanto, o período em que os microrganismos se proliferam na taxa máxima, aumentando sua população em progressāo geométrica é conhecida como fase logarítmica ou fase de crescimento, ocorrendo durante esta fase a utilização mais rápida do herbicida (KAUFMAN \& KEARNEY, 1976).

Ainda, citam os autores que dependendo da disponibilidade do substrato, ou que o espaço físico se torne limitante ou que as substâncias tóxicas se acumulem, os microrganismos param de se multiplicar numa razāo geométrica e a taxa de divisāo celular diminui. Finalmente, o número de células em divisāo se igualam ao número de células que morrem, e a população microbiana entra numa fase estacionária ou de repouso. Quando se adiciona uma nova quantidade de substrato nesta fase os microrganismos irāo se proliferar, nāo ocorrendo uma nova "fase-lag" ou sendo esta fase muito reduzida. 
As mudanças fisiológicas e bioquímicas que ocorrem na população microbiana durante a "fase lag", na presença de herbicidas levanta dúvidas entre os pesquisadores, segundo AUDUS², citado por KAUFMAN \& KEARNEY (1976) que propõe duas hipóteses. A primeira é a de que ocorrem mudanças genéticas nos microrganismos tornando-os aptos a degradar os herbicidas, teoria esta seguida por ANDERSON (1977).

A segunda hipótese é a da formação de enzimas induzidas. Essas enzimas são consideradas, induzidas, pois não foram encontradas em células dos microrganismos em culturas na ausência de herbicidas.

Aplicaçōes repetidas de 2.4-D e MCPA resultaram numa diminuição do tempo de degradaçāo que passou de 10 semanas para o 2,4-D e 20 semanas para o MCPA após uma aplicação, para 4 e 7 semanas, respectivamente, após 19 anos de aplicaçōes anuais. Verificou-se ainda, que apesar do aumento da capacidade da microflora do solo em degradar esses herbicidas, nāo houve mudança no número de microrganismos presentes no solo (TORSTENSSON et alii, 1974).

Alguns herbicidas como o 2,4,5-T tem uma biodegradação muito lenta e não apresentam uma "fase lag" muito clara (ALEXANDER, 1965).

Diversos microrganismos são envolvidos no processo de degradação dos defensivos no solo. A degradação causada por bactérias ocorre principalmente com herbicidas que tem um maior grau de solubilidade em água e que não estejam fortemente adsorvidos, enquanto que os fungos metabolizam justamente os herbicidas menos solúveis em água e os mais adsonidos. A razão disso é que a forma de reprodução por fissāo binária das bactérias permite que elas compitam mais sucessivamente por substrato prontamente utilizável, enquanto que o crescimento dos micélios dos fungos permitem que as partículas do solo sejam encapsuladas e penetradas, entrando então em contato com o herbicida ali adsonvido (KAUFMAN \& KEARNEY, 1976).

Diversos estudos têm relacionado os microrganismos ativos com a habilidade em degradar os herbicidas. Numa revisão dos mesmos autores citados anteriormente 
e, em outra realizada por ALEXANDER (1965), os seguintes herbicidas e respectivos organismos ativos, são citados como agentes decompositores dos mesmos: 2,4-D (Arthrobacter globiforme; Achromobacter; Flavobacterium; Pseudomonas; Corynebacterium e Mycoplana); dalapon ( Alternaria sp; Nocardia; Pseudomonas; Streptomyces aureofaciens; Pseudomonas dehalogenans; Arthrobacter; Agrobacterium; Bacillus; Penicillium e Conynebacterium spp); 2,4-DB (Flavobacterium e Nocardia opaca); MCPA (Achromobacter; Pseudomonas; Corynebacterium e Mycoplana); MCPB (Nocardia opaca); Monuron (Pseudomonas spp); TCA (Micromonospora; Psedomonas; Agrobacterium e Arthrobacter); 2,4,5-T (Achromobacter; ConynebacteriumeFlavobacterium); DNOC(Corynebacterium); IPC (Corynebacterium); CIPC (Corynebacterium); 2,3,6-TBA (Pseudomonas) e DNBP (Corynebacterium; Pseudomonas).

Também CHAHAL et alii (1976) estudando a degradaçāo do alachlor, isolaram um Penicillium sp e um Trichoderma sp em solo previamente tratado com esse herbicida, observaram a presença desses fungos degradando o alachlor.

Investigaçōes de MOORE et alii (1983) demonstraram que o glifosato é completamente degradado pelos microrganismos do solo. Usaram neste trabalho uma raça de bactéria que utiliza rápida e eficientemente o herbicida como fonte de fósforo num meio sintético.

Diz KAUFMAN (1974) que a detecçāo de pequenas quantias de ${ }^{14} \mathrm{CO}_{2}$ liberadas do carbonil ${ }^{14} \mathrm{C}$-lábil do solo tratado com picloram poderiam ser considerados indicativo de descarboxilaçāo como uma possivel reaçāo de degradaçāo:

Em relaçāo ao aumento do número de microrganismos do solo, FOURNIER (1981) afirma que o tratamento do solo com 2,4-D resultou num leve aumento no número de microrganismos metabolizadores. Também, FOURNIER et alii (1982) mencionaram que o número de microrganismos aumentou com a elevaçāo da concentraçāo do herbicida, os quais sāo capazes de usar o 2,4-D como fonte de carbono.

BELLINCK et alii (1979) observaram que a mineralização do 2,4-D aplicado a 10 ppm foi iniciada imediatamente após a sua aplicação no solo. Às altas concentraçōes houve um período de atraso e que os minerais $P-K$ inibiram a mineralizaçāo do 2,4-D, 
enquanto a combinaçāo CaMg e aqueles que contém $\mathrm{N}$ a ativaram. Quando 500ppm de 2,4-D foram aplicados, observou-se a formação de uma flora zimógena que foi muito ativa na descarboxilação do herbicida, mas incapaz de romper o anel aromático da molécula do herbicida: Estes microrganismos provavelmente pertencem ao gênero Arthrobacter e Pseudomonas.

A suscetibilidade à decomposição microbiana dos herbicidas com anéis fenílicos na sua estrutura, segundo ANDERSON (1977) é diminuída conforme se aumenta o número de átomos de halogênios $(F, C l, B r, l)$ ligados ao anel fenílico.

UPCHURCH (1966) afirma que dentro de uma classe de compostos a configuração molecular pode exercer uma influência dominante na capacidade dos microrganismos de degradar um produto químico específico. A halogenizaçāo dos ácidos fenoxialifáticos ou dos diclorofenóis da posição meta ao grupo oxi aumenta a resistência a biodegradação. Também adicionando-se um radical fenoxi ao ácidoalifático através do átomo de carbono alfa, tem-se uma influência semelhante.

Concluindo, ALEXANDER (1965) cita duas características associadas à resistência dos compostos fenóxicos à biodegradaçāo: o tipo de ligação do ácido alifático no anel e a posição dos cloros no anel. Os compostos que possuem o cloro na posição meta do anel não são metabolizados com tanta eficiência.

\subsection{Efeitos dos herbicidas sobre os microrganismos do solo}

\subsubsection{Efeitos sobre bactérias, fungos e actinomicetos}

É de conhecimento geral, que os herbicidas contribuem sobremaneira para a manutençāo da produção agrícola, deixando a cultura livre da concorrência das plantas daninhas.

A ação destes herbicidas, entretanto, não se limitou ao objetivo imediato de matar, ou não permitir a germinação de uma determinada espécie de planta daninha. Tem sido relatado por AUDUS $^{3}$, citado por CHAHAL et alii (1976) constituir-se numa

${ }^{3}$ AUDUS, L.J. The Physiology and Biochemistry of Herbicides. New York and London, Academic Press, p. 163-206. 1964. 
séria ameaça ao equilíbrio dinâmico da populaçāo do solo e ainda na fertilidade do mesmo.

Os trabalhos de FRYER \& KIRKLAND (1970) em experimento de campo com MCPA, triallate, simazine e linuron, amostrados regularmente de 1964-67, para análises químicas do solo, mostraram que as maiores alteraçōes foram causadas pelos herbicidas nos níveis de potássio disponível, nitrato, amónio, fósforo disponivel e pH.

Estudando os efeitos de alguns herbicidas na atividade microbiana do solo, LEWIS et alii (1978) sugeriram que os herbicidas nas doses utilizadas na agricultura nāo afetam a atividade microbiana da microflora do solo, e GROSSBARD \& MARSH (1974) estudando os efeitos de sete herbicidas do grupo das uréias substituidas na microflora também observou que algumas uréias substituídas podem exercer influência na populaçāo e atividade da microflora do solo, mas somente a altas concentraçōes, constatando VUKHRER \& KAPLUN (1981) que o fluometuron e a trifluralina nāo afetaram os microrganismos aeróbicos, porém o dalapon inibiu o crescimento de todos os grupos, especialmente anaeróbicos.

Trabalhando com terbacil sobre a biomassa microbiana do solo e de laboratório, ROSLYCKY (1981) observou em concentraçōes de até $700 \mathrm{mg} / \mathrm{g}$ de substrato, pouco efeito na populaçāo bacteriana tanto sob condiçōes de campo como em laboratório, nāo se verificando efeitos no crescimento "in vitro" de cento e onze estirpes de microrganismọs de importância agrícola incluindo bactérias.

Também, HUGE (1981/2) analisando o efeito do methabenzthiazuron sobre os microrganismos de três tipos de solo, após um período de cinco e oito anos, observou que o número de bactérias nāo foi afetado significativamente. No entanto, COLE (1976) estudando o efeito da aplicaçāo de atrazina por um período de 9 anos em solo cultivado com milho, observou pequeno efeito desse herbicida sobre os microrganismos, porém, mesmo tendo havido uma inibição parcial no crescimento bacteriano durante a primeira semana, após a primeira aplicaçāo, o número de bactérias viáveis nāo foi prejudicado depois de repetidas aplicaçōes.

Efeitos variáveis, incluindo aumentos e decréșcimos transitórios no número de bactérias, foram observados por MUDD et alii (1985) estudando o isoproturon na dose 
de 2,5 Kg.i.a./ha, na rizosfera de trigo. Entretanto, em laboratório, o herbicida nāo afetou culturas puras de bactérias em concentraçōes de 1-60 mg.i.a/ml.

Trabalhando com a molécula de paraquat, TU \& BOLLEN (1968) constataram que a mesma diminuiu a camada vegetal total como as populaçōes bacterianas em solo areno-siltoso, contudo nāo apresentou nenhuma influência significativa na atividade microbiana de importáncia para a fertilidade do solo. BELLINCK \& MAYAUDON (1978) observaram que o phenmedipham e seus derivados aplicados a uma concentraçāo de 10 ppm teve pequena influência na flora bacteriana, no entanto, causou aumento no número de actinomicetos e fungos.

Procurando-se ainda verificar a açāo dos herbicidas no meio ambiente AU (1968) estudando o efeito do endotal, pentaclorofenoato de sódio e TD-47 na populaçāo microbiana, amonificaçāo, nitrificaçāo e respiraçāo de seis solos diferentes, constatouse que o endotal a 20 e 200 ppm nāo apresentou nenhum efeito nos fatores acima citados, entretanto, nos tratamentos com Na-PCP a 40 ppm e combinado com endotal observou-se efeito supressivo. O TD-47 a 100 ppm teve um efeito estimulatório nas bactérias em solos arenosos.

Estudando-se o efeito de 25 herbicidas e combinaçōes de herbicidas em doses comparáveis às usadas na agricultura, LEWIS et alii (1978) observaram que os herbicidas nāo afetam a respiração e que o dinoseb reduziu a população de algas do solo arenoso em mais de $90 \%$, a trifluralina, linuron e metribuzin nāo as reduziu.

Utilizando-se as formulaçōes comerciais de avadex e avadex BW misturados com carbonil C dialate e alil-2C-trialate, respectivamente, ANDERSON (1984) constatou que nos solos estudados para ambos herbicidas, as taxas de degradaçāo relacionaramse à biomassa e que a adiçāo de nutrientes e celulose aos solos causou aumento imediato da biomassa microbiana e, em solos nāo corrigidos esta diminuiu com o tempo.

Estudando as interaçōes entre solo-microrganismo e paraquat, TU \& BOLLEN (1968) observaram que na concentraçāo de 10 ppm o paraquat atuou como fonte só de carbono, e em concentraçōes superiores o herbicida foi aparentemente tóxico. 0 paraquat serviu como única fonte de nitrogênio para certas bactérias. 
Sabe-se que muitos fungos do solo exibem um alto grau de tolerância a herbicidas, mas isto não implica que eles sejam inafetados totalmente.

TRAPPE et alii (1984) observaram que os fungos micorrizicos e a formação de micorrizas podem ser drasticamente afetados por alguns herbicidas. Com raras exceçōes as concentraçōes de herbicidas necessárias para afetar o crescimento dos fungos segundo os mesmos autores, foram consideravelmente maiores do que as recomendadas, verificando-se para a atrazina e 2,4-D reduçāo na formaçāo de ectomicorriza.

Comenta ANDERSON (1978) que o 2,4-D a 400 ppm inibiu Penicillium herquei, Fusarium nivale, Theilavia terricola e Cunninghamella echinulata, mas a baixas concentraçōes nāo teve efeito. O crescimento micelial do Parcilomyces varioti, Aspergillus niger, Aspergillus flavus, Aspergillus tamarii e Penicillium funiculosum em cultura líquida foi estimulado por 2,4-D (5-20 ppm) e MCPA (5-20 ppm) e o último composto aumentou a atividade no Aspergillus flavus e Aspergillus niger e a atividade da urease no Aspergillus tamarii. Afirma também, que se verificou ao adicionar 220 ppm de 2,4-D, aumento na síntese de ácido nucleico em 140\%.

Ainda, o mesmo autor estudou os efeitos de 2,4-D e paraquat em 20 fungos em cultura, descobrindo que o 2,4-D a 30 e 60 ppm, freqũentemente estimulou 0 crescimento do fungo, que somente foi inibido a 120 e 250 ppm.

Nos trabalhos de DESHMUKH \& SHRIKHANDE (1974) usando-se os herbicidas 2,4-D, T.C.A., simazine, atrazine e cianazine observaram que os herbicidas em geral em suas doses normais parecem nāo afetar o balanço biológico da microflora do solo, exceto o éster de 2,4-D que inibiu a bactéria nos tratamentos pré-emergentes durante os primeiros 10 dias de incubação. Todos os herbicidas, tanto na aplicaçāo em préemergencia, como em pós-emergencia, diminuíram a populaçāo fúngica nos primeiros dez dias, com exceção do 2,4-D, mas posteriormente estes organismos cresceram normalmente.

Comparando-se a contagem de propágulos fúngicos total no solo, estes são menos frequentes que bactérias e actinomicetos. Segundo GROSSBARD (1976), a estimulação dos fungos, especialmente em cultura pura, pode ser devido a utilizaçāo 
do herbicida pelo fungo, como uma fonte de nutriente. Nesses casos a composiçāo do meio de cultura, pode também afetar grandemente $\circ$ grau de toxicidade.

Estudando o efeito do propyzamide sobre a colonizaçāo de um substrato por Trichoderma harzianum em presença de outros fungos do solo, DAVET (1981) observou que o desenvolvimento desse microrganismo foi raramente modificado pelo herbicida.

Populaçōes de fungos mostraram-se bem resistentes ao bentazon nas concentraçōes de 10 a 100 ppm em dois tipos de solos. Essa resistência foi maior notadamente em solo com um alto teor de matéria orgánica (MARSH et alii, 1978).

BREAZEALE \& CAMPER (1970) observaram que o número de colónias de fungos em amostras de solos que receberam repetidas aplicaçōes do herbicida trifluralin durante $\mathrm{o}$ ano, foi menor que na amostra controle. Entretanto, o herbicida 2,4D nāo afetou o número de microrganismos.

Os efeitos do simazine sobre o fungo Aspergillus niger na solubilizaçāo do fósforo em solos calcáreos, foi estudado por ORTUNO et alii (1978) sendo constatado que o herbicida autoregulou o crescimento do fungo, inibindo-o ou estimulando-o, obedecendo uma equaçāo de regressāo.

A esporulaçāo de determinados fungos em presença dos herbicidas prometryne, diuron, fluometuron e MSMA nas concentraçōes de $0,10^{*}, 10^{\text {s }}$ e $10^{-4} \mathrm{M}$ foi estudada por DAVIS et alii (1976), os quais observaram para a concentraçāo $10^{4} \mathrm{M}$ desses herbicidas que aumentou o número de esporos do fungo Trichoderma viride, na ordem de 20, 30,35 e $50 \%$ respectivamente. Verificou-se também, semelhante tendência para o fungo Asspergillus terreus.

Num estudo quantitativo com fungos, isolados de solo cultivado com três níveis de atrazine, crescidos em meio de cultura, WACHA \& TIFFANY (1979) procedendo a contagem em placas, observaram que os gêneros mais frequentes eram Trichoderma, Fusarium, Penicillium, Gliocadium e Rhizopus.

Trabalhando com os herbicidas bentazon, fluchloralin, prometrine, terbutrine, alachlor, linuron, oxidiazon, terbacil, pendimethalin, methabenzthiazuron, 2,4-D, diuron, benthiocarb, atrazine e simazine associados a três fungos Rhizoctonia bataticola, Sclerotium rolfsii e Fusarium oxysporum, VERMA et alii (1979) observaram 
considerável redução no crescimento das hifas, particularmente pelo benthiocarb, methabenzthiazuron e linuron. Por sua vez, a atrazine impediu a formaçāo de esclerócio pelo Sclerotium rolfsii.

DUAH-YENTUMI \& JOHNSON (1986) estudando os efeitos de repetidas aplicaçōes de herbicidas em solos, observaram que a simazina não apresentou nenhum efeito sensivel sobre a microflora, entretanto o paraquat diminuiu significativamente a massa microbiana, principalmente a biomassa fúngica.

Ainda, com relação aos fungos, vários herbicidas, entre eles o terbacil, 2,4-D, bentazon, nāo tiveram efeitos adversos sobre a populaçāo de fungos, contudo, herbicidas como o paraquat, em fungos celulolíticos estimulou o crescimento no solo, mas quando aplicados à celulose, contribuiu para uma diminuição; o mesmo ocorrendo para outros fungos (SMITH \& FERRY (1979)).

Os actinomicetos têm sido investigados numa extensão relativamente pequena considerando sua contribuição importante no equilíbrio das espécies, relaçōes antagônicas e na degradação da matéria orgânica do solo (GROSSBARD, 1976).

Revendo trabalhos de contagens de propágulos de actinomicetos no solo, 0 mesmo autor cita que doses de 8 e $10 \mathrm{~kg} / \mathrm{ha}$ de atrazine estimularam actinomicetos celulolíticos após uma inibiçāo inicial.

ROSLYCKY (1981) verificou que a respiração da biomassa microbiana total do solo foi afetada por altas concentraçōes de terbacil, entretanto até $500 \mu \mathrm{g} / \mathrm{ml}$ mostrou um estímulo na respiração de actinomicetos, e que a $600 \mu \mathrm{g} / \mathrm{ml}$ a inibição foi parcial.

Em alguns casos os resultados obtidos por pesquisadores independentes, sāo conflitantes.

Observa-se uma evoluçāo marcante na estrutura, formulaçāo e atividade dos herbicidas para o objetivo proposto que é o de maximizar sua eficiência no controle das plantas daninhas. Segundo ANDERSON (1978) este avanço assumiu um aspecto consideravelmente significativo, nos últimos anos, referente aos efeitos da evoluçāo molecular nos organismos alvos e que ainda não se estenderam aos microrganismos, os quais podem ser afetados positiva ou negativamente.

Os fatores para esse autor que influenciam os efeitos dos defensivos nos microrganismos não objetivos sāo: a) variabilidade do solo: a textura, conteúdo de 
argila mineral, matéria orgânica, $\mathrm{pH}$, condutividade e capacidade de retençăo de umidade dos solos sāo conhecidos por variar consideravelmente com regiōes geográficas; b) prática agronômica e cobertura de plantas: nos solos de mesma classe química e geológica, o tipo de cobertura de plantas deve influenciar na composiçāo da biomassa do solo.

Há diferenças consideráveis entre solos cultivados e nāo cultivados e isto se deve indubitavelmente à presença de uma açāo ativa da rizosfera em solo cultivado. O cultivo, araçāo para incorporaçāo dos residuos de cultura geralmente acelera a decomposiçāo microbiana da matéria orgânica, entretanto, os resíduos acumulados no solo favorecem a lenta oxidação.

Em essência, as variaçōes nas composiçōes das estirpes e espécies microbi anas que são determinadas pelos tipos e condiçōes de solo, práticas agronômicas e populaçōes de plantas presentes na área devem ser importantes na determinação da populaçāo da biomassa microbiana; c) formulaçāo dos defensivos: a forma em que o defensivo é aplicado ao solo é especialmente importante. Usando-se a formulação comercial, o investigador nunca pode estar certo, se os aditivos da formulação são responsáveis por algumas das trocas na atividade microbiana ou nāo. Os chamados ingredientes, como a caolinita pura, devem afetar os microrganismos do solo; d) tipo de defensivo e método de aplicação: a diferença entre os defensivos sistêmicos e nāo sistêmicos devem ser de importância considerável no éxito da determinaçāo das investigaçōes nos seus efeitos nos microrganismos do solo.

Nas aplicaçōes em pós-emergencia, muito pouco de um fungicida ou herbicida pode contactar totalmente a superfície do solo. A maior parte do material permanece nas folhas. Este material pode ser incorporado ao solo, mas mudanças significativas devem ocorrer na química neste interim.

\subsubsection{Efeitos na amonificação e nitrificação}

O processo de nitrificação ou amonificação consiste na conversāo pelos microrganismos heterotróficos do nitrogênio orgânico a amônia. A amônia sofrendo transformaçōes adicionais na presença de íons hidrogênios e microrganismos 
quimiautotróficos, em ambiente aeróbico, passa a nitrato, processo este conhecido como nitrificação, ambos processos diretamente relacionados às atividades agronômicas.

Para ANDERSON (1978) a amonificação tem um papel importante a ser observado. Sem a amonificaçāo, a nitrificaçāo seria severamente limitada aos ions de $\mathrm{NO}_{3}$; entretanto, segundo o autor em muitos casos a amonificaçāo é estimulada por aplicaçōes de herbicidas, cujo fato nāo surpreende, desde que a morte das plantas e possivelmente a maior parte de suas populaçōes da rizosfera resultem em um aumento na proteina disponivel para estas transformaçōes. Citando ainda que somente a altas concentraçōes de herbicidas inibiu a amonificaçāo e concentraçōes de 100-250 ppm nāo apresentou nenhum efeito, com exceçāo do linuron que foi tóxico a baixas concentraçōes.

TU \& BOLLEN (1968) estudando a influência do paraquat na atividade microbiana de quatro tipos de solo, observaram que a amonificaçāo foi levemente retardada. Mas, citam que se o herbicida for utilizado de acordo com as instruçōes recomendadas, não afetará as atividades dos microrganismos do solo.

Uma pesquisa interessante para estudar os efeitos dos herbicidas na nitrificaçāo do solo foi realizada por DOMSCH \& PAUL (1974). Testando os efeitos de 35 herbicidas por meio de modelos experimentais e matemáticos, concluiram que a maioria dos herbicidas tinham um efeito negligenciável às aplicaçōes normais de campo e a nitrificaçāo foi efetiva novamente quando o pH estava abaixo de 7,0. A oxidaçāo do $\mathrm{NO}_{2}$ para $\mathrm{NO}_{3}$ pareceu ser mais sensivel do que a oxidação do $\mathrm{NH}_{3}$ para $\mathrm{NO}_{2}$.

RODES et alii (1980) discutindo o efeito da hexazinone nas populaçōes bacterianas, fúngicas e nitrificantes do solo, concluiram que a adiçāo de 10 ppm de hexazinone nos três solos agrícolas estudados, nāo reduziu a população dos fungos ou bactérias durante 8 semanas do período de teste e que a adição de 5 e 20 ppm de hexazinone nāo teve efeito no processo de nitrificação durante o período de teste de 5 semanas.

Examinando os efeitos dos defensivos agrícolas sobre o Nitrobacter agilis, WINELY \& CLEMENTE SAN (1970) verificaram que a bactéria foi inibida pelo CIPC a 10 $\mu \mathrm{g} / \mathrm{ml}$, porém, não foi pela simazine. 
Os herbicidas dalapon, pyrazon e trifluralin, na concentraçāo de 100 ppm, nāo apresentaram efeitos adversos à mineralização do nitrogênio em dois tipos de solos. No entanto, em um deles, a nitrificação foi inibida nas três primeiras semanas pelo dalapon e pyrazon (DAVIES \& MARSH, 1977).

Solos incubados com o herbicida dalapon-sódio e analisados periodicamente para $\mathrm{NH}_{4}^{+}$e $\mathrm{NO}_{3}$; mostraram um retardamento nos processos de nitrificaçāo (oito semanas) e desnitrificação (doze semanas) (WEERARATNA, 1980).

Estudando por um período de 7-8 anos os efeitos de aplicaçōes anuais dos herbicidas MCPA, triallate, simazine e linuron sobre a nitrificação do solo, GROSSBARD (1971) observou que os efeitos negativos causados pelo linuron e simazine relacionavam-se à diferença na quantidade de matéria orgânica mais prontamente degradável.

Os herbicidas CIPC, monuron e seus efeitos sobre a nitrificação foram estudados por HALE et alii (1957), verificando-se que na concentraçāo de 8 ppm o CIPC inibiu completamente o crescimento dos microrganismos nitrificantes. Com o monuron, este fato não ocorreu até a concentração de 40 ppm.

Trabalhando em laboratório com os herbicidas chloroxuron, metobromuron e fluormeturon, nas concentraçōes de 0, 0.25, 0.5, 1 e 2 ppm, AMAKIRI (1977) observou que os efeitos foram variáveis sobre a populaçāo de Nitrosomonas e Nitrobacter. Verificou-se ainda que o chloroxuron diminuiu o crescimento inicial com novo estimulo de crescimento no sétimo dia, enquanto que o metobromuron diminuiu o crescimento após o sétimo dia. Contudo o fluometuron apresentou efeitos alternados de crescimento e redução populacional.

\subsubsection{Efeitos na denitrificação}

Denitrificação ou redução do nitrato ou nitrito, é uma atividade comum e importante no solo, o qual se processa enzimaticamente pela redutase (MALAVOLTA et alii, 1974), constituindo-se no processo pelo qual o nitrogênio fixado do ar por via industrial ou biológica, é devolvido a atmosfera. 
Os trabalhos de HART \& LARSON (1966) estudando o efeito do 2,4-D de 0,221 a 1,105 ppm, no desenvolvimento de 3 bactérias denitrificantes perceberam que 0 crescimento aeróbico foi menos afetado do que o crescimento anaeróbico com NO como receptor de elétron. A Pseudomonas denitrificans toi menos sensivel ao 2,4-D do que a Ackromobacter nephridii ou Pseudomonas stutzeri. Experimentos manométricos para comparar os efeitos do 2,4-D na reduçāo do $\mathrm{NO}_{3}$; para $\mathrm{NO}_{2}$; pelo descanso das células de Pseudomonas denitrificans mostrou que quando o $\mathrm{NO}_{3}$; agiu como receptor de elétron a taxa de formaçāo do gás foi diminuída de 50 e $100 \%$ nas concentraçōes de 0,77 e 1,56 ppm de 2,4-D, respectivamente. Porém, quando o $\mathrm{NO}_{2}$ : foi usado como receptor de elétron, a produçāo de gás ocorreu na concentraçāo de 2,3 ppm de 2,4-D, mas a taxa de produçāo foi diminuída. Os dados demonstraram também que diferentes bactérias apresentam variaçōes sensiveis para este herbicida e que alguma correlaçāo existe entre a resposta do 2,4-D e do conteúdo de enzima e fisiologia dos microrganismos.

\subsubsection{Efeitos nos fixadores de nitrogênio}

A importância de determinar se os herbicidas e outros agroquímicos afetam a nodulaçāo, agora assume um papel económico relevante, pois poucos pesquisadores estudaram estes aspectos dos diferentes herbicidas existentes.

Afirma ANDERSON (1978) que o Rhizobium leguminosarum mostrou uma diminuiçāo no crescimento com 50 ppm de 2,4-D, mas 250 ppm foi necessário para uma diminuiçāo significante no crescimento do Rhizobium meliloti e Bradyrhizobium japonicum. Alguns tipos de Rhizobium toleraram 2,4-D a 300 ppm e o crescimento do Rhizobium meliloti, Rhizobium trifolii, Rhizobium leguminosarum e Rhizobium phaseoli foi inibido com 5 a 300 ppm de MCPA, MCPB ou 2,4-D.

Para o mesmo autor a supressāo temporária do crescimento do Rhizobium sp. foi obtido com taxas de 50 a 100 ppm de 2,4-D, mas foi necessário mais de 500 ppm para completar a inibição.

Cita ainda que os três herbicidas mais tóxicos foram linuron, diuron, dinoseb e a mistura de profan+diuron, os quais foram tóxicos a várias centenas de ppm. 
Também, LENHARD (1959) estudando o efeito do 2,4-D em certos aspectos fisiológicos dos microrganismos do solo, mencionou que a microflora do solo nāo foi seriamente afetada pela aplicaçāo de 2,4-D acima de 100 ppm, e em concentraçōes superiores a 500 ppm as colónias de bactérias perderam sua estrutura normal, observando-se que a fixação de nitrogênio pelo azotobacter diminuiu rapidamente.

DEUBER \& FORSTER (1978) estudando a influência do EPTC na nodulaçāo natural do feijāo Phaseolus vulgaris L. em três experimentos conduzidos no campo, nāo verificaram diferenças significativas no número e peso de nódulos para todas as doses aplicadas. Também, na soja plantada 1, 7 e 90 dias após aplicação de dalapon, não se verificou redução da nodulaçāo, mesmo em doses altas (WORSHAM \& GIDDENS, 1957).

Posteriormente, trabalhando com a mesma cultura citada acima, nas condiçōes de campo, com os herbicidas linuron, alachlor, napropamide, trifluralin e vernolate MASSARIOL \& LAM-SANCHEZ (1974) nāo encontraram efeitos prejudiciais desses herbicidas sobre a nodulaçāo.

Estudando a influência de diferentes doses de amitrole sobre Rhizobium leguminosarum, Rhizobium lupinii e Rhizobium meliloti, RODRIGUEZ \& MATE (1980) observaram que essas espécies toleraram 1000 ppm do herbicida, e que o crescimento começou a diminuir na concentraçāo de 5000 ppm. Nessa concentraçāo o Rhizobium Iupinii foi quem demonstrou menor alteraçāo.

Os herbicidas dinoseb, trifluralin, nitralin, dinitramine e linuron aplicados em préemergência na cultura da soja, foram estudados por ALAA-ELDIN et alii (1981). Os autores constataram que o dinoseb na dose recomendada e trifluralin na dose 5 vezes a recomendada, estimularam a nodulação e a atividade da nitrogenase, enquanto 0 nitralin, dinoseb e linuron em altas doses inibiram a formaçāo de nódulos. Onde se conclui que nas doses recomendadas, esses herbicidas nāo interferem na formaçāo de nódulos na cultura da soja.

Ainda, GIARDINI et alii (1979) estudando o efeito dos herbicidas trifluralin, vernolate, alachlor e duas doses de nitrogênio, na nodulaçāo da soja, CV Santa Rosa, por dois anos consecutivos, verificaram que esses herbicidas não influenciaram a nodulação aos 35, 58 e 98 dias após o plantio. Também, LORENZI \& ARAUJO (1974), 
estudando o efeito de vários herbicidas na nodulaçāo da soja, CV Davis, observaram que trifluralin e alachlor nāo influenciaram a nodulação causada pela estirpe inoculada à semente, porém o tríluralin afetou a nodulação causada por bactérias nativas do solo.

\subsubsection{Efeitos nas algas do solo}

Sabe-se que as algas do solo são, via de regra, afetadas sensivelmente por quase todos os herbicidas.

Essa sensibilidade, contudo é menos marcante no solo que em meio líquido. De comum a outros grupos microbianos, as respostas das algas do solo variam com - tipo de solo. As algas também podem adquirir resistência aos herbicidas (GROSSBARD, 1976).

ANDERSON (1978) comenta que o amitrole, atrazina, monuron e diuron a $18 \mathrm{e}$ 55 ppm inibiu a alga do solo mais prontamente em cultura do que no solo, e que somente altas doses de simazine inibiram culturas de algas isoladas da rizosfera do milho, tendo a propazine efeito variável em várias raças de algas do solo. Por outro lado, cita que na presença de 1220 ppm de 2,4-D, Chlorella pyrenoidosa desenvolveu vesiculaçāo da membrana do plasma, inchamento e desorganizaçāo da crista mitocondrial e rompimento no sistema cloroplasto lamelar.

Utilizando os herbicidas 2,4-D, trifluralin, MCPA e TCA, aplicados em dois niveis de concentração, CULLIMORE \& MCCANN (1977) observaram que dos 31 gêneros identificados, apenas as algas Chlamydomonas, Chlorococcum, Hormidium, Palmella e Uluthrix apresentaram alta sensibilidade a esses herbicidas. As mais resistentes foram Chlorella, Lyngbya, Nostoc e Hantzschia.

O fluometuron suprimiu o crescimento autotrófico de Chlorella pyrenoidosa e Euglena gracilis, deixando de existir o efeito inibitório quando a alga cresceu heterotróficamente (SIKKA \& PRAMER, 1968). O herbicida não afetou a respiraçāo das algas, mas afetou o despreendimento de oxigênio fotossintético. A conclusão a que chegaram os autores, é de que esse herbicida é tóxico para uma ou mais reaçōes controladas pela luz, entretanto, o seu efeito é seletivo para as reaçōes no escuro, que precederem a fase clara da fotossintese. 
DAVIS et alii (1976) estudando o efeito dos herbicidas prometrine, diuron, fluometuron e MSMA em Chlorella pyrenoidosa observaram que após 35 geraçōes, as concentraçōes mínimas para os herbicidas causarem um decréscimo nessa alga foram de $10^{-4} \mathrm{M}$ de diuron, $10^{-1} \mathrm{M}$ de prometrine e $10^{+} \mathrm{M}$ de fluometuron. O MSMA nāo teve nenhum efeito.

Quanto a fotossintese, os mesmos autores verificaram que ela foi inibida por uma exposição a luz de duas horas em concentraçōes de $5 \cdot 10^{-3} \mathrm{M}$ de prometrine ou diuron e de $5 \cdot 10^{t} \mathrm{M}$ de fluometuron.

A literatura apresenta efeitos de inibição de algas por herbicidas, particularmente nas doses altas dos produtos, entretanto, em baixas concentraçōes, como no caso do 2,4-D, verifica-se até um estímulo na síntese de clorofila. Contudo, verifica-se que as respostas apresentadas pelos organismos estudados, estāo ligadas à quantidade do herbicida aplicado, seu comportamento no solo e na planta e o mecanismo de ação. De maneira geral, nas doses normais de uso agrícola, os desequilibrios quando observados são pequenos e de curta duração.

\subsection{Efeito dos herbicidas na evoluçāo do $\mathrm{CO}_{2}$ do Solo}

A atividade microbiana do solo resulta da somatória da atividade das células individuais, que pode ser estimada através de mediçōes do metabolismo global do solo ou da quantificação por processos específicos. A descoberta de métodos alternativos indiretos para se estimar a biomassa e sua atividade, trouxe grandes evanços para a microbiologia do solo (SIQUEIRA \& FRANCO, 1988).

É importante lembrar, segundo GRISI (1984) que embora alguns aspectos permaneçam desconhecidos quando da avaliação da biomassa, tais como a taxa de crescimento e a contribuição relativa dos diferentes componentes vivos do solo, as mediçōes da atividade microbiana do solo fornecem dados úteis sobre o papel dos microrganismos na estrutura e função dos ecossistemas.

Dentre os métodos existentes, a taxa de respiração ou respiração edáfica, que é medida pela liberaçāo de $\mathrm{CO}_{2}$ ou consumo de $\mathrm{O}_{2}$ oriunda da atividade microbiana heterotrófica do solo, fornece informaçōes úteis sobre as transformaçōes das 
populaçōes microbianas, decorrentes de práticas agrícolas, como por exemplo, os efeitos de fertilizantes, defensivos em geral, manejo do solo e uso de biofertilizantes, assim como os efeitos dos diferentes sistemas de cultivo.

Por outro lado, sabe-se que as flutuaçōes naturais que ocorrem no solo da evoluçāo de $\mathrm{CO}_{2}$ e da absorçāo de $\mathrm{O}_{\varepsilon}$ são grandes, contudo esta variável é freqūentemente usada para a avaliaçāo da influência dos herbicidas sobre a atividade dos microrganismos do solo.

Segundo GROSSBARD (1976), as flutuaçōes naturais no solo da evoluçāo do $\mathrm{CO}_{2}$ e da absorção de $\mathrm{O}_{2}$ num determinado tempo sāo tāo pronunciadas, que um herbicida deverá exercer um efeito muito poderoso na microflora, para poder influenciar essa variabilidade natural no sistema. Porém, é mais provável que estes efeitos ocorram em altas doses. No entanto, diversos cientistas obtiveram resultados do efeito dos herbicidas na evoluçāo do $\mathrm{CO}_{8}$ e absorçāo de $\mathrm{O}_{\mathbf{8}}$ em doses normais de aplicaçāo.

Para ANDERSON (1978) desde que os herbicidas matem a vegetação, tratamentos com esses produtos resultam num aumento da matéria orgânica, tanto na superfície como no perfil do solo, e mudanças na respiraçāo do mesmo tém-se verificado.

É de conhecimento, que algumas moléculas de herbicidas, mesmo em baixas concentraçōes, podem inibir a atividade microbiana, entretanto, de maneira muito menos freqũente que nas altas. Os possíveis efeitos no caso das doses menores sāo transitórios e rápidos, sendo muitas vezes confundidos com as variaçōes naturais que ocorrem com a adiçāo de matéria orgânica no solo. Observa-se que as doses baixas podem trazer inibiçāo desde que repetidas a curtos periodos, nāo sendo este prazo suficiente para a degradaçāo dos herbicidas e/ou adaptaçāo dos microrganismos do solo à molécula aplicada (GROSSBARD \& DAVIES, 1976).

ANDERSON (1978) estudando o efeito do 2,4-D sobre a atividade respiratória da Escherichia coli, Aerobacter aerogenes e Micrococcus lysodeiktikun verificou inibiçāo para a concentraçāo de 2,21 ppm, enquanto que a Pseudomonas fluorescens, Staphylococcus aureus requereram 3,31 e 0,33 ppm, respectivamente. Concluindo que os herbicidas em geral nāo tem demonstrado efeito inibitório na atividade respiratória do solo, ou quando muito um leve efeito. 
Em pesquisa conduzida para determinar o efeito de vários herbicidas na respiraçāo de microrganismos contidos em três tipos de solos de Porto Rico, LIU \& CIBES-VIADÉ (1972) constataram um efeito inibitório significativo no oxigénio pela adiçāo de 2,4-D e trifluralina nos solos Coto e Fraternidade.

Entretanto, BARBOSA (1981) estudando os efeitos dos herbicidas fluometuron, simazine, atrazine, bromacil, bromacil+diuron (1:1), bromacil+diuron (2:1), terbacil, oxidiazon e nitrilodichlobenil, após 7 anos, concluiu que os mesmos nāo afetaram significativamente a respiraçāo do solo.

No entanto, a atrazine nas doses normais estimulou o crescimento e a respiraçāo dos microrganismos do solo, no período de 15-30 dias após a aplicaçāo na cultura do milho, enquanto o alachlor inibiu-os temporariamente. A fertilização com nitrato de amônio e superfosfato, acelerou a degradaçāo da atrazine e suprimiu os efeitos do herbicida nos microrganismos do solo (BAKALIVANOV \& LALOVA, 1979).

Finalizando, GROSSBARD (1976) revendo diversos trabalhos, comenta que ocorrem grandes divergências nos resultados obtidos para os mesmos herbicidas. Como exemplo, a simazine nāo afetou a evoluçāo de $\mathrm{CO}_{2}$ na concentraçāo de 8000 ppm em um trabalho, mas inibiu essa evoluçāo na concentraçāo de 5 ppm em outro trabalho, enfocando que essas diferenças devem ser devidas às diferenças de solo, principalmente. Ainda, nesta mesma revisāo o autor encontrou poucos herbicidas nāo causando efeitos nas doses elevadas e, que muitos herbicidas não causaram efeitos na respiraçāo do solo, até mesmo a estimulou quando aplicados em doses de campo. 


\section{MATERIAL E MÉTODOS}

\subsection{Local do Experimento e Características Edafo-climáticas}

O experimento de campo vinha sendo conduzido desde 1977, na Fazenda Sete

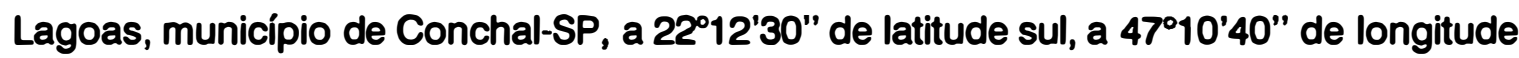
oeste de Greenwich (W.Gr.) e a 588m de altitude. O clima da regiāo é o Cwa, segundo a classificaçāo de Köeppen, ou seja, é clima mesotérmico de inverno seco, com temperatura média do mês mais quente superior a $22^{\circ} \mathrm{C}$, e a do mês mais frio inferior a $18^{\circ} \mathrm{C}$.

Os dados climáticos e o balanço hídrico mensal, segundo Thornthwaite e Mather (1955), citado por PESSOA (1985) sāo apresentados na Tabela 51 (apêndice), e o gráfico representativo do balanço hídrico na figura 3 (apêndice).

O solo foi classificado ao nivel de Grande Grupo, como Latossol Vermelho Amarelo (BRASIL, 1960), e segundo o SNLCS (Sistema Nacional de Levantamentos e Classificaçāo de Solo), como Latossol Vermelho Amarelo, Unidade Sāo Lucas (Quartzosamment Haplortox) com A moderado e textura média. O relevo do local é plano, e a declividade da área experimental é de 0,5\%. As características físicas e químicas do solo de acordo com análises realizadas em 1977 pelo Centro de Estudos de Solos da ESALQ-USP, e repetidas em 1990 pelo Laboratório de Química e Física do Solo do S.C.A.-UFPR, encontram-se na Tabela 1. 
Tabela 1 - Características químicas e físicas do solo Latossol Vermelho Amarelo Fazenda Sete Lagoas - Conchal-SP, 1977 e 1990.

\begin{tabular}{l|r|c}
\hline \multirow{2}{*}{ Determinaçōes } & \multicolumn{2}{c}{$\begin{array}{c}\text { Valores } \\
\text { Observados }\end{array}$} \\
\cline { 2 - 3 } & 1977 & 1990 \\
\hline \hline Acidez pH (água) & 4,90 & 4,80 \\
\hline Matéria Orgánica (\%) & 1,75 & 2,21 \\
\hline Fósforo Solúvel (PO'm.eq./100 ml de T.F.S.A.) & 0,04 & 0,05 \\
\hline Potássio Solúvel (K+m.eq./100 ml de T.F.S.A.) & 0,20 & 0,15 \\
\hline Cálcio (Ca ${ }^{++}$m.eq./100 ml de T.F.S.A.) & 1,07 & 1,90 \\
\hline Magnésio (Mg ${ }^{++}$m.eq./100 ml de T.F.S.A.) & 0,80 & 1,00 \\
\hline Alumínio trocável (Al+t+m.eq./100 ml de T.F.S.A.) & 0,56 & 0,20 \\
\hline Argila \% & 41,2 & 41,2 \\
\hline Limo \% & 16,0 & 16,0 \\
\hline Areia Fina \% & 30,5 & 30,5 \\
\hline Areia Grossa \% & 12,3 & 12,3 \\
\hline \hline
\end{tabular}

\subsection{Cultivar}

Foram utilizadas plantas do cultivar Pera Citrus sinensis (L.) Osbeck, enxertados sobre limão 'Cravo' Citrus limonia Osbeck, plantadas em maio de 1975. 


\subsection{Herbicidas utilizados"}

Dos herbicidas utilizados no presente trabalho, as principais características aqui relatadas, estāo baseadas nos livros Guia de Herbicidas 2 ed. (1988) e Herbicide Handboock, da Weed Science Society of America (1989), assim como nos boletins técnicos das companhias produtoras.

\subsubsection{Terbacil}

Formulaçāo comercial utilizada: Simbar"*

Ingrediente ativo: 3-tert-butil-5-cloro-6-metiluracil.

Classe toxicológica: formulaçao $800 \mathrm{~g} / \mathrm{Kg}$ - classe III - pouco tóxico (faixa azul)

Características principais: foi utilizada a formulação pó-molhável contendo $80 \%$ do ingrediente ativo (terbacil). A solubilidade em água é de $710 \mathrm{ppm}$ a $25^{\circ} \mathrm{C}$. e a pressāo de vapor a $29,5^{\circ} \mathrm{C}$ é de $4,7 \times 10^{-7} \mathrm{~mm}$ de $\mathrm{Hg}$. É um herbicida de translocação predominantemente apoplástica, pertencente ao grupo dos inibidores de fotossíntese, controlando plantas daninhas monocotiledôneas e dicotiledôneas anuais, e algumas perenes. É recomendado para aplicaçāo em pré ou em pós-emergência do mato. $\mathrm{Na}$ planta é metabolizado a 3-tert-butil-5-cloro-hidroximetiluracil e, em seguida conjugado para formar um $\beta$-glucosídeo muito persistente; quando em alfa, encontrou-se $12 \%$ do terbacil e seus metabolitos 6 a 8 meses após a aplicação. Apresenta-se moderadamente adsorvido pelos colóides do solo; lixiviável, principalmente em solos arenosos. O principal mecanismo de degradação é o microbiano e secundariamente por reaçōes químicas com os ácidos orgânicos da soluçāo do solo.

'As citaçōes de nomes ou marcas comerciais de herbicidas ou quaisquer outros produtos neste trabalho, nāo implicam em quaisquer preferências, mas apenas e unicamente na propriedade de conterem os ingredientes ativos aqui testados.

"Produto comercial da Du Pont do Brasil S.A. 
É resistente à fotodecomposição; as perdas por volatilizaçāo são despreziveis. Sua persistência média no solo às doses recomendadas é de meia-vida de 5 a 6 meses; a DLso oral aguda, para ratos, é de 5000 a 7500 mg (i.a.)/kg de peso vivo.

\subsubsection{Simazine}

Formulação comercial utilizada: Gesatop

Ingrediente ativo: 2-cloro-4,6-bis (etilamino)-s-triazina.

Classe toxicológica: formulaçōes $800 \mathrm{~g} / \mathrm{Kg}$ - classe III - pouco tóxico (faixa azul)

Características principais: as formulaçōes comerciais utilizadas foram a pómolhável com $80 \%$ de ingrediente ativo (simazine) ou a suspensāo concentrada (flowable) contendo $50 \%$ do ingrediente ativo. A solubilidade em água do simazine é $5 \mathrm{ppm}$ a $20^{\circ} \mathrm{C}$ e a pressão de vapor a $20^{\circ} \mathrm{C}$ é $6,1 \times 10^{-9} \mathrm{~mm}$ de $\mathrm{Hg}$. É um herbicida de translocaçāo predominantemente apoplástica, com pouca ação foliar, controlando plantas daninhas monocotiledôneas e dicotiledôneas através da inibiçāo da fotossíntese. É recomendado para aplicação em pré-emergência do mato. Seu metabolismo nas plantas tolerantes, numa primeira etapa é degradado enzimaticamente a hidroxisimazine e aminoácidos conjugados, posteriormente metabolizado também por reaçōes enzimáticas de dealquilaçāo e hidrólise. É adsonido em solos com alto teor de argila e/ou matéria orgânica, e por essa razāo e também pela sua baixa solubilidade apresenta lixiviação limitada, mantendo-se nos solos agrícolas, em geral, nos primeiros $5 \mathrm{~cm}$ superficiais. A degradação no solo é essencialmente microbiana, por via química ocorre hidrólise com formação de hidroxisimazine e dealquilação dos grupos aminos, pressupondo em seguida ruptura do anel. As perdas por fotodecomposição e volatilização são consideradas insignificantes, com persistência média no solo às dose recomendadas de 5 a 7 meses, dependendo do solo e do clima. A sua $D_{\text {so }}$ oral aguda, para ratos, é 5000 (i.a.) $\mathrm{mg} / \mathrm{kg}$ de peso vivo.

'Produto Comercial da Ciba-Geigy Química S.A. 


\subsubsection{Dichlobenil}

Formulação comercial utilizada: Casoron ${ }^{*}$

Ingrediente ativo: 2,6-diclorobenzonitrila

Classe toxicológica: formulação $67,5 \mathrm{~g} / \mathrm{Kg}$ - classe III - pouco tóxico (faixa azul).

Características principais: foram utilizadas formulaçōes granuladas contendo $7,5 \%$ e $5 \%$ do ingrediente ativo (dichlobenil). A solubilidade em água é de 18 ppm a $20^{\circ} \mathrm{C}$, e a pressão de vapor a $20^{\circ} \mathrm{C}$ é $5,5 \times 10^{-4} \mathrm{~mm}$ de $\mathrm{Hg}$. É um herbicida de translocaçāo predominante apoplástica, controlando plantas daninhas monocotiledôneas e dicotiledôneas, sendo um inibidor de divisão celular, atuando nas regiōes de crescimento. Normalmente é recomendado para aplicação em préemergência, e quando incorporado, tem apresentado melhores resultados devido à volatilidade que apresenta. O mecanismo de degradação na planta é enzimático, ocorrendo a hidroxilaçāo no núcleo benzeno, predominantemente na posição 3 e, em menor intensidade na posição 4, seguida de conjugação.

É fortemente adsorvido pelos colóides orgânicos e em menor intensidade pelos colóides de argila, o deslocamento vertical na água do solo é extremamente baixo, ocorrendo transporte, por difusāo, na fase gasosa. A degradaçāo no solo se dá pelos microrganismos, o dichlobenilé decomposto a 2,6-diclorobenzamida (BAM), que possui açāo herbicida. As perdas por fotodecomposiçāo e volatilizaçāo são muito intensa, a molécula é muito volátil, principalmente quando se encontra sobre solo úmido, sujeito a altas temperaturas e baixa umidade relativa. A persistência média no solo às doses recomendadas é de 2 a 6 meses, dependendo da dose aplicada, teor de matéria orgânica do solo e condiçōes climáticas. A DL $L_{s o}$ oral aguda, para ratos, é de $3160 \mathrm{mg}$ (i.a.)/kg de peso vivo.

'Produto Comercial da Iharabrás S.A. Indústrias Químicas. 


\subsubsection{Diuron}

Formulaçāo comercial utilizada: Karmex"

Ingrediente ativo: 3-(3,4-diclorofenil)-1,1-dimetiluréia.

Classe toxicológica: formulação $500 \mathrm{~g} /$ e $600 \mathrm{~g} /$ - classe II - medianamente tóxico (faixa amarela); formulação $800 \mathrm{~g} / \mathrm{Kg}$ - classe III - pouco tóxico (faixa azul).

Características principais: foi utilizada a formulação pó-molhável contendo $80 \%$ do ingrediente ativo (diuron). A solubilidade em água é de $42 \mathrm{ppm}$ a $25^{\circ} \mathrm{C}$, e a pressão de vapor a $50^{\circ} \mathrm{C}$ é de $0,31 \times 10^{-5} \mathrm{~mm}$ de $\mathrm{Hg}$. É um herbicida de translocação predominantemente apoplástica, pertencente ao grupo dos inibidores de fotossíntese, controlando plantas daninhas dicotiledôneas e monocotiledôneas anuais. É recomendado para aplicação em pré-emergência, ou em pós-emergência com a adição de um surfatante à calda. O metabolismo de destoxificação nas espécies resistentes envolve demetilação e hidroxilação da molécula. O diuron é adsorvido pelos colóides de argila e matéria orgánica do solo, sendo pouco lixiviável em solos argilosos mas lixiviável nos arenosos. A principal via de degradação da molécula no solo é a microbiana. As perdas por fotodecomposiçāo e volatilizaçāo sāo moderadas, quando exposto na superfície do terreno por vários dias, sob condiçōes de temperatura alta e baixa umidade. Apresenta persistência média no solo às doses recomendadas de 4 a 8 meses, dependendo do tipo de solo e das condições climáticas. $A$ DL $_{s o}$ oral aguda, para ratos, é $3400 \mathrm{mg}$ (i.a.)/kg de peso vivo.

\subsubsection{Bromacil}

Formulação comercial utilizada: Hyvar $X *$

Ingrediente ativo: 5-bromo-3 sec-butil-6-metiluracil.

Classe toxicológica: formulação $800 \mathrm{~g} / \mathrm{Kg}$ - classe III - pouco tóxico (faixa azul).

\footnotetext{
'Produto Comercial da Du Pont do Brasil S.A.

“Produto Comercial da Du Pont do Brasil S.A.
} 
Características principais: foi utilizada a formulação pó-molhável contendo $80 \%$ do ingrediente ativo (bromacil). A solubilidade em água é de $815 \mathrm{ppm}$ a $25^{\circ} \mathrm{C}$. É um herbicida de translocação predominantemente apoplástica, controlando plantas daninhas monocotiledóneas e dicotiledóneas, assim como algumas plantas arbustivas, sendo um potente inibidor fotossintético. É recomendado para aplicaçáo em préemergência, podendo ser utilizada em pós-emergência com a adição à calda de um sulfatante. É metabolizado a 5-bromo-3-sec-butil-6-hidroximetiluracil pelas plantas tolerantes como forma de destoxificação. A adsorção da molécula no solo se dá pelos colóides de argila e matéria orgânica, apresentando nessas condiçōes moderada lixiviaçāo. A degradaçāo do bromacil no solo é essencialmente microbiana, sendo favorecida em condiçōes de solo úmido e quente. As perdas por fotodecomposição e volatilizaçāo sāo consideradas insignificantes. Sua persistência média no solo às doses recomendadas com meia-vida de 5 a 6 meses para culturas recomendadas e superior a 1 ano em áreas industriais. A DL $L_{s o}$ oral aguda, para ratos, é de $5200 \mathrm{mg}$ (i.a.)/kg de peso vivo.

\subsubsection{Bromacil + Diuron}

Formulação comercial utilizada: Krovar I e Krovar II"

Ingrediente ativo: descritos nos ítens 3.3.4 e 3.3.5.

Classe toxicológica: formulação $400+400 \mathrm{~g} / \mathrm{Kg}$ - classe III - pouco tóxico (faixa azul).

Características principais: descritos os ítens 3.3.4 e 3.3.5. Com alteração na toxicologia, que para a formulação Bromacil + Diuron a $400+400 \mathrm{~g}$.i.a/kg apresentou $\mathrm{DL}_{\text {so }}$ oral aguda, para ratos, igual a $5980 \mathrm{mg}$ (i.a.)/kg de peso vivo.

Foram utilizada as formulaçōes comerciais pós-molháveis, contendo $80 \%$ do ingrediente ativo (bromacil + diuron). A formulação comercial Krovar I contém $40 \%$ de bromacil e $40 \%$ de diuron, e a Krovar II contém $53,3 \%$ de bromacil e $26,7 \%$ de diuron.

"Produto Comercial da Du Pont do Brasil S.A. 


\subsection{Delineamento experimental}

O delineamento experimental adotado para o experimento de campo, foi o de blocos casualizado, com 8 tratamentos e 3 repetiçóes. As unidades experimentais constituiram-se de 4 plantas espaçadas de $4,5 \mathrm{~m}$, e o tamanho de cada parcela de 3,0 $\times 18,0 \mathrm{~m}$, com uma área total de $54 \mathrm{~m}^{2}$.

Os tratamentos utilizados com as respectivas doses do ingrediente ativo (i.a.) e do produto comercial (p.c.), encontram-se na tabela 2.

Tabela 2- Tratamentos utilizados com as respectivas doses dos ingredientes ativos (i.a.) e dos produtos comerciais (p.c.) Fazenda Sete Lagoas- ConchalSP, 1990.

\begin{tabular}{|c|c|c|c|}
\hline \multirow[b]{2}{*}{ TRATAMENTOS } & \multirow{2}{*}{ PRODUTO COMERCIAL } & \multicolumn{2}{|c|}{ DOSES - Kg/ha } \\
\hline & & i.a. & p.c. \\
\hline 1. Testemunha" & - & -...... & - -ב-ב-ב \\
\hline 2. Testumunha Capinada“ & - & ----- & -.---- \\
\hline 3. Terbacil & Simbar & 3,2 & 4,0 \\
\hline 4. Simazine & Gesatop & 4,0 & 5,0 \\
\hline 5. Dichlobenil & Casoron & 5,0 & 100,0 \\
\hline 6. Diuron & Karmex & 3,2 & 4,0 \\
\hline 7. Bromacil & Hyvar X & 3,2 & 4,0 \\
\hline 8. Bromacil + Diuron & Krovar II & 3,2 & 4,0 \\
\hline
\end{tabular}

- testemunha recebia uma capina anual por ocasião da aplicação dos herbicidas.

** era sempre capinada por ocasiāo da aplicação dos herbicidas e quando atingia $25 \%$ da cobertura pelas plantas daninhas. 


\subsection{Instalação e condução dos experimentos de campo e laboratório}

\subsubsection{Aplicação dos herbicidas}

As aplicaçōes foram realizadas anualmente, tendo seu início em outubro de 1977, através de pulverizador Jacto manual, com capacidade de 20 litros, e munido de uma barra de aplicação contendo três bicos Teejet 80.02. Inicialmente, antes de cada aplicação todas as parcelas foram capinadas homogeneamente e, retirado do local da capina todo e qualquer resíduo vegetal, ficando o solo totalmente nu. As aplicaçōes foram realizadas com um consumo de calda de $300 \mathrm{l} / \mathrm{ha}$. A partir do ano de 1980, devido à dificuldade de aplicação com barra, as aplicaçōes passaram a ser realizadas com apenas 1 bico polijet azul, também com um consumo de calda de $300 \mathrm{l} / \mathrm{ha}$. As aplicaçōes eram realizadas em faixa de $1,5 \mathrm{~m}$ de cada lado da planta, ressaltando que a mesma sempre foi realizada inclusive sob a copa das plantas.

\subsubsection{Coletas de amostras}

As amostragens de solo e raíz para estudo de laboratório, foram realizadas nas unidades experimentais com o seguinte procedimento: o solo foi amostrado utilizandose trado de caneca com $9 \mathrm{~cm}$ de diametro por $14 \mathrm{~cm}$ de altura, fazendo-se 2 furos um de cada lado da planta num total de 8 furos por unidade experimental, na profundidade de $0-10 \mathrm{~cm}$. As mesmas foram acondicionadas em sacos plásticos e transportadas em caixas de isopor fechadas até o laboratório. No mesmo local onde se fez os furos para as amostragens do solo, com o auxílio de um enxadāo coletou-se o sistema radicial das plantas de citros assegurando desta forma que as raízes a serem estudadas fossem realmente as dos citros, e não fossem confundidas com raízes de outras plantas do local. As raízes coletadas, foram acondicionadas em sacos plásticos e também conduzidas ao laboratório em caixas de isopor fechadas:

Este procedimento foi adotado para todas as épocas coletadas de acordo com as variáveis deste estudo conforme a Tabela 3. 
Tabela 3 - Épocas amostradas, material coletado e respectivas variáveis estudadas Fazenda Sete Lagoas - Conchal- SP,1990.

\begin{tabular}{|c|c|c|}
\hline $\begin{array}{l}\text { ÉPOCA DE } \\
\text { AMOSTRAGEM }\end{array}$ & $\begin{array}{l}\text { MATERIAL } \\
\text { COLETADO }\end{array}$ & VARIÁVEIS ESTUDADAS \\
\hline $\begin{array}{l}\text { Antes da aplicação anual } \\
\text { dos tratamentos } \\
(16 / 01 / 1990)\end{array}$ & $\begin{array}{l}\text { solo } \\
\text { raiz }\end{array}$ & $\begin{array}{l}\text { - Atividade da microflora heterotrófica } \\
\text { do solo } \\
\text { - População de esporos MVA } \\
\text { - Colonizaçāo por fungos MVA } \\
\text { - Teor de fósforo disponivel }\end{array}$ \\
\hline $\begin{array}{l}\text { Dois dias após a aplicação } \\
\text { anual dos tratamentos } \\
(18 / 01 / 1990)\end{array}$ & solo & $\begin{array}{l}\text { - Atividade da microflora heterotrófica } \\
\text { do solo }\end{array}$ \\
\hline $\begin{array}{l}\text { Trinta dias após a } \\
\text { aplicaçāo anual dos } \\
\text { tratamentos }(15 / 02 / 1990)\end{array}$ & solo & $\begin{array}{l}\text { - Atividade da microflora heterotrófica } \\
\text { do solo }\end{array}$ \\
\hline $\begin{array}{l}\text { Sessenta dias após a } \\
\text { aplicação anual dos } \\
\text { tratamentos }(20 / 03 / 1990)\end{array}$ & solo raiz & $\begin{array}{l}\text { - Atividade da microflora heterotrófica } \\
\text { do solo } \\
\text { - População de esporos MVA } \\
\text { - Colonizaçāo por fungos MVA } \\
\text { - Teor de fósforo disponivel }\end{array}$ \\
\hline $\begin{array}{l}\text { Cento e vinte dias após a } \\
\text { aplicação anual dos } \\
\text { tratamentos }(22 / 05 / 1990)\end{array}$ & solo raiz & $\begin{array}{l}\text { - Atividade da microflora heterotrófica } \\
\text { do solo } \\
\text { - Populaçāo de esporos MVA } \\
\text { - Colonizaçāo por fungos MVA }\end{array}$ \\
\hline
\end{tabular}

\subsubsection{Preparo das amostras}

O solo procedente dos 8 furos de cada unidade experimental, foi homogeneizado e quarteado fazendo-se amostra composta, da qual se retirou material para os respectivos estudos, conforme tabela 3. Da mesma forma, as amostras de raízes foram reunidas em amostras compostas, para cada unidade experimental, foram lavadas e acondicionadas em frascos contendo F.A.A. (formol, ácido acético e etanol $50 \%$ na relação de 2,6:1:40), para preserválas até o momento oportuno para a avaliação da colonização por fungos MVA. 


\subsection{Metodologia Analítica}

3.6.1. Atividade da microflora heterotrófica do solo

Para analisar o efeito dos diferentes herbicidas na atividade da microflora heterotrófica do solo, foi utilizado o método radiorespirométrico, utilizando como substrato a glicose marcada com ${ }^{14} \mathrm{C}$ (FREITAS et alii, 1979).

Após a coleta das amostras no campo, 1,0g de solo fresco foi separado, em triplicata para cada tratamento, e distribuídos em erlenmeyers de $75 \mathrm{ml}$. Sobre este solo foi adicionado $0,5 \mathrm{ml}$ de uma solução de glicose $-{ }^{14} \mathrm{C} 2 \mu \mathrm{mol} / \mathrm{ml}$ com atividade de 0,05 $\mu \mathrm{Ci} / \mathrm{ml}$. Posteriormente, os frascos foram fechados e deixados à temperatura ambiente. No interior dos erlenmeyers, foram colocados cubetas contendo $0,25 \mathrm{ml}$ de feniletilamina, para absorver $0 \mathrm{CO}_{2}$ resultante da metabolizaçāo da glicose radiomarcada, e para aumentar a superfície de contato entre $\mathrm{O} \mathrm{CO}_{2}$ e a feniletilamina utilizou-se de pequenas tiras de papel de filtro, de igual tamanho (Figura 1).

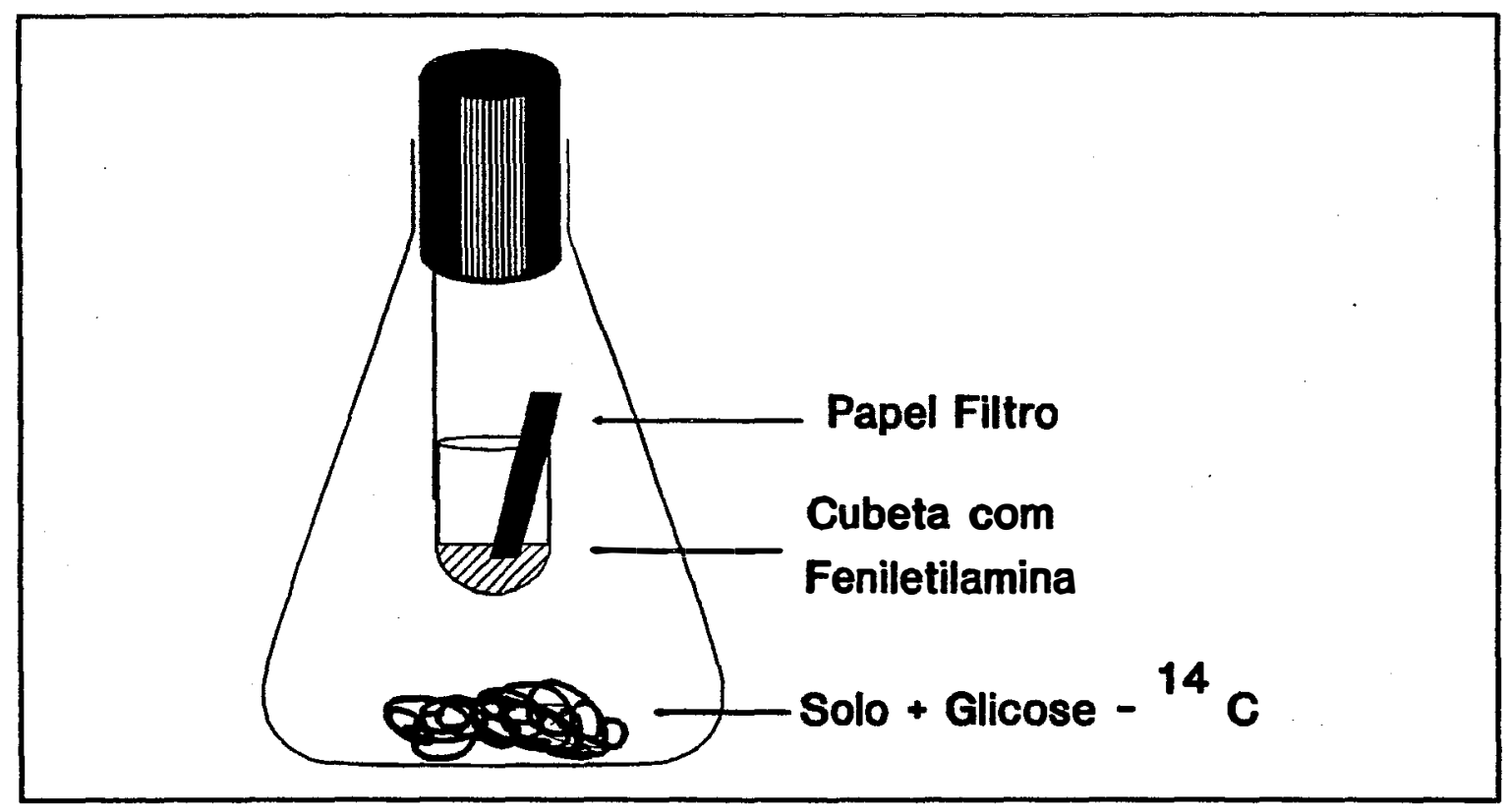

Figura 1 - Frasco Rádiorespirométrico

Após 1,0 hora de incubação, a reação foi paralisada pela adição de $2 \mathrm{ml}$ de HCL IN sobre o solo, e, o papel de filtro juntamente com a feniletilamina foram transferidos para frascos de cintilaçāo contendo $15 \mathrm{ml}$ de soluçāo cintiladora (PATTERSON \& 
GREENE, 1965). Como padrāo, $0,5 \mathrm{ml}$ da soluçāo de glicose - ${ }^{14} \mathrm{C}$, também, foi transferida para frascos de cintilaçāo, e as contagens do ${ }^{14} \mathrm{C}$ das amostras, como da glicose do padrāo, foram realizadas em um cintilador líquido BECKMAN L5-230, pertencente à Seção de Radioisótopos do CENA.

A quantidade de glicose consumida pelos microrganismos do solo, é proporcional à contagem por minuto (cpm), dado pelo cintilador líquido, através da leitura do isótopo radioativo ( $\left.{ }^{4 a} \mathrm{C}\right)$. Essa quantidade de glicose consumida, expressa em $\mu \mathrm{mol}$ de glicose/g solo x hora, foi obtida pela seguinte equação:

$$
X=\frac{a}{a_{0}} \times \frac{C}{M} \times \frac{V}{T}
$$

onde,

$X=$ quantidade de glicose consumida $g^{-1} \cdot h^{-1}$;

$a=$ contagem por minuto da amostra;

$a_{0}=$ contagem por minuto do padrāo;

$\mathrm{C}=$ concentraçāo da soluçāo de glicose $-{ }^{14} \mathrm{C}(\mu \mathrm{mol} / \mathrm{ml})$

$M=$ massa de solo (g);

$V=$ volume de solução glicose $-{ }^{14} \mathrm{C}(\mathrm{ml})$ adicionada ao solo e

$T=$ tempo de incubaçāo das amostras (hora).

\subsubsection{Colonização micorrízica MVA}

A colonizaçāo micorrizica foi avaliada, utilizando-se de partes de raízes preservadas em F.A.A. O clareamento e coloraçāo foram feitos seguindo-se a técnica de PHILLIPS \& HAYMAN (1970), em que consiste colocar 0,5g de raíz em um frasco contendo $20 \mathrm{ml}$ de uma soluçāo de $\mathrm{KOH} 10 \%$ e aquecé-lo a $90^{\circ} \mathrm{C}$ em banho-maria por 60 minutos. Em seguida o material foi lavado com água corrente em abundância e colocado em $\mathrm{H}_{2} \mathrm{O}_{2} 10$ volumes (preparando na hora do uso) por 60 minutos a frio. 
Após o material foi novamente lavado com água corrente em abundância e mergulhado em HCl 2\% por 3 minutos. Procedeu-se então a coloração das amostras, colocando-as em uma solução de $20 \mathrm{ml}$ com "typan blue" em lactoglicerol 0,05\% e aquecida por 5 minutos a $90^{\circ} \mathrm{C}$.

Posteriormente, preparou-se as lâminas para avaliação em microscopia óptica $400 x$, da porcentagem de colonizaçāo de acordo com BIERMANN \& LINDERMAN (1981), tomando-se ao acaso, 10 (dez) segmentos de raízes coradas com comprimento de $1 \mathrm{~cm}$ e colocadas sobre lâminas com uma gota de lactoglicerol incolor e recobertas com lamínulas.

A avaliaçāo foi subjetiva e visual, e foi realizada observando-se cada segmento sob microcospia óptica com aumento de $400 \times$ atribuindo-se notas de 0 a 100 (onde a nota 0 (zero) representava ausência de colonização e a nota 100 (cem) representava que o segmento radicular estava totalmente colonizado) para a colonização em cada segmento. Após atribuida as notas de porcentagens de colonização para cada segmento, somou-se as notas dos 10 segmentos e extraiu-se a média aritimética, constituindo-se esta média a nota de colonização para aquela lâmina.

\subsubsection{Quantificação da população de esporos MVA.}

A separação dos esporos de fungos MVA do solo, foi feita através do peneiramento úmido e decantaçāo segundo GERDEMANN \& NICOLSON (1963). Alíquotas de $50 \mathrm{ml}$ de solo foram suspendidas em $1000 \mathrm{ml}$ de água através de uma agitaçāo vigorosa, para que um maior número de partículas ficassem em suspensāo. A solução foi então passada por um conjunto de peneiras com malhas de abertura entre 250 a 50 micra. Esse processo foi repetido por duas vezes. Em seguida, foi realizada a centrifugação $(2500 \mathrm{~g})$ do material retido na peneira de $\mathbf{5 0}$ micra de abertura de malha, após suspensāo em solução de sacarose 40\% (OHMS, 1957), para que fossem eliminadas as particulas mais densas que os esporos. A quantificação dos esporos foi realizada em placa nematológica com anéis concêntricos, utilizando-se de microscopia óptica com aumentos de 40 a $120 \mathrm{x}$. 


\subsubsection{Teores de Fósforo.}

Analisadas pelo Laboratório de Química do Solo do Departamento de Solo do Setor de Ciências Agrárias da Universidade Federal do Paraná, sendo o fósforo determinado colorimetricamente utilizando reagente de molibdato de amónio (EMBRAPA, 1979).

\subsection{Metodologia Estatística}

As observaçōes sucessivas foram realizadas numa mesma parcela, em períodos diferentes. Para a variável atividade da microflora heterotrófica do solo foram feitas observaçōes em 5 períodos, para as variáveis populaçāo de esporos MVA e colonizaçāo por fungos MVA em 3 períodos e para a variável teores de fósforo disponivel em 2 períodos. Os níveis desta causa de variação (o tempo) foram considerados como tratamentos secundários. Nas diferentes parcelas foram aplicados os 8 tratamentos principais descritos, e foram realizadas 3 repetições.

Desta forma ficou caracterizado um delineamento em parcelas subdivididas no tempo, onde as parcelas são os 8 tratamentos principais e as subparcelas os diferentes períodos.

O quadro da Análise de Variância para o esquema exposto é o que segue:

\begin{tabular}{lcc}
\hline \hline CAUSAS DA VARIAÇÃO & GRAUS DE LIBERDADE & QUADRADOS MÉDIOS \\
\hline \hline Blocos & 2 & QMTr \\
Tratamentos (Tr) & 7 & QMR (a) \\
Resíduo (a) & 14 & \\
\hline (Parcelas) & 23 & QMTe \\
\hline Tempo (Te) & $t-1$ & QMTr x Te \\
Interação Tr x Te & $7(t-1)$ & QMR (b) \\
Resíduo (b) & $16(t-1)$ & \\
\hline Subparcelas & $n-1$ & \\
\hline \hline
\end{tabular}


$t=0$ número de períodos $(5,3,3$ e 2$)$ para as variáveis atividade da microflora heterotrófica do solo, populaçāo de esporos MVA, colonizaçāo por fungos MVA e teores de fósforo disponivel;

$\mathrm{n}=0$ número total de observaçōes para cada uma das variáveis, respectivamente 120, 72, 72 e 48 .

A significância estatística das diferenças entre as respostas nos tratamentos, nos diferentes tempos e nas interaçōes entre tratamentos e tempos foi analisada através do teste $F$ (a razāo entre os quadrados médios dos fatores e os respectivos quadrados médios residuais. Esta significância é dada pela probabilidade "p" - o nível de significância do teste).

As hipótese formuladas sāo as que se seguem:

Para a variável atividade microflora heterotrófica do solo:

P/ os tratamentos: Ho: TR1 $=$ TR2 $=\ldots$ TR8

H1: Pelo menos um trat. é diferente dos outros.

P/ os tempos: $\quad$ Ho: $\mathrm{TE} 1=\mathrm{TE2}=\ldots$ TE5

H1: Existe pelo menos um tempo diferente.

P/ as interaçōes: Ho: TR1xTE1 $=$ TR1xTE2 $=$...TR1xTE5 $=.$. TR8xTE5

H1: Pelo menos uma interação é diferente.

Para as variáveis percentual de colonizaçāo e número de esporos

P/ tratamentos: $\quad$ Ho: TR1 $=$ TR2 $=\ldots$ TR8

H1: Pelo menos um trat. é diferente dos outros.

P/ tempos: $\quad$ Ho: TE1 $=$ TE2 $=$ TE3

H1: Existe pelo menos um tempo diferente.

P/ interaçōes: $\quad$ Ho: TR1xTE1 $=$ TR1xTE2 $=$ TR1xTE3 $=.$. TR8xTE3

H1: Ao menos uma interaçāo difere.

Para a variável teor de fósforo

P/ tratamentos: Ho: TR1 $=\mathrm{TR} 2=\ldots=\mathrm{TR} 8$

H1: Pelo menos um trat. é diferente dos outros.

P/ tempos: $\quad$ Ho: TE1 = TE2

H1: Existe pelo menos um tempo diferente.

P/ interaçōes: $\quad$ Ho: TR1xTE1 $=$ TR1xTE2 $=\ldots=$ TR8xTE2 
H1: Ao menos uma interaçāo difere.

As hipótese para efeitos principais, secundários e das interaçōes foram testadas através da análise de variância. Nos casos em que os testes eram estatisticamente significativos foi realizado o teste de comparaçōes múltiplas (teste de TUKEY) para localizar as diferenças. No caso de interaçōes significativas foram realizados testes de comparaçōes de efeitos principais e secundários dentro de cada nível dos efeitos secundários e principais respectivamente.

Todas as observaçōes da terceira repetiçāo do oitavo tratamento foram perdidas. Para a consecuçāo da análise, elas foram estimadas de maneira a tornar mínima a Soma de Quadrados dos Resíduos (PIMENTEL GOMES, 1987).

Os valores estimados foram substituidos pelos valores perdidos e a análise foi feita como a anterior, com um grau de liberdade a menos para os Resíduos. 0 quadrado médio relativo ao residuo está corretamente estimado, e o correspondente a tratamentos está ligeiramente maior. Tanto a correção dos graus de liberdade do resíduo como a correçāo da soma de quadrados dos tratamentos conduziram aos mesmos resultados obtidos sem estas correçōes. Ainda, testou-se a necessidade de transformaçāo dos dados para todas as variáveis estudadas, mostrando não ser necessário. Os autores consultados para a análise desse estudo foram SNEDECOR \& COCHRAN (1967); MEAD \& CURNOW (1983) e PIMENTEL GOMES (1987). 


\section{RESULTADOS E DISCUSSĀO}

\subsection{Teores de fósforo}

Para o estudo da influência dos herbicidas na micorrização simbiótica um fator importante que deve ser considerado, trata-se da disponibilidade de nutrientes no solo.

A micorrizaçāo é geralmente inibida em condiçōes de elevada fertilidade, sendo verificado por diversos autores que nessas condiçōes a ocorrência e intensidade da simbiose MVA são significativamente menores, como observado nos trabalhos de JENSEN \& JAKOBSEN, 1980; MOSS et alii, 1981 e SIQUEIRA \& FRANCO, 1988).

Dentre os nutrientes essenciais que compóem a fertilidade do solo, inúmeros trabalhos têm mostrado a importância do fósforo no processo da micorrização, concordando que altos níveis de fósforo no solo diminuem a colonizaçāo micorrizica MVA, bem como a resposta do hospedeiro à simbiose (GERDERMANN, 1968; MOSSE, 1973; TINKER, 1975; COOPER, 1975; SMITH, 1978; KUCEY \& PAUL, 1983; SIQUEIRA \& FRANCO, 1988 e CARDOSO, 1990).

A importância que assume esse elemento, em especial, no processo de micorrizaçāo, inicialmente estudou-se a homogeneidade dos teores de fósforo dos diferentes tratamentos para se assegurar que os efeitos observados na colonização das raizes dos citros e esporulaçāo sejam devidos aos tratamentos e nāo ao efeito desse nutriente. Os dados originais dos teores de fósforo, encontram-se na Tabela 4. 
Tabela 4 - Teores de fósforo, em ppm, encontrados nos diferentes tratamentos para os tempos (1) e (2) - Fazenda Sete Lagoas - Conchal - SP, 1990.

$\begin{array}{llr} & 7 & 5 \\ \text { 1. Testemunha } & 8 & 13\end{array}$

$20 \quad 20$

2. Testemunha capinada

3. Terbacil

4. Simazine

5. Dichlobenil

26

6. Diuron

20

19

19

7

17

26

16

7. Bromacil

11

26

8

12

17

8. Bromacil + Diuron

28

16

17

Processados os dados estatisticamente, a análise de variância mostrou que não houve diferentes respostas nos teores de fósforo para os diferentes tratamentos. 0 mesmo se verificou para os tempos estabelecidos e as interaçōes entre tempo e tratamento, como mostra a Tabela 5. 
Tabela 5 - Quadro da análise de variância para os teores de fósforo, média geral e coeficientes de variaçāo.

\begin{tabular}{lrrrrr}
\hline $\begin{array}{c}\text { Causas da } \\
\text { Variação }\end{array}$ & G.L. & S.Q. & Q.M. & $\begin{array}{c}\text { VALOR } \\
\text { F }\end{array}$ & PROB.>F \\
\hline BLOCO & 2 & 135,7916667 & & & \\
TRATAMENTO & 7 & 260,1458333 & 37,1636905 & 0,8278 & 0,58178 \\
RESIDUO (A) & 14 & 628,5416667 & 44,8958333 & & \\
\hline
\end{tabular}

$\begin{array}{lrrrrr}\text { PARCELAS } & 23 & 1024,4791667 & & & \\ \text { TEMPO } & 1 & 15,1875000 & 15,1875000 & 0,3558 & 0,56538 \\ \text { TRAXTEM } & 7 & 186,3125000 & 26,6160714 & 0,6235 & 0,73081 \\ \text { RESIDUO (B) } & 16 & 683,0000000 & 42,6875000 & & \end{array}$

\begin{tabular}{lll}
\hline TOTAL & $47 \quad 1908,9791667$ \\
\hline
\end{tabular}

MÉDIA GERAL $=16,020834$

COEFICIENTE DE VARIAÇĀO $(A)=29,574 \%$

COEFICIENTE DE VARIAÇĀO $(B)=40,782 \%$

Esses resultados foram entāo interprtados segundo a ROLAS (Rede Oficial de Laboratórios de Análises de Solos), que considera teor alto para esse nutriente, valor maior que 12 ppm segundo as características físicas do solo estudado. Encontrando-se para os diferentes tratamentos nas duas avaliaçōes valor médio de 16.02 ppm (Tabela 5). 


\subsection{Colonização micorrízica MVA}

Os efeitos benéficos da simbiose MVA, a capacidade das mesmas em aumentar o crescimento e a sobrevivência das plantas com significativos ganhos na produçāo, em razão de condiçōes ambientais adversas, têm sido amplamente documentados (KLEINSCHIMIDT \& GERDERMANN, 1972; SCHENK \& TUCKER, 1974; MENGE et alii, 1975, 1977 e 1978; TIMMER \& LEYDEN, 1979; HAYMANN, 1982; MENGE, 1983; GRAHAM \& TIMMER, 1984; CARDOSO et alii, 1986; FONTANEZZI et alii, 1987; ANTUNES \& CARDOSO, 1987; SIQUEIRA \& FRANCO, 1988 entre outros).

Dada a importância que assumem esses fungos micorrizicos em determinados processos produtivos, torna-se necessário identificar dentro de um sistema de produçāo agrícola, onde a contribuiçāo da simbiose MVA é relevante. Como por exemplo em citros, deve-se estudar 0 efeito detrimental dos diferentes manejos culturais $e$ fitossanitários (GREAVES \& MALKOMES, 1980).

Os efeitos dos tratamentos herbicidas na colonizaçāo micorrizica MVA encontrase na Tabela 6.

Tabela 6 - Percentagem de colonização micorrízica VA, por 10 seguimentos de raízes coradas com comprimento de $1 \mathrm{~cm}$, colocados sobre lâminas, atribuindo-se notas de 0 (zero) a 100 (cem) ${ }^{*}$ - Fazenda Sete Lagoas - Conchal - SP, 1990.

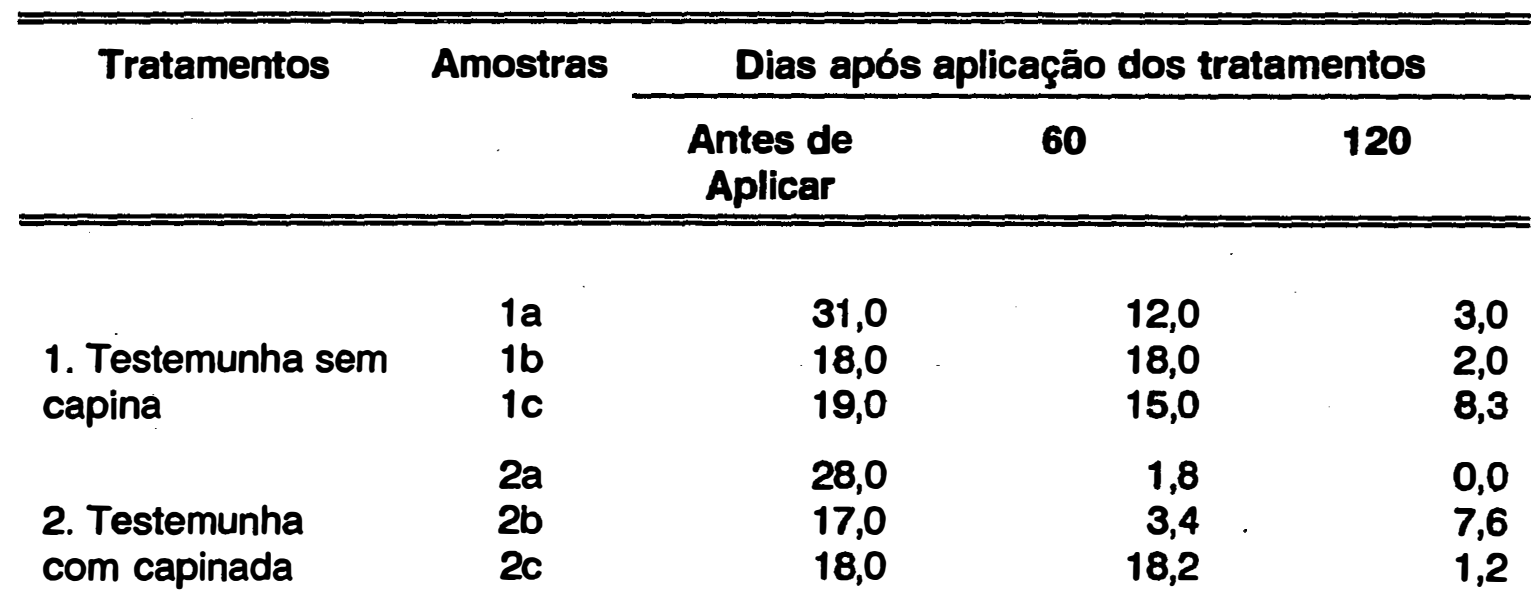


Tabela 6 - Percentagem de colonização micorrízica VA, por 10 seguimentos de raízes coradas com comprimento de $1 \mathrm{~cm}$, colocados sobre lâminas, atribuindo-se notas de 0 (zero) a 100 (cem) ${ }^{\circ}$ - Fazenda Sete Lagoas Conchal - SP, 1990.

\begin{tabular}{llrrr}
\hline \hline & $3 a$ & 17,0 & 0,9 & 0,0 \\
3. Terbacil & 3b & 15,0 & 3,1 & 0,8 \\
& $3 c$ & 11,0 & 6,6 & 1,2 \\
4. Simazine & $4 a$ & 32,0 & 1,6 & 0,7 \\
& $4 b$ & 11,0 & 8,5 & 0,1 \\
& $4 c$ & 28,0 & 7,5 & 2,5 \\
5. Dichlobenil & $5 a$ & 19,0 & 8,9 & 0,9 \\
& $5 b$ & 15,0 & 8,3 & 3,0 \\
6. Diuron & $5 c$ & 26,0 & 15,0 & 4,5 \\
& $6 a$ & 39,0 & 11,0 & 2,0 \\
& $6 b$ & 30,0 & 6,3 & 1,2 \\
7. Bromacil & $6 c$ & 25,0 & 2,4 & 6,0 \\
& $7 a$ & 7,0 & 17,0 & 0,2 \\
8. Bromacil + & $7 b$ & 9,0 & 5,0 & 1,0 \\
Diuron & $7 c$ & 9,0 & 16,5 & 0,0 \\
\hline \hline
\end{tabular}

- Avaliação visual, onde 0 (zero) representa ausência de infecção micorrízica e, 100 (cem) representa raízes totalmente micorrizadas.

A análise estatística mostrou que a diferença entre os oito tratamentos foi significativa com $p=0.00321$, indicando existir pelo menos um tratamento diferente dos demais, da mesma forma que as interaçōes entre tratamentos e tempos, com $p=0.00479$ (Tabela 24, em apêndice).

Se forem considerados as diferenças entre tratamentos sem se considerar as respostas nos diferentes tempos, o teste de TUKEY a $5 \%$ para as médias dos tratamentos mostrou a existência de dois grupos de respostas em ordem decrescente, (i) trat.1, trat.6, trat.5, trat.2, trat.4 e trat.8 e (ii) trat.5, trat.2, trat.4, trat.8, trat.7 e trat.3, como mostra a Tabela 7. 
Tabela 7 - Teste de TUKEY para as médias de tratamentos, sem considerar o tempo para colonização micorrízica VA.

\begin{tabular}{llll}
\hline \multicolumn{1}{c}{ TRATAMENTOS } & MÉDIAS & $5 \%$ & $1 \%$ \\
\hline \hline 1. Testemunha sem capina & 14,033333 & $\mathrm{a}$ & $\mathrm{A}$ \\
6. Diuron & 13,655556 & $\mathrm{a}$ & $\mathrm{AB}$ \\
5. Dichlobenil & 11,177778 & $\mathrm{ab}$ & $\mathrm{AB}$ \\
2. Testemunha com capina & 10,577778 & $\mathrm{ab}$ & $\mathrm{AB}$ \\
4. Simazine & 10,211111 & $\mathrm{ab}$ & $\mathrm{AB}$ \\
8. Bromacil + Diuron & 8,166667 & $\mathrm{ab}$ & $\mathrm{AB}$ \\
7. Bromacil & 7,188889 & $\mathrm{~b}$ & $\mathrm{AB}$ \\
3. Terbacil & 6,177778 & $\mathrm{~b}$ & $\mathrm{~B}$ \\
& & & \\
\hline \hline
\end{tabular}

Médias seguidas por letras distintas diferem entre si ao nivel de significância indicado. D.M.S. $5 \%=5,97365$ - D.M.S. $1 \%=7,49400$

As duas maiores médias sāo para os tratamentos 1 e 6, compreendidos como testemunha com uma capina anual e diuron respectivamente. As duas menores são para os tratamentos 7 (bromacil) e 3 (terbacil), pertencentes ao mesmo grupo químico de herbicida.

Quando se considerou os tempos, verifica-se que a diferença entre os dois grupos descritos era devida ao alto valor das respostas no tempo 1, como pode ser visto na Tabela 8.

Os resultados do teste de TUKEY para as diferenças entre os tratamentos dentro dos tempos estudados, são mostrados nas Tabelas 8, 9 e 10. 
Tabela 8 - Teste de TUKEY para as médias de tratamentos dentro do tempo 1 (antes da aplicaçāo), para colonização micorrizica VA.

\begin{tabular}{llll}
\hline TRATAMENTOS & MÉDIAS & $5 \%$ & $1 \%$ \\
\hline 6. Diuron & 31,333333 & a & A \\
4. Simazine & 23,666667 & ab & AB \\
1. Testemunha sem capina & 22,666667 & ab & ABC \\
2. Testemunha com capina & 21,000000 & abc & ABC \\
5. Dichlobenil & 20,000000 & abcd & ABC \\
3. Terbacil & 14,333333 & bcd & BC \\
8. Bromacil + Diuron & 9,633333 & cd & BC \\
7. Bromacil & 8,333333 & d & C \\
\hline \hline
\end{tabular}

Tabela 9 - Teste de TUKEY para as médias de tratamentos dentro do tempo 2 (60 dias após aplicação), para colonização micorrizica VA.

\begin{tabular}{llll}
\hline \multicolumn{1}{c}{ TRATAMENTOS } & MÉDIAS & $5 \%$ & 1\% \\
\hline 1. Testemunha sem capina & 15,000000 & a & A \\
8. Bromacil + Diuron & 13,133334 & a & A \\
7. Bromacil & 12,833333 & a & A \\
5. Dichlobenil & 10,733333 & a & A \\
2. Testemunha com capina & 7,800000 & a & A \\
6. Diuron & 6,566667 & a & A \\
4. Simazine & 5,866667 & a & A \\
3. Terbacil & 3,533333 & a & A \\
\hline \hline
\end{tabular}


Tabela 10 - Teste de TUKEY para as médias de tratamentos dentro do tempo 3 (120 dias após aplicação), para colonização micorrízica VA.

\begin{tabular}{llll}
\hline \multicolumn{1}{c}{ TRATAMENTOS } & MÉDIAS & 5\% & 1\% \\
\hline \hline & & & \\
1. Testemunha sem capina & 4,433333 & $\mathrm{a}$ & $\mathrm{A}$ \\
6. Diuron & 3,066667 & $\mathrm{a}$ & $\mathrm{A}$ \\
2. Testemunha com capina & 2,933333 & $\mathrm{a}$ & $\mathrm{A}$ \\
5. Dichlobenil & 2,800000 & $\mathrm{a}$ & $\mathrm{A}$ \\
8. Bromacil + Diuron & 1,733333 & $\mathrm{a}$ & $\mathrm{A}$ \\
4. Simazine & 1,100000 & $\mathrm{a}$ & $\mathrm{A}$ \\
3. Terbacil & 0,666667 & $\mathrm{a}$ & $\mathrm{A}$ \\
7. Bromacil & 0,400000 & $\mathrm{a}$ & $\mathrm{A}$ \\
\hline \hline
\end{tabular}

Médias seguidas por letras distintas diferem entre si ao nivel de significância indicado. D.M.S. $5 \%=12,17790$ - D.M.S. $1 \%=14,50381$

O tempo 1, corresponde à primeira amostragem realizada um ano depois da última aplicação. O tempo 2 e 3 correspondem respectivamente, a 60 e 120 dias após a aplicação dos tratamentos do mesmo ano.

O percentual de colonização micorrízica antes da aplicação apresentou a maior média para o tratamento 6 (diuron) e a menor média para o tratamento 7 (bromacil) (Tabela 8).

Alguns pesquisadores têm reportado sobre os efeitos estimulatórios provocados pelos herbicidas na colonizaçāo micorrízica (SMITH \& FERRY, 1979; SPOKES et alii, 1981 e SYLVIA \& SCHENK, 1982). Embora não diferindo estatisticamente dos tratamentos controles, o diuron e a simazine apresentaram maiores médias do que aqueles, indicando um possivel efeito nesse sentido. Verificou-se também que os tratamentos 6 (diuron), 4 (simazine) e 1 (testemunha com uma capina anual) diferiram significativamente dos tratamentos 8 (bromacil + diuron) e 7 (bromacil). A figura 2 
representada pelo diagrama de VENN ilustra os resultados, antes da aplicação ao nível de $5 \%$ de significância.

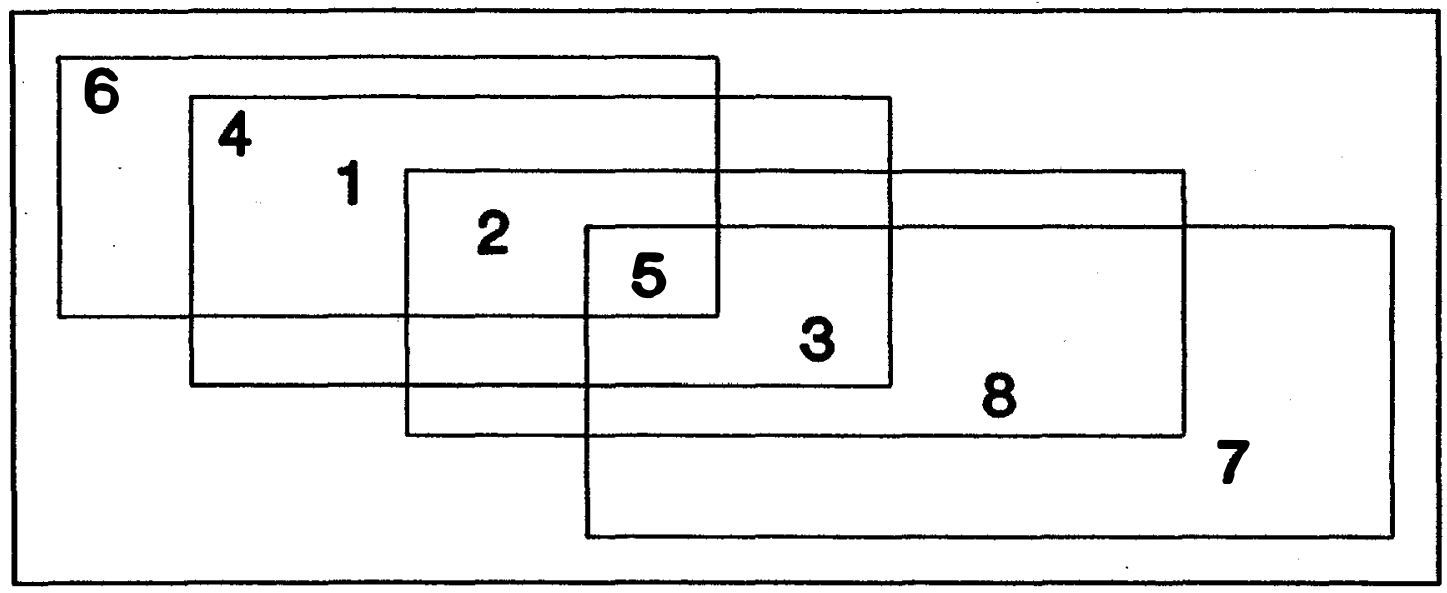

Figura 2 - Diagrama de Venn ilustrativo na diferenciação dos resultados entre os tratamentos, para colonizaçāo micorrízica VA.

Apesar de ter havido a existência de 4 grupos de médias antes da aplicação para, como mostra a Tabela 8 , e a existência de diferenças significativas entre os tratamentos 6, 4 e 1 dos tratamentos 8 e 7, os resultados apresentados dentro de cada grupo de tratamentos e entre grupos de tratamentos, com exceçāo do tratamento 7 (bromacil), mostra que o impacto provocado na colonizaçāo micorrízica VA em citros, pelos herbicidas terbacil, simazine, dichlobenil, diuron e diuron + bromacil, parece ser semelhante ao provocado pela capina manual normal, realizada para o controle de plantas daninhas na cultura do citros.

Verificou-se ainda que o impacto causado pelo bromacil na reduçāo da colonizaçāo micorrizica dos citros foi significativamente superior ao apresentado pela capina manual normal. Para esse herbicida, o resultado foi diferente do obtido por SANTOS (1989), o qual nāo encontrou efeito do mesmo sobre a colonização micorrízica dos citros, quando comparado com o tratamento controle.

Entretanto, de maneira geral, a exceção do bromacil, os resultados são concordantes com os da maioria dos pesquisadores, os quais não observaram efeitos depressivos significativos sobre a colonizaçāo micorrízica MVA, em presença de 
herbicida. Porém, quando encontrados, os efeitos estāo mais diretamente relacionados a cada molécula em particular. Sendo que muitas vezes só foram verificadas nas doses muito acima das normalmente usadas nas condições de campo (SMITH \& FERRY, 1979; OCAMPO \& HAYMAN, 1980 e 1985; SPOKES et alii, 1981; TOMMERUP \& BRIGS, 1981; POPES \& HOLT, 1981; NEMEC \& TUCKER, 1983; GARCIA - ROMERA et alii, 1988).

Para esse tipo de trabalho, as sugestōes de TRAPPE et alii (1984) são pertinentes e necessárias tal como a condução de trabalhos multidiciplinares nesta área.

Como visto, foi devido principalmente as respostas no tempo 1, as diferenças entre os tratamentos. Entretanto analisando-se somente as respostas nos 3 tempos sem considerar os tratamentos, o teste de TUKEY aos niveis de 5 e $1 \%$ agrupou as respostas médias por tempo conforme Tabela 11.

Tabela 11 - Teste de TUKEY para as médias de tempo, sem considerar os tratamentos para colonizaçāo micorrízica VA.

\begin{tabular}{lccc}
\hline \multicolumn{1}{c}{ TEMPOS } & MÉDIAS & $5 \%$ & $1 \%$ \\
\hline \hline & & & \\
TE1. Antes da aplicação & 18,870833 & a & A \\
TE2. 60 dias após aplicação & 9,433333 & b & B \\
TE3. 120 dias após aplicação & 2,141667 & c & C \\
\hline \hline
\end{tabular}

Médias seguidas por letras distintas diferem entre si ao nível de significância indicado. D.M.S. $5 \%=3,64916$ - D.M.S. $1 \%=4,65793$

Discutindo-se as médias, verifica-se que a média do tempo 1 mostrou-se 2 vezes superior a do tempo 2 e 8,82 vezes a do tempo 3.

Os resultados para as diferenças de respostas no tempo dentro de cada tratamento, encontram-se nas Tabelas 25 a 32 no apêndice, podendo-se agrupar as respostas conforme Tabela 12. 
Tabela 12 - Grupos de respostas pelo teste de TUKEY a 5\%, considerando-se 0 tempo para cada tratamento para colonizaçāo micorrízica VA.

TRATAMENTOS

1. Testemunha sem capina

2. Testemunha com capina

3. Terbacil

4. Simazine

5. Dichlobenil

6. Diuron

7. Bromacil

8. Bromacil + Diuron
DIFERENÇAS NOS TEMPOS

TE1 - TE2

TE3

TE1

TE2 $=$ TE3

TE1

TE2 $=$ TE3

TE1

TE2 $=$ TE3

$T E 1=T E 2$

$T E 2=T E 3$

TE1

TE2 $=$ TE3

$T E 2=T E 1$

$\mathrm{TE} 1=\mathrm{TE} 3$

$T E 2=T E 1$

$T E 1=T E 3$

TE1 = Antes da aplicaçāo; TE2 = 60 dias após aplicaçāo; TE3 = 120 dias após aplicaçāo.

Pode-se observar pela Tabela, que para os tratamentos 1, 2, 3, 4, 5 e 6 as maiores médias foram obtidas no tempo 1. No entanto, estas respostas foram significativas somente para os tratamentos 2, 3, 4 e 6, isto é, para os tratamentos 2 (testemunha capinada), 3 (terbacil), 4 (simazine) e 6 (diuron) existe diferença entre as respostas obtidas no tempo $1 \mathrm{em}$ relaçāo às respostas obtidas nos tempos 2 e 3.

Para o tratamento 5 só houve diferença significativa entre as respostas no tempo 1 e no tempo 3. E para o tratamento 1 as respostas obtidas no tempo 1 e 2 não diferiram entre si, mas são diferentes das obtidas no tempo 3. 
Para os tratamentos 7 e 8 as maiores respostas foram obtidas no tempo 2, embora nāo sejam estatisticamente diferentes das respostas obtidas no tempo 1. Entretanto, observou-se que as respostas no tempo 2 para esses tratamentos foram significativamente diferentes daquelas obtidas no tempo 3.

A questāo, no entanto, está em analisar a magnitude do impacto provocado pelo herbicida bromacil, como discutido anteriormente. Assim, confrontando-se o valor da média de colonização dentro do tratamento 7 (bromacil) de 12.83 no tempo 2 (Tabela 31, em apêndice), com as médias de colonizaçāo dentro do tratamento 1 (testemunha com uma capina anual) de 15.00 e 4.43 nos tempos 2 e 3 respectivamente (Tabela 25, em apêndice), e as médias de colonização dentro do tratamento 2 (testemunha capinada) de 7.80 e 2.93 também nos tempos 2 e 3 respectivamente (Tabela 26, em apêndice), verifica-se que o impacto que pode provocar o bromacil, mostrado no tempo 1, frente aos dados obtidos no tempo 2 em comparação com os dados das testemunhas nos tempos 2 e 3, possivelmente deve ser um impacto de pouca importância para a produçāo do citros e simbiose MVA, considerando-se que as respostas da colonizaçāo micorrízica no tempo sāo lentas.

Um outro fator que deve ser analisado nessa discussāo, trata-se da umidade do solo e da adubação NPK realizada no campo experimental no período desse estudo.

Através do balanço hídrico, como mostra a Figura 3, no apêndice, verificou-se deficiência hídrica nos meses de março, abril, maio, junho e julho de 1990, coincidindo com os tempos $2(20 / 3 / 1990)$ e $3(22 / 5 / 1990)$, desse trabalho. Já no tempo 1 (16/1/1990) as condiçōes de umidade foram favoráveis apresentando excedente hídrico.

A colonização micorrízica foi seriamente reduzida nos tempos 2 e 3 em relação ao tempo 1, cujas médias mostraram-se 2 e 8.82 vezes inferiores a do tempo 1 , respectivamente (Tabela 11). No entanto, mesmo sendo favorecido o desenvolvimento micorrízico em condiçōes próximas a capacidade de campo (SIQUEIRA \& FRANCO, 1988), plantas estressadas hidricamente apresentaram maior colonizaçāo como mostra os trabalhos de KHAN (1971); RABATIN (1979); NELSEN \& SAFIR (1982); BOLGIANO et alii (1983) e SAITO et alii (1983), indicando que a falta de umidade possivelmente nāo tenha sido a causa principal da reduçāo micorrizica verificado nos tempos 2 e 3. 
Porém, analisando-se a adubaçāo NPK realizada no campo experimental, utilizando-se a fórmula 12-6-12, na dose de $5 \mathrm{Kg}$ por pé, aplicados parceladamente 3 vezes ao ano, nos meses de julho/agosto, novembro/dezembro e fevereiro/março, e ainda considerando as próprias condiçōes de alto teor de fósforo do solo no local do ensaio, verifica-se que essas condiçōes, somadas ao excedente hídrico observado nos meses de novembro, dezembro, janeiro e fevereiro, ofereceram condiçōes para um bom desenvolvimento dos citros, mas desfavorável a simbiose devido ao teor de fósforo. Possivelmente tenham sido as causas da redução na colonizaçāo micorrízica observada nos tempos 2 e 3 em relação ao tempo 1. Como mostram os tratamentos controles nos três tempos estudados verificando-se médias para o tratamento 1 respectivamente 22.66; 15.00 e 4.43, diferindo nesse caso significativamente apenas no tempo 3. Para o tratamento 2 as médias foram 21.00; 7.80 e 2.93, sendo estatisticamente diferentes os tempos 2 e 3 do tempo 1, os quais nāo diferiram entre si (Tabela 25 e 26, em apêndice). Evidencia-se dessa forma, como discutido anteriormente, que o impacto apresentado pelo herbicida bromacil deve ser inferior ao provocado pela interaçāo adubaçāo, e teor de umidade do solo.

\subsection{Quantificação da população de esporos MVA}

Os esporos, como é de conhecimento geral, são estruturas de repouso pelas quais os fungos sobrevivem a diferentes tipos de estresses ambientais.

Um solo com abundância de esporos micorrízicos e, as condiçōes ambientais estando favoráveis ao desenvolvimento da simbiose, as plantas de citros poderāo se apresentar micorrizadas e serāo favorecidas pelos efeitos benéficos dessa associação.

Vários fatores podem afetar diferentemente o número de esporos micorrizicos da regiāo de desenvolvimento das raizes do citros. Discute-se nesse trabalho, o efeito de diferentes herbicidas aplicados a longo prazo, isto é, o mesmo produto aplicado anualmente sempre no mesmo local. Os resultados dessa variável em questão (Tabela 13), indicou pela análise de variância (Tabela 33, em apéndice) que a diferença entre os oito tratamentos foi significativa com $p=0.075$, existindo a esse nivel pelo menos um tratamento diferente dos demais. Se for considerado o nivel de significância tradicional 
$\alpha=0.05$, não se verificam diferenças significativas entre os tratamentos. Para os tempos, os resultados obtidos foram significativos com $p=0.00001$, no entanto as interaçōes entre tratamento e tempo nāo foram significativas, com $p=0.11$, como mostra a Tabela 33, em apêndice.

Tabela 13 - Resultados do número de esporos MVA, na região de desenvolvimento das raízes de citros por $50 \mathrm{ml}$ de solo - Fazenda Sete Lagoas - Conchal SP, 1990.

\begin{tabular}{|c|c|c|c|c|c|}
\hline \multicolumn{2}{|c|}{ Tratamentos } & \multirow[t]{2}{*}{ Amostras } & \multicolumn{3}{|c|}{ Dias após aplicação dos tratamentos } \\
\hline & & & Antes de Aplicar & 60 & 120 \\
\hline 1. & $\begin{array}{l}\text { Testemunha sem } \\
\text { capina }\end{array}$ & $\begin{array}{l}1 a \\
1 b \\
1 c\end{array}$ & $\begin{array}{l}620 \\
431 \\
414\end{array}$ & $\begin{array}{c}669 \\
862 \\
1114\end{array}$ & $\begin{array}{l}432 \\
579 \\
809\end{array}$ \\
\hline 2. & $\begin{array}{l}\text { Testemunha com } \\
\text { capinada }\end{array}$ & $\begin{array}{l}2 a \\
2 b \\
2 c\end{array}$ & $\begin{array}{l}430 \\
342 \\
542\end{array}$ & $\begin{array}{c}904 \\
1400 \\
808\end{array}$ & $\begin{array}{l}816 \\
817 \\
853\end{array}$ \\
\hline 3. & Terbacil & $\begin{array}{l}3 a \\
3 b \\
3 c\end{array}$ & $\begin{array}{l}792 \\
604 \\
546\end{array}$ & $\begin{array}{c}1137 \\
1250 \\
878\end{array}$ & $\begin{array}{c}1226 \\
827 \\
824\end{array}$ \\
\hline 4. & Simazine & $\begin{array}{l}4 a \\
4 b \\
4 c\end{array}$ & $\begin{array}{l}911 \\
502 \\
650\end{array}$ & $\begin{array}{c}1078 \\
1164 \\
776\end{array}$ & $\begin{array}{l}956 \\
666 \\
624\end{array}$ \\
\hline 5. & Dichlobenil & $\begin{array}{l}5 a \\
5 b \\
5 c\end{array}$ & $\begin{array}{l}586 \\
776 \\
456\end{array}$ & $\begin{array}{c}1116 \\
1362 \\
396\end{array}$ & $\begin{array}{l}683 \\
487 \\
444\end{array}$ \\
\hline 6. & Diuron & $\begin{array}{l}6 a \\
6 b \\
6 c\end{array}$ & $\begin{array}{l}896 \\
720 \\
628\end{array}$ & $\begin{array}{l}890 \\
740 \\
772\end{array}$ & $\begin{array}{l}779 \\
490 \\
379\end{array}$ \\
\hline 7. & Bromacil & $\begin{array}{l}7 a \\
7 b \\
7 c\end{array}$ & $\begin{array}{l}706 \\
600 \\
688\end{array}$ & $\begin{array}{l}1316 \\
1620 \\
1137\end{array}$ & $\begin{array}{c}1258 \\
529 \\
415\end{array}$ \\
\hline 8. & $\begin{array}{l}\text { Bromacil + } \\
\text { Diuron }\end{array}$ & $\begin{array}{l}8 a \\
8 b\end{array}$ & $\begin{array}{l}666 \\
688\end{array}$ & $\begin{array}{l}717 \\
973\end{array}$ & $\begin{array}{l}400 \\
506\end{array}$ \\
\hline
\end{tabular}


Por essas respostas, considerando-se $\alpha=0.05$, o impacto provocado pelos tratamentos herbicidas no número de esporos na regiāo de desenvolvimento das raízes de citros não diferiram significativamente dos tratamentos controles, concordando com os trabalhos de OCAMPO \& HAYMANN (1980) e SANTOS (1989).

Através do teste de TUKEY, buscou-se então localizar as diferenças entre as respostas nos tempos, conforme Tabela 14 abaixo.

Tabela 14- Teste de TUKEY para as médias de tempo, sem considerar os tratamentos, para número de esporos micorrízicos VA.

\begin{tabular}{llll}
\hline \multicolumn{1}{c}{ TEMPOS } & MÉDIAS & 5\% & 1\% \\
\hline \hline & & & \\
TE2. 60 dias após aplicação & 985,666667 & a & A \\
TE3. 120 dias após aplicaçāo & 671,666667 & b & B \\
TE1. Antes da aplicação & 616,458333 & b & B \\
\hline \hline
\end{tabular}

Médias seguidas por letras distintas diferem entre si ao nivel de significância indicado. D.M.S. $5 \%=134,94848$ - D.M.S. $1 \%=172,25320$

Verificou-se portanto que as diferenças entre os tempos foram devidas ao alto valor das respostas no tempo 2, não havendo entretanto, diferenças significativas entre as respostas nos tempos 3 e 1, indicando que o impacto sofrido pela colonização micorrizica, conforme referido anteriormente, em funçāo da adubação, umidade e secagem de alguma forma favoreceu a esporulação.

Este fato se mostra mais evidente quando se compara os valores das médias do número de esporos dentro dos tratamentos 1 e 2 (controles), como se observa na Tabela 15, construida a partir do teste de TUKEY para médias de número de esporos dentro de cada tratamento do fator tratamento, contidos nas Tabelas de 34 à 41 , em apêndice. 
Tabela 15 - Comparação de médias dos tratamentos nos tempos estudados, para número de esporos MVA.

\begin{tabular}{lrrr}
\hline \multicolumn{1}{c}{ TRATAMENTOS } & \multicolumn{3}{c}{ TEMPOS } \\
\cline { 2 - 4 } & \multicolumn{1}{c}{ TE1 } & \multicolumn{1}{c}{ TE2 } & \multicolumn{1}{c}{ TE3 } \\
\hline \hline 1. Testemunha sem capina. & 488,33 & 881,67 & 606,67 \\
2. Testemunha com capina. & 438,00 & 1037,33 & 828,67 \\
3. Terbacil & 647,33 & 1088,33 & 959,00 \\
4. Simazine & 687,67 & 1006,00 & 748,67 \\
5. Dichlobenil & 606,00 & 958,00 & 538,00 \\
6. Diuron & 748,00 & 800,67 & 549,33 \\
7. Bromacil & 664,67 & 1357,67 & 734,00 \\
8. Bromacil + Diuron & 651,67 & 755,67 & 409,00 \\
\hline \hline
\end{tabular}

TE1 = Antes da aplicação; TE2 = 60 dias após aplicação; TE3 = 120 dias após aplicaçāo.

KUCEY \& PAUL (1983) afirmam que toda prática que reduz a densidade e o potencial das raízes do hospedeiro, também reduz o número de esporos encontrados no solo, tal como ocorre, inevitavelmente, com a capina manual na eliminação das plantas daninhas, onde o potencial de raízes do hospedeiro, tanto das plantas de citros como das próprias plantas daninhas hospedeiras são reduzidos. Através da Tabela 15 verifica-se para a maioria dos tratamentos um aumento real nas médias do número de esporos, no tempo 2 e decréscimo no tempo 3, porém ambos superiores ao tempo 1 , verificados, especialmente, nos tratamentos 1 e 2 (controles). Esses tratamentos (TE1 e TE2), que representam as condiçōes propostas pelos autores citados acima, diferiram significativamente no tempo 2 dos tempos 1 e 3 e foram no tempo 2 em relação ao tempo 1, 1.8 e 2.4 vezes superiores respectivamente. Entretanto, para os tempos $1 \mathrm{e}$ 3, o número de esporos não diferiram entre si, no entanto as médias dos citados tratamentos foram 1.2 e 1.9 vezes superiores no tempo 3 em relação ao tempo 1 . 
Nesta discussāo, desconsiderando-se os efeitos dos herbicidas, avalia-se o efeito das condiçōes ambientais, umidade + adubaçāo NPK seguida de secagem no número de esporos MVA do citros, efeito este caracterizado pelo aumento do número de esporos nos tratamentos controles, como mostra a Tabela 15.

Para solos com nivel médio de fósforo SYLVIA \& SCHENK (1983), verificaram que a aplicação de adubo fosfatado aumentou a eficiência de esporulaçāo de Gigaspora margarita e Gigaspora heterogama, no entanto, diminuiu significativamente a eficiência de esporulaçāo de Glomus etunicatum e Glomus macrocarpum, indicando respostas diferentes da adubaçāo fosfatada para diferentes gêneros. Em condiçōes de seca KHAN (1971) observou Ipomoea carnea alta densidade de esporos, sendo que - número de esporos correlacionou-se negativamente com a umidade do solo e ocorre, inte com o crescimento da planta (ANDERSON et alii, 1983). Concluindo, SIQUEIRA \& FRANCO (1988) afirmam que alternância entre ciclos de umidade e secagem parece favorecer a esporulação dos fungos MVA.

Nas condiçōes desse estudo, os resultados obtidos se assemelham aos verificados pelos autores citados acima, caracterizado pelo aumento no número de esporos da regiāo de desenvolvimento das raízes do citros, em funçāo da interaçāo umidade + adubação fosfatada seguida de secagem.

Isolados e classificados os esporos, sugere-se estudos de germinaçāo e capacidade infectiva dos mesmos, em raizes de citros, procurando-se quantificar e qualificar possiveis efeitos desses herbicidas sobre os mesmos.

No estudo da relaçāo entre percentagem de colonizaçāo micorrízica nas raízes e o número de esporos MVA do citros nāo se verificou correlaçāo significativa, com coeficiente de correlação igual a $r=-0,129698$.

\subsection{Atividade da microflora heterotrófica do solo}

A atividade microbiana do solo resulta da somatória da atividade das células individuais, que pode ser estimada através de mediçōes do metabolismo global do solo ou da quantificação por processos específicos (SIQUEIRA \& FRANCO, 1988). 
Dentre os métodos existentes, a taxa de respiração ou respiração edáfica, que é medida pela liberação de $\mathrm{CO}_{2}$ ou consumo de $\mathrm{O}_{2}$ oriunda da atividade microbiana heterotrófica do solo, fornece informaçōes úteis sobre as transformaçōes das populaçōes microbianas, decorrentes de práticas agrícolas, como os efeitos de aplicações de herbicidas.

Os dados originais são apresentados na Tabela 16.

Tabela 16 - Atividade microbiana heterotrófica do solo, medida através da radiorespirometria, pela evolução do $\mathrm{CO}_{2}$ liberado pelo consumo de $\mu \mathrm{mol}$ glicose por grama de solo fresco por hora - Fazenda Sete Lagoas Conchal - SP, 1990.

\begin{tabular}{|c|c|c|c|c|c|c|c|}
\hline \multicolumn{2}{|c|}{ Tratamentos } & \multirow{2}{*}{$\begin{array}{c}\text { Amostras } \\
1 a \\
1 b \\
1 c\end{array}$} & \multicolumn{5}{|c|}{ Dias após aplicação dos tratamentos } \\
\hline 1. & $\begin{array}{l}\text { Testemunha sem } \\
\text { capina }\end{array}$ & & $\begin{array}{c}\begin{array}{c}\text { Antes de } \\
\text { Aplicar }\end{array} \\
65,2 \\
66,7 \\
48,7\end{array}$ & $\begin{array}{r}2 \\
\begin{array}{r}112,2 \\
89,1 \\
111,8\end{array}\end{array}$ & $\begin{array}{l}30 \\
46,0 \\
47,8 \\
40,4\end{array}$ & $\begin{array}{c}60 \\
46,4 \\
34,4 \\
42,6\end{array}$ & $\begin{array}{r}120 \\
38,5 \\
36,0 \\
29,3\end{array}$ \\
\hline 2. & $\begin{array}{l}\text { Testemunha com } \\
\text { capinada }\end{array}$ & $\begin{array}{l}2 a \\
2 b \\
2 c\end{array}$ & $\begin{array}{l}52,5 \\
61,1 \\
49,7\end{array}$ & $\begin{array}{l}137,6 \\
102,8 \\
128,3\end{array}$ & $\begin{array}{l}44,2 \\
34,2 \\
33,2\end{array}$ & $\begin{array}{l}22,4 \\
32,4 \\
40,6\end{array}$ & $\begin{array}{l}28,0 \\
31,9 \\
36,3\end{array}$ \\
\hline 3. & Terbacil & $\begin{array}{l}3 a \\
3 b \\
3 c\end{array}$ & $\begin{array}{l}81,1 \\
57,4 \\
49,5\end{array}$ & $\begin{array}{l}62,6 \\
63,7 \\
95,9\end{array}$ & $\begin{array}{l}61,8 \\
53,2 \\
49,0\end{array}$ & $\begin{array}{l}41,2 \\
42,7 \\
38,2\end{array}$ & $\begin{array}{l}34,8 \\
31,2 \\
27,6\end{array}$ \\
\hline 4. & Simazine & $\begin{array}{l}4 a \\
4 b \\
4 c\end{array}$ & $\begin{array}{l}56,0 \\
51,1 \\
54,2\end{array}$ & $\begin{array}{l}53,8 \\
63,8 \\
73,5\end{array}$ & $\begin{array}{l}46,4 \\
42,4 \\
44,6\end{array}$ & $\begin{array}{l}39,8 \\
56,2 \\
42,9\end{array}$ & $\begin{array}{l}30,4 \\
27,7 \\
37,8\end{array}$ \\
\hline 5. & Dichlobenil & $\begin{array}{l}5 a \\
5 b \\
5 c\end{array}$ & $\begin{array}{l}47,1 \\
52,4 \\
47,2\end{array}$ & $\begin{array}{l}58,5 \\
68,8 \\
68,9\end{array}$ & $\begin{array}{l}31,8 \\
43,4 \\
50,0\end{array}$ & $\begin{array}{l}58,5 \\
54,9 \\
48,4\end{array}$ & $\begin{array}{l}39,6 \\
36,8 \\
35,3\end{array}$ \\
\hline 6. & Diuron & $\begin{array}{l}6 a \\
6 b \\
6 c\end{array}$ & $\begin{array}{l}84,2 \\
61,0 \\
44,5\end{array}$ & $\begin{array}{l}70,7 \\
69,2 \\
80,1\end{array}$ & $\begin{array}{l}58,0 \\
36,4 \\
43,2\end{array}$ & $\begin{array}{l}48,0 \\
47,4 \\
37,1\end{array}$ & $\begin{array}{l}36,9 \\
35,4 \\
40,8\end{array}$ \\
\hline 7. & Bromacil & $\begin{array}{l}7 a \\
7 b \\
7 c\end{array}$ & $\begin{array}{l}51,4 \\
56,5 \\
49,9\end{array}$ & $\begin{array}{l}77,3 \\
69,4 \\
74,0\end{array}$ & $\begin{array}{l}43,2 \\
39,0 \\
35,6\end{array}$ & $\begin{array}{l}30,6 \\
44,7 \\
51,3\end{array}$ & $\begin{array}{l}41,2 \\
35,0 \\
38,9\end{array}$ \\
\hline 8. & $\begin{array}{l}\text { Bromacil + } \\
\text { Diuron }\end{array}$ & $\begin{array}{l}8 a \\
8 b\end{array}$ & $\begin{array}{l}42,3 \\
43,4\end{array}$ & $\begin{array}{l}55,8 \\
54,4\end{array}$ & $\begin{array}{l}43,8 \\
42,6\end{array}$ & $\begin{array}{l}46,0 \\
48,0\end{array}$ & $\begin{array}{l}53,9 \\
48,1\end{array}$ \\
\hline
\end{tabular}


Nas condiçōes em que foi desenvolvido o ensaio, a análise de variância indicou que a diferença entre os oito tratamentos foi significativa com $p=0.029$, indicando que existiu pelo menos um tratamento diferente dos demais. Também os resultados obtidos nos diferentes tempos foram significativos com $p=0.00001$, da mesma forma que as interaçōes entre tratamentos e tempos, como mostra a Tabela 42 do quadro de análise de variância, em apêndice.

Pelo confronto das médias, através do teste de TUKEY verificou-se que estas eram devidas aos altos valores das respostas no tempo 2.

A atividade da microflora heterotrófica do solo teve a mesma resposta para todos os tratamentos nos tempos 1, 3 e 5 (Tabelas 17, 18 e 19).

Tabela 17 - Teste de TUKEY para as médias de tratamentos dentro do tempo 1 (antes da aplicação), para atividade da microflora heterotrófica do solo.

6. Diuron

63,233332

a

A

3. Terbacil

62,666667

a

A

1. Testemunha sem capina

60,199998

a

A

2. Testemunha com capina

54,433333

a

A

4. Simazine

53,766666

a

A

7. Bromacil

52,600001

a

A

5. Dichlobenil

48,900000

a

A

8. Bromacil + Diuron

44,833333

a 
Tabela 18 - Teste de TUKEY para as médias de tratamentos dentro do tempo 3 (30 dias após aplicação), para atividade da microflora heterotrófica do solo.

\begin{tabular}{llll}
\hline \multicolumn{1}{c}{ TRATAMENTOS } & MÉDIAS & 5\% & 1\% \\
\hline \hline 3. Terbacil & 54,666667 & $\mathrm{a}$ & $\mathrm{A}$ \\
6. Diuron & 45,866667 & $\mathrm{a}$ & $\mathrm{A}$ \\
1. Testemunha sem capina & 44,733334 & $\mathrm{a}$ & $\mathrm{A}$ \\
4. Simazine & 44,466667 & $\mathrm{a}$ & $\mathrm{A}$ \\
8. Bromacil + Diuron & 42,333332 & $\mathrm{a}$ & $\mathrm{A}$ \\
5. Dichlobenil & 41,733334 & $\mathrm{a}$ & $\mathrm{A}$ \\
7. Bromacil & 39,266666 & $\mathrm{a}$ & $\mathrm{A}$ \\
2. Testemunha com capina & 37,200001 & $\mathrm{a}$ & $\mathrm{A}$ \\
\hline \hline
\end{tabular}

Tabela 19 - Teste de TUKEY para as médias de tratamentos dentro do tempo 5 (120 dias após aplicaçāo), para atividade da microflora heterotrófica do solo.

\section{TRATAMENTOS}

MÉDIAS

$5 \%$

$1 \%$

\begin{tabular}{llll} 
8. Bromacil + Diuron & 51,199999 & a & A \\
7. Bromacil & 38,366667 & a & A \\
6. Diuron & 37,700001 & a & A \\
5. Dichlobenil & 37,233332 & a & A \\
1. Testemunha sem capina & 34,600000 & a & A \\
2. Testemunha com capina & 32,066666 & a & A \\
4. Simazine & 31,966667 & a & A \\
3. Terbacil & 31,200000 & a & A \\
\hline
\end{tabular}

Médias seguidas por letras distintas diferem entre si ao nível de significância indicado. D.M.S. $5 \%=20,99542$ - D.M.S. $1 \%=24,75396$ 
No tempo 2 (Tabela 20), os tratamentos 1 e 2 (controles) foram os que apresentaram maior atividade média, diferenciando-se significativamente aos niveis de 5 e $1 \%$ dos demais, os quais não mostraram diferenças significativas entre si.

Tabela 20 - Teste de TUKEY para as médias de tratamentos dentro do tempo 2 (2 dias após aplicaçāo dos tratamentos), para atividade da microflora heterotrófica do solo.

\begin{tabular}{llll}
\hline \multicolumn{1}{c}{ TRATAMENTOS } & MÉDIAS & 5\% & 1\% \\
\hline \hline 2. Testemunha com capina & 122,900004 & a & A \\
1. Testemunha sem capina & 104,366666 & a & A \\
3. Terbacil & 74,066667 & b & B \\
7. Bromacil & 73,566668 & b & B \\
6. Diuron & 73,333331 & b & B \\
5. Dichlobenil & 65,400002 & b & B \\
4. Simazine & 63,699999 & b & B \\
8. Bromacil + Diuron & 59,033334 & b & B \\
\hline \hline
\end{tabular}

Analisando-se as médias antes da aplicação sem se considerar a inexistência de significância entre os tratamentos, como se observa na Tabela 17, verifica-se que a maior média foi para o tratamento 6 (diuron) 63.23, a menor para 0 tratamento 8 (bromacil + diuron) 44.83, e os tratamentos 1 e 2 (controles) apresentaram médias de 60.20 e 54.43 respectivamente. Esses valores devem representar o estado de equilíbrio microbiológico do solo, após 1 ano da última aplicação dos tratamentos, em funçāo do impacto provocado por ocasiāo da aplicação dos mesmos.

Para a respiraçāo do solo nas condiçōes desta época estudada (tempo 1), nāo se observou relaçāo direta de influência entre os dados observados com os fatores climáticos, como mostra o balanço hídrico (figura 3 , em apêndice), podendo-se 
considerar a ocorrência de um ano normal, no més dessa avaliação, comparado aos anos anteriores no mesmo periodo.

Os dados permitem afirmar, nas condiçōes desse ensaio, que após um ano da última aplicação desses herbicidas estudados precedidos de uma aplicaçāo anual por doze anos ininterruptos, os mesmos apresentam efeitos semelhantes aos tratamentos controles para atividade heterotrófica do solo.

Realizada a avaliação do tempo 1, como se sabe, o experimento foi totalmente capinado manualmente, e o resíduo da capina retirado do local, de tal forma que o solo ficou completamente sem vegetaçāo. Nessas condiçōes, os tratamentos do ano desse estudo foram aplicados, imediatamente após a limpeza do ensaio.

Dois dias após a aplicação dos tratamentos procedeu-se então a avaliação do tempo 2 (Tabela 20).

Nesse tempo, como descrito anteriormente, os tratamentos 1 e 2 (controles) foram os que apresentaram maior atividade heterotrófica, suas médias foram respectivamente 122.90 e 104.37, as quais, como visto, diferiram significativamente das demais, inclusive ao nivel de significância de 1\% (Tabela 20).

Para os tratamentos herbicidas a maior média foi para o tratamento 3 (terbacil) 74.06 e a menor média para o tratamento 8 (bromacil + diuron) 59.03. Os valores dos tratamentos controles evidenciam uma alta atividade microbiana para os mesmos, ao passo que os tratamentos herbicidas foram significativamente inferiores a esses. Contudo, mostraram-se levemente superiores a si e aos controles, quando comparadas suas médias no tempo 2 com as médias obtidas no tempo 1, como mostram as Tabelas 17 e 20.

A explicação encontrada para esse fenômeno verificado no tempo 2 nos tratamentos 1 e 2 (controles), possivelmente, tenha sido devido a incorporação de material orgânico oriundo dos sistemas radiculares das plantas daninhas, os quais não foram retirados com o cultivo manual e limpeza do ensaio. Constituindo-se em material prontamente disponivel para determinados grupos de microrganismos heterotróficos decompositores.

Confrontando-se esses dados com os da literatura revisada, esse aumento da atividade microbiana provocado pelo cultivo do solo nos tratamentos 1 e 2 pode ser 
preocupante, pois MARTEL (1970) atribuiu a degradação do solo principalmente em climas tropicais ao cultivo, que somada às altas temperaturas e umidade favorecem a intensa atividade microbiana o que resulta numa alta degradação da matéria orgânica, bem como num declínio da sua estrutura do solo.

Este fato também se verificou com os tratamentos herbicidas, porém em pequena intensidade, talvez, devido ao ajustamento da populaçāo microbiana no solo, que se dá após a aplicaçāo de um herbicida. Ajustamento este, conhecido como "fase lag", ocorrendo possivelmente, de uma a duas semanas após a aplicaçāo do herbicida, onde a concentração do produto no solo nāo é afetada significativamente como afirmam ALEXANDER (1965) e KAUFMAN \& KEARNEY (1976).

Por este raciocínio, se detecta um possível efeito benéfico dos herbicidas estudados, ou seja, o de atuarem como agentes moderadores da atividade microbiana heterotrófica do solo. Porém, isso precisa ser melhor qualificado, sugerindo-se estudos nas frações da matéria orgânica do solo.

No tempo 4, o teste de TUKEY a 5\% de significância mostrou a existência de dois grupos de respostas, com um grande número de coincidências nos dois grupos, como mostra a Tabela 21. Foram diferentes o tratamento 5 (dichlobenil) com alta média de resposta e o tratamento 2 (testemunha capinada) com baixa média de respostas.

Tabela 21 - Teste de TUKEY para as médias de tratamentos dentro do tempo 4 (60 dias após aplicação), para atividade da microflora heterotrófica do solo.

\begin{tabular}{llll}
\hline \multicolumn{1}{c}{ TRATAMENTOS } & MÉDIAS & 5\% & 1\% \\
\hline 5. Dichlobenil & 53,933334 & $\mathrm{a}$ & $\mathrm{A}$ \\
8. Bromacil + Diuron & 48,166667 & $\mathrm{ab}$ & $\mathrm{A}$ \\
4. Simazine & 46,300001 & $\mathrm{ab}$ & $\mathrm{A}$ \\
6. Diuron & 44,166667 & $\mathrm{ab}$ & $\mathrm{A}$ \\
7. Bromacil & 42,200000 & $\mathrm{ab}$ & $\mathrm{A}$ \\
1. Testemunha sem capina & 41,133334 & $\mathrm{ab}$ & $\mathrm{A}$ \\
3. Terbacil & 40,700001 & $\mathrm{ab}$ & $\mathrm{A}$ \\
2. Testemunha com capina & 31,800000 & $\mathrm{~b}$ & $\mathrm{~A}$ \\
\hline \hline
\end{tabular}


Observando-se os dados coletados no campo pode-se verificar que as respostas obtidas para o tratamento 5 (dichlobenil) neste tempo foram, para 2 das 3 repetiçōes muito superiores a todas as respostas obtidas, com exceçāo de uma resposta do tratamento 4.

0 oposto ocorreu para uma resposta do tratamento 2 (testemunha capinada) na primeira repetiçāo. Estes três pontos podem ser considerados pontos discrepantes. Não há, teoricamente, nenhuma razāo para que estes valores se diferenciassem do conjunto de resposta (Tabela 16). De qualquer forma, suas médias de respostas foram 53.93 e 31.80 respectivamente, mostrando que a atividade da microflora heterotrófica do solo, para esse tempo estudado, foi próxima da atividade obtida no tempo 1. Possivelmente, a maior contribuiçāo no sentido de uma menor atividade heterotrófica, seja atribuido as condiçōes de falta de umidade no solo.

Os resultados observados da atividade heterotrófica do solo nesse estudo, estāo de acordo com os obtidos pela maioria dos pesquisadores, onde, um herbicida poderá exercer um efeito na microflora heterotrófica do solo, influenciando a variabilidade natural do sistema, considerando-se o cultivo do solo como um impacto normal e natural num sistema agrícola (AU, 1968; LIU \& CIBES - VIADÉ, 1972; DESHMUKH \& SHRIKHANDE, 1974; GROSSBARD \& MARSH, 1974; GROSSBARD, 1976; COLE, 1976; GROSSBARD \& DAVIES, 1976; LEWIS et alii, 1978; ANDERSON, 1978; DAVET, 1981 e DUAH - YENTUMI \& JOHNSON, 1986).

Por outro lado, quando se comparou somente os tempos sem se considerar os tratamentos, o teste TUKEY, revelou a 5\% de significância, a existência de 4 grupos de resposta: (i) tempo 2, (ii) tempo 1, (iii) tempos 3 e 4 (iv) tempos 4 e 5, como móstra a Tabela 22. 
Tabela 22 - Teste de TUKEY para as médias de tempo sem considerar os tratamentos para atividade da microflora heterotrófica do solo.

\begin{tabular}{lccc}
\hline \multicolumn{1}{c}{ TRATAMENTOS } & MÉDIAS & $5 \%$ & $1 \%$ \\
\hline TE2. 2 dias após aplicação & 79,545834 & $\mathrm{a}$ & $\mathrm{A}$ \\
TE1. Antes da aplicaçao & 55,079166 & $\mathrm{~b}$ & $\mathrm{~B}$ \\
TE3. 30 dias após aplicação & 43,783333 & $\mathrm{C}$ & $\mathrm{C}$ \\
TE4. 60 dias após aplicação & 43,550000 & $\mathrm{~cd}$ & $\mathrm{C}$ \\
TE5. 120 dias após aplicação & 36,791667 & $\mathrm{~d}$ & $\mathrm{C}$ \\
\hline \hline
\end{tabular}

Médias seguidas por letras distintas diferem entre si ao nível de significância indicado D.M.S. $5 \%=6,89767$ - D.M.S. $1 \%=8,34698$

De fato, a maior atividade microbiana se deu no tempo 2 ( 2 dias após aplicação), diferindo significativamente das respostas nos demais tempos. A seguinte maior resposta que se distingüiu significativamente dos demais tempos foi encontrada no tempo 1. Não se encontrou diferença significativa entre as respostas nos tempos 3 e 4, como também não houve tal diferença entre os tempos 4 e 5 . 0 tempo 5 foi o que apresentou a menor média de atividade microbiana.

Porém, quando comparados os tempos dentro de cada tratamento, verifica-se através do teste de TUKEY a $5 \%$ de significância, as diferenças mostradas na Tabela 23. 
Tabela 23 - Grupos de respostas pelo teste de TUKEY a 5\%, considerando-se 0 tempo dentro de cada tratamento para atividade da microflora heterotrófica do solo.

\begin{tabular}{|c|c|}
\hline TRATAMENTOS & DIFERENÇAS \\
\hline 1. Testemunha sem capina & $\begin{array}{c}\text { TE2 } \\
T E 1=T E 3=T E 4 \\
T E 3=T E 4=T E 5\end{array}$ \\
\hline 2. Testemunha com capina & $\begin{array}{c}\text { TE2 } \\
\text { TE1 }=\text { TE3 } \\
\text { TE3 }=\text { TE5 }=\text { TE4 }\end{array}$ \\
\hline 3. Terbacil & $\begin{array}{c}\text { TE2 }=T E 1=T E 3 \\
T E 3=T E 4 \\
\text { TE4 }=\text { TE5 }\end{array}$ \\
\hline 4. Simazine & $\begin{array}{c}\text { TE2 }=\text { TE } 1=T E 4=T E 3 \\
\text { TE4 }=\text { TE3 }=\text { TE5 }\end{array}$ \\
\hline 5. Dichlobenil & $\begin{array}{c}\text { TE2 }=\text { TE4 }=\text { TE1 } \\
T E 4=T E 1=T E 3=T E 5\end{array}$ \\
\hline 6. Diuron & $\begin{array}{c}\text { TE2 }=\text { TE1 } \\
\text { TE1 }=\text { TE3 }=\text { TE4 } \\
\text { TE3 }=\text { TE4 }=\text { TE5 }\end{array}$ \\
\hline 7. Bromacil & $\begin{array}{c}\text { TE2 } \\
T E 1=T E 4=T E 3=T E 5\end{array}$ \\
\hline 8. Bromacil + Diuron & Não há \\
\hline
\end{tabular}

TE1 = Antes da aplicaçāo; TE2 $=2$ dias após aplicação; TE3 = 30 dias após aplicação; TE4 = 60 dias após aplicação; TE5 $=120$ dias após aplicaçāo.

Para todos os tratamentos a maior atividade da microflora heterotrófica de solo foi no tempo 2, sendo significativamente diferentes dos demais tempos para os tratamentos 1, 2 e 7 (controles e bromacil), respectivamente.

As menores respostas observadas foram no tempo 5 , com exceção dos tratamentos 2 e 8, respectivamente, testemunha capinada e bromacil + diuron.

Para todos os tratamentos não houveram diferenças significativas entre os tempos 4 e 5 . O mesmo se verificou para todos os tratamentos nos tempos 3 e 4. 
Para todos os tratamentos as respostas no tempo 1 foram iguais às do tempo 3 , indicando que o desequilíbrio provocado pelo efeito de cultivo do solo nas condiçōes desse ensaio, como discutido anteriormente, nāo foi superior a 30 dias, uma vez que o tempo 3 representa justamente o período de dias entre a limpeza do experimento com imediata aplicaçāo dos tratamentos e sua avaliaçāo. Pode-se também observar através da Figura 3 , que neste período as condiçōes climáticas foram favoráveis, com o solo apresentando excedente hídrico.

Com exceção dos tratamentos 2 e 3, respectivamente, testemunha capinada e terbacil, a atividade da microflora foi igual nos tempos 1, 3 e 4. Também com exceção do tratamento 3 (terbacil) as respostas dos tratamentos nos tempos 3, 4 e 5 foram iguais.

Os valores obtidos para os tratamentos 2 e 3 nos tempos 1, 3, 4 e 5 foram, respectivamente 54.43, 37.20, 31.80 e 32.07 para o tratamento 2 e 62.67, 54.67, 40.70 e 31.20 para 0 tratamento 3 . Nesses mesmos tempos, os valores verificados para 0 tratamento 1 (testemunha com um capina anual) foram, respectivamente, 60.20, 44.73, 41.13 e 34.60 , mostrando valores muito semelhantes dentro de cada tempo, entre os tratamentos 1 e 3 (Tabelas 43, 44 e 45, em apêndice).

Verificou-se também que os demais tratamentosherbicidas, componentes desse estudo, nāo contrastaram dessas médias de respostas.

Esses dados além de suportarem as discussōes anteriores, confirmam que esses herbicidas podem atuar como produtos estabilizadores ou reguladores da atividade microbiana heterotrófica do solo, como se mostra evidente, quando se compara as médias de respostas desses herbicidas nos diferentes tempos, contra as médias de respostas dos tratamentos controles no tempo 2.

Para os tratamentos $3,4,5,6$ e 8 respectivamente, terbacil, simazine, dichlobenil, diuron e bromacil + diuron, os tempos 1 e 2 nāo apresentaram diferenças significativas.

Essas diferenças podem ser confirmadas pelas Tabelas 43 à 50, em apêndice, que mostram essas respostas através de suas médias pelo teste de TUKEY para médias de tempo dentro de cada tratamento do fator tratamento.

Dada a importância que assumem os defensivos agrícolas no processo produtivo, sugere-se estudos quantitativos e qualitativos do fracionamento da matéria 
orgânica do solo, para se verificar em verticalidade, possiveis efeitos nāo detectados pela variável evoluçāo de $\mathrm{CO}_{2}$, da atividade microbiana heterotrófica do solo, bem como estudos enzimáticos. 


\section{CONCLUSŌES}

A partir das análises e interpretaçōes dos resultados obtidos, considerando-se as condiçōes edafo-climáticas próprias do local onde o experimento foi conduzido, sāo permitidas as seguintes conclusōes:

1 - Após 13 anos de aplicaçōes anuais dos herbicidas terbacil, simazine, dichlobenil, diuron, bromacil e bromacil + diuron, o impacto provocado por esses produtos parece ser semelhante ao provocado por capinas manuais normais à cultura de citros, objetivando o controle de plantas daninhas.

2- As aplicaçōes de adubos NPK, normais à conduçāo da cultura, realizadas no campo experimental em ótimas condiçōes de umidade, seguida de estiagem nos meses subsequentes, foram as causas da reduçāo da colonizaçāo micorrízica das raízes de citros no tempo, uma vez que, nenhuma outra razāo tenha se apresentado como promotora desse efeito.

3 - O impacto mostrado no número de esporos MVA da regiāo de desenvolvimento das raízes do citros, pelos tratamentos herbicidas terbacil, simazine, dichlobenil, diuron, bromacil e bromacil + diuron, pode ser considerado semelhante ao apresentado pelo sistema de capina manual utilizado na conduçāo da cultura.

4 - O efeito da adubaçāo NPK em ótimas condiçōes de umidade seguida de estiagem, de alguma forma, favoreceu a esporulaçāo dos fungos micorrízicos, 
verificado através do aumento do número de esporos aos 60 dias após aplicação em relação à primeira amostragem.

5 - Os herbicidas terbacil, simazine, dichlobenil, diuron, bromacil e bromacil + diuron, atuaram como agentes moderadores ou estabilizadores da atividade microbiana heterotrófica do solo. Os niveis de evoluçāo de $\mathrm{CO}_{\mathrm{g}}$ foram semelhantes para os herbicidas durante todos os tempos estudados.

6 - Os efeitos apresentados pelos herbicidas estudados, podem ser considerados como não prejudiciais para a colonização micorrizica, população de esporos micorrizicos e atividade da microflora heterotrófica do solo, sendo que para esta última variável pode inclusive ser considerado benéfico, uma vez que manteve a sua atividade, aparentemente estável, isto é, em estado de equilíbrio. 


\section{REFERÊNCIAS BIBLIOGRÁFICAS}

ABBOT, L.K. \& ROBSON, A.D. The distribuition and abundance of vesiculararbuscular endophytes in some western Australian soils. Australian Journal of Botany Melbourne, 25:515-22. 1977.

ALAA-ELDIN, M.N.; MAHMOUD, S.A.Z.; MAKAWI, A.; ABDEL-NASSER, M. \& HERZALLAH, N.A. Effect of pre-emergence application of some herbicides on nodulation, nitrogen fixation and growth of soybean. Pesquisa Agropecuária Brasileira, Brasilia, 16(6):833-839, 1981.

ALEXANDER, M. Introduction to Soil Microbiology. 2.ed. New York, John Wiley \& Sons, 1977. $467 \mathrm{p}$.

ALEXANDER, M. Persistence and biological reactions of pesticides in soils. Soil Science of America Proceeding. 29(1):1-7, 1965.

ALLEN, E.B. \& ALLEN, M.F. Natural re-establishment of vesicular-arbuscular mycorrhize following stripmine reclamation in Wyoming. Journal of Applied Ecology, London, 17:139-47, 1980.

AMAKIRI, M.A. Effect of herbicides on microbial populations and activities in soils under teak (Tectona grandis L.f.) plantation. East, African Agricultural and Forestry Journal. 42(4):420-426, 1977. 
ANDERSON, J.P.E. Herbicide degradation in soil: Influence of microbial Biomass. Soil Biol. Biochem., 16(5):483-489, 1984.

ANDERSON, P.W. Weed Science: principles. New York, West Publishing, Co., 1977. $598 \mathrm{p}$.

ANDERSON, J.R. Pesticide effects on non-target soil microorganisms. Pest. microbiol.:313-533, 1978.

ANDERSON, R.C.; LIBERTA, A.E.; DICKMAN, L.A.; KATZ, A.J. Spatial variation vesicular-arbuscular mycorrhiza spore density. Bulletin of the Torrey Botanical Club, New York, 110:519-25, 1983.

ANTUNES, V. Crescimento do Limāo Cravo (Citrus limonia Osbeck) sob influência da inoculaçāo com fungo micorrízico vesículo-arbuscular e da aplicaçāo de fósforo. Piracicaba, 1987. 99 p. (Tese de Mestrado-Escola Superior de Agricultura "Luiz de Queiroz"/USP).

ANTUNES, V. e CARDOSO, E.J.B.N. Influência de diferentes fontes de fósforo na eficiência de associação micorrízica vesico-arbuscular em porta-enxerto de citros. In: REUNIĀO BRASILEIRA SOBRE MICORRIZA, 2, São Paulo, 1987. Programa e resumos... São Paulo, USP, 1987. p. 34.

ATLAS, R.M. \& BARTHA, R. Microbial ecology: fundamentals and applications. Reading, Mass., Addivon-Wesley, 1981. 559 p.

$A U$, F.H.F. Effect of ethanol and certain other selective herbicide son microbial activity in six different soils. Diss. Abst. B., 28(9):3795-6, 1968.

AUDUS, L.J. Herbicides and the soil. Oxford, Blackwell, p.1-19, 1960. 
AUDUS, L.J. The Physiology and Biochemistry of herbicides. New York and London, Academic Press, p. 163-206. 1964.

BAKALIVANOV, D. \& LALOVA, M. Effect of herbicides alachlor and atrazine on soil microflora of chernozem-smolnitza soils. Pochvozn Agrokhim. Bulgaria, 14(1), 82 8, 1979. (Abstract)

BALOTA, E.L. Flutuaçāo Sazonal de fungos micorrízicos vesículo-arbusculares no cafeeiro (Coffea arabica L.). Piracicaba, 1989. 145 p. (Tese de Mestrado Escola Superior de Agricultura "Luiz de Queiroz"/USP).

BARBOSA, V. Efeitos de alguns herbicidas sobre propriedades de um Latossol Vermelho Escuro fase arenosa, série Santa Teresa. Jaboticabal, 1981. 57 p. (Trabalho de Graduação-Faculdade de Ciências Agrárias e Veterinárias, Campus de Jaboticabal).

BAYLIS, G.T.S. Host treatment and spore production by Endogone. New Zealand Journal of Botany, Wellington, Z:173-4, 1969.

BELLINCK, C.; BATISTIC, L.; MAYAUDON, J. Degradation de 1'acid 2,4dichlorophenoxyacetique dans les sols. Rev. Ecol. Biol. Sol., 16(2):161-8, 1979.

BELLINCK, C. \& MAYAUDON, J. Influence du phenmediphane et dérives sur l'activitè biologique et le nombre de microorganismes des sols frais. Rev. Ecol. Biol. Sol. 15(4):435-44, 1978.

BENTHLENFALVAY, G.J. \& PACOSVSKY, R.S. Light effects in mycorrhizal soybeans. Plant Physiology, Lancaster, 73:969-72, 1982.

BIERMANN, B. \& LINDERMAN, R.G. Quantifying vesicular-arbuscular mycorrhizal: a proposes method to wards standardization. New phytol., 88:63-67, 1981 
BLACK, R. \& TINKER, P.B. The development of endomycorrhizal root systems. IIEffect of agronomic factors and soil conditions on the development of vesiculararbuscular mycorrhizal infection in barley and the endophyte spore density. New Phytologist, Oxford, 83:401-13, 1979.

BLANCO, H.G. Biologia das plantas daninhas - Competiçāo de plantas daninhas brasileiras. In: Controle Integrado de Plantas Daninhas, São Paulo, CREA, 1982. $148 \mathrm{p}$.

BLANCO, H.G. \& OLIVEIRA, D.A. Estudos dos efeitos da época de controle do mato sobre a produção de citros e a composiçāo da flora daninha. Arquivo Instituto de Biologia. 45:25-36, 1978.

BOLGIANO, N.C.; SAFIR, G.R.; WARNCKE, D.D. Mycorrhizal infection and growth of onion in the field in relation to phosphorus and water availability. Journal of the América Society Horticulture Science, New York, 108:819-25, 1983.

BONONI, V.L.R. \& TRUFEM, S.F.B. Endomicorrizas vesiculo-arbusculares do cerrado da reserva biológica de Moji-Guaçu, SP. Brasil. Rickia, Sāo Paulo, 10:55-84, 1983.

BONONI, V.L.R.; BARBOSA, L.M.; VIRIATO, A. Micorrizas vesículo-arbusculares em amendoim e em plantas invasoras da cultura. Hoehnea, São Paulo, 15:1-9, 1988.

BOWEN, G.D. Mycorrhizal roles in tropical plants and ecosystems. In: MIKOLA, P. ed. Tropical Mycorrhiza Research, Oxford, Oxford University Press, 1980. cap.21. p. $165-90$.

BREAZEALE, F.H. \& CAMPER, N.D. Bacterial, fungal and actinomycete population in soils receiving repeated application of 2,4 Dichlorophenoxyacetic acid and trifluralin. Appl. Microbiol., 19:399, 1970. 
BROWN, R.W.; SCHULTZ, R.C. \& NORMANIK, P.P. Response of vesiculararbuscular endomycorrhizal sweetgum seedling to three nitrogen fertilizers. Forest Science, Washington, $\underline{27}(2): 413-20,1981$.

CAETANO, A.A. Herbicidas em Citros. In: RODRIGUEZ, O. \& VIÉGAS, F. Citricultura Brasileira, Campinas, 1980. vol. II. p. 447. Fundaçāo Cargill.

CALDEIRA, S.F.; CHAVES, M.G. e ZAMBOLIN, L. Associaçāo de micorriza vesicular-arbuscular com café. limāo-rosa e capim gordura. Pesquisa Agropecuária brasileira, Brasilia, 18(3):223-8, 1983.

CAMPOS, J.S. Cultura dos Citros. Campinas, CATI - Coordenadoria de Assitência Técnica Integral, 1976. $100 \mathrm{p}$.

CARDOSO, E.J.B.N. Biotecnologia do solo; as micorrizas. Notícias da Escola Superior de Agricultura "Luiz de Queiroz", Piracicaba, $\underline{3}(14): 5,1990$.

CARDOSO, E.J.B.N.; ANTUNES, V.; SILVEIRA, A.P.D. e OLIVEIRA, M.H.A. Eficiência de fungos micorrizicos vesículo-arbusculares em porta-enxertos de citros. Revista Brasileira de Ciência do Solo, Campinas, 10(1):25-30, 1986.

CHAHAL, D.S.; BANDS, I.S.; CHOPRA, S.L. Degradation of alachlor (2-cloroN(methoxymetil)-2'6'-diethylacetanilide) by soil fungi. Plant and Soil, 45:689-92, 1976. (Short Communication).

CHILVERS, M.T. e DAFT, M.F.J. Mycorrhizas of the lilifilorae. II Mycorrhiza formation and incidence of root hairs in field grow Narcisus L., Tulipa L. and Crocus L. cultivars. The New Phytologist, London, 89:247-61, 1981.

COLE, M.A. Effect of long-term atrazine application on soil microbial activity. Weed Science 24(5):473-476, 1976. 
COLOZZI-FILHO, A. \& SIQUEIRA, J.O. Micorrizas vesículo-arbusculares em mudas de cafeeiro. I. Efeitos de Gigaspora margarita e adubaçāo fosfatada no crescimento e nutrição. Revista Brasileira de Ciência do Solo Campinas, 10(3):199-205, 1986.

COOPER, K.M. Growth responses to the formation of endotrophic mycorrhizas in Solanum, Leptospermum, and New Zeland Ferns. In: SANDERS, F.E.; MOSSE, B. \& STINKER, P.B. Endomycorrhizas, London, Academic Press, 1975. p. 391-407.

COX, G.; SANDERS, F.E.; TINKER, P.B. e WILD, J.A. Ultrastructural evidence relating to host endophyte transfer in a vesicular-arbuscular mycorrhiza. In: SANDERS, F.E.; MOSSE, B. e TINKER, P.B. Endomycorrhizas, London, Academic Press, 1975. p.297-306.

CULLIMORE, D.R. \& MCCANN, A.E. Influence of four herbicides on the algal flora of a prairie soil. Plant and Soil, 46(3):499-510, 1977.

CRUZ, L.S.P.; LEIDERMAN, L. e von HERTWIG, K. Estudo da açāo de algumas diazinas e tetrazinas no controle de plantas daninhas em pomar de laranjeiras "Natal", durante quatro anos. In: XII Seminário Brasileiro de Herbicidas e Ervas Daninhas, Fortaleza, Ceará. Resumos, 1978. p. 19-20.

DAFT, M.J.; HACSKAYLO, E.; NICOLSON, T.H. Arbuscular mycorrhizas in plants colonising coal spoils in Scotland and Pennsylvania. In: SANDERS, F.E.; MOSSE, B.; TONKER, P.B. eds., Endomycorrhizas, London, Academic press, 1975. p. 561 80.

DANIELS, B.A. \& TRAPPE, J.M. Factors affecting spore germination of the VAM fungus, Glomus epigaeus. Mycologia, New York, 72:456-71, 1980. 
DANIELS, B.A. e MENGE, J.A. Evaluation of the commercial potencial of the vesicular-arbuscular mycorrhizal fungus, Glomus epigaeus. The new Phytologist, London, 87:345-54, 1981.

DAVET, P. Effects de quelques pesticides sur la colonisation d'un substrat par le Trichoderma harzianum rifai en presence des autres champignons du sol. Soil Biol. Biochem., 13(6):513-517, 1981.

DAVIES, H.A. \& MARSH, J.A.P. The effect of herbicides on respiration and transformation of nitrogen in two soils. II. Dalapon, pyrazone and trifluralin. Weed Research, 17:373-378, 1977.

DAVIS, D.E.; PILLAI, C.G.P. \& TRUELOVE, B. Effects of prometryn, diuron, fluometuron and MSMA on Chlorella and two fungi. Weed Science, 24(6):587-593, nov. 1976.

DESHMUKH, V.A. \& SHRIKHANDE, J.G. Effect of pre and post-emergence treatment of herbicides on soil microflora and tow microbial processe. J. Indian Soc. Soil Sci., 22(1):36-42, 1974.

DEUBER, R. \& FORSTER, R. Influência do EPTC na nodulaçāo natural de feijāo (Phaseolus vulgaris L.). Planta Daninha, 1(2):38-43, 1978.

DOMSCH, K.H. \& PAUL, W. Simulation and experimental analysis of the influence of herbicides on soil nitrification. Arch, Mikrobiol., 97:283-301, 1974.

DONADIO, L.C.; LEITĀO FILHO, H.F. \& ARANHA, C. Resultados preliminares do coroamento de plantas cítricas com herbicidas em solo arenoso. In: Congresso Brasileiro de Fruticultura, I, Campinas - SP. Anais, 1971. p. 305-312. 